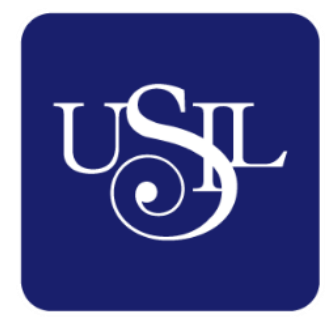

UNIVERSIDAD

SAN IGNACIO

DE LOYOLA

ESCUELA DE POSTGRADO

Maestría en Diseño Gráfico

\title{
DISEÑO DE HISTORIAS ILUSTRADAS CONTRA LA DISCRIMINACIÓN POR EDADISMO PARA EVITAR EL AISLAMIENTO SOCIAL
}

Tesis para optar el grado de Maestro en Diseño Gráfico

\section{DAYRA LINA ELIZABETH ITA SARRIN}

\author{
Asesor: \\ Mg. Leila Susan Munive Loza
}

Lima - Perú

2020 


\section{Dedicatoria}

A todos mis seres queridos, por darme la motivación necesaria para seguir adelante en mi formación profesional. Y a cada persona mayor que espera ser escuchada, valorada y amada. 


\section{Agradecimientos}

Gracias a Dios por brindarme salud. A mi padre, Juan Ita y mi madre, Lina Sarrin, por su constante apoyo incondicional. A mi hermana, Bianca Ita, una excelente ilustradora que me orientó y ayudó cuando lo necesité. A mi hermano, Eder Ita, por brindarme ideas pese al poco tiempo que tenía. A mi enamorado, Mariano Vargas, por tomarse el tiempo para ser camarógrafo, corrector de estilo, lector y hasta psicólogo, gracias por escucharme cada vez que tenía un bloqueo. A mi asesora, Leila Munive, por su constante apoyo, paciencia y asesoramiento. A todos los profesores de la maestría que me transmitieron sus enseñanzas. A mis mentores, Juan Tanta y Osvaldo Gaona, por el tiempo que han dedicado a mi proyecto, es un honor y orgullo tener su opinión y aceptación. Y a todas las personas mayores que me dedicaron un poco de su valioso tiempo para sentarse a conversar conmigo. 


\section{Resumen}

Según el Instituto Nacional de Estadística e Informática (INEI, 2017), en los últimos 45 años, la población de 60 años a más se ha triplicado. Esta cifra evidencia un incremento de longevidad, debido a los grandes cambios demográficos experimentados en las últimas décadas. Por lo que ya es un hecho que el país afronta un proceso de envejecimiento poblacional.

La presente investigación busca dejar en evidencia al edadismo, una de las tres grandes formas de discriminación de nuestra sociedad (Lozada, 2004), detrás del racismo y sexismo, es un problema social que afecta a todas las clases sociales. Por ello mediante las herramientas del diseño gráfico como es la ilustración se crea el proyecto "Tesoros de vida" que busca promover la valoración de la población mayor a través de historias de personas mayores, para su reconocimiento bajo el concepto de tesoro de la sociedad. Es así que se construye una imagen positiva de la vejez, revalorizando la experiencia, el esfuerzo y las habilidades de aquellos que poseen los conocimientos de toda una vida.

Urge que todos los que tienen un rol desde diferentes escenarios se pronuncien y actúen en beneficio de las personas mayores. Por lo tanto, a través del diseño gráfico se puede construir una sociedad para todas las edades.

Palabras Clave: historias ilustradas, discriminación, edadismo, aislamiento social 


\begin{abstract}
According to the National Institute of Statistics and Informatics (2017), in the last 45 years, population aged 60 and over has tripled. This figure shows an increase in longevity, due to the great demographic changes faced in the last decades. So, it is already a fact that the country is facing a process of population aging.
\end{abstract}

This research aims to expose ageism, one of the three great forms of discrimination in our society (Lozada, 2004), behind racism and sexism. This is a social problem that affects all social classes. For this reason, through graphic design tools such as illustration, the "Treasures of Life" project was created, with the main objective to promote the appreciation of the elderly population through stories of the elderly, in order to recognize it under the concept of society's treasure. As a consequence, a positive image of old age is built, revaluing the experience, effort and skills of people who have the knowledge of a lifetime.

It is urgent that all those who have a role from different scenarios speak out and act for the benefit of older people. Therefore, through graphic design, a society for all ages can be built.

Key words: Illustrated stories, discrimination, ageism, social isolation 


\section{Tabla de Contenidos}

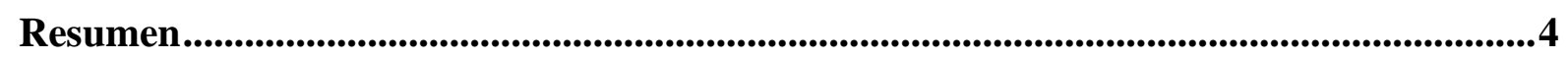

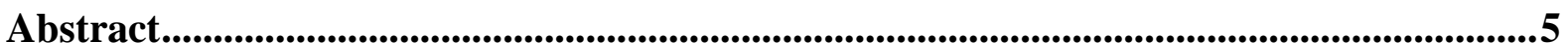

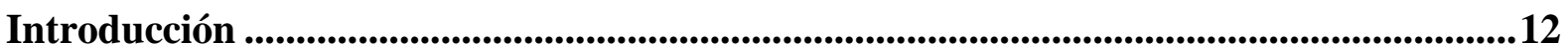

2.1. Descripción del Problema ............................................................................ 13

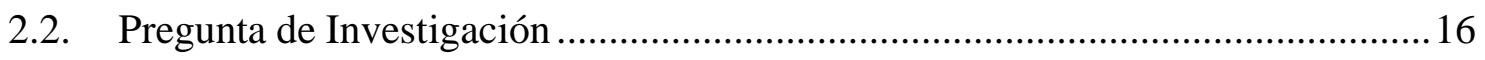

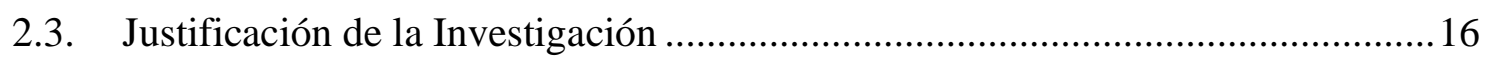

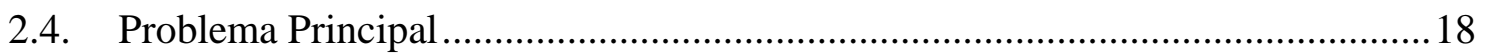

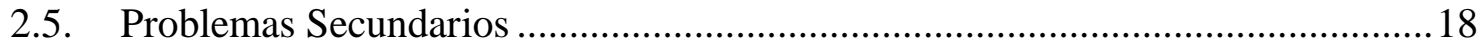

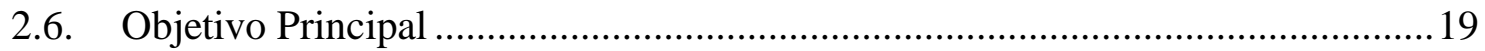

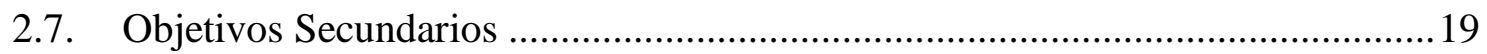

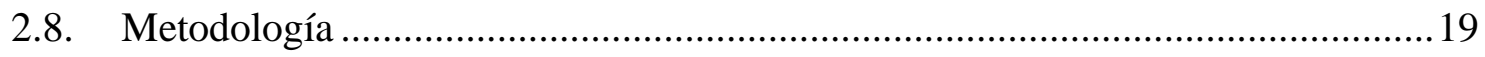

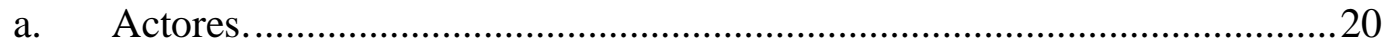

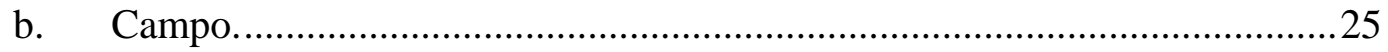

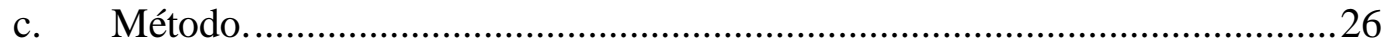

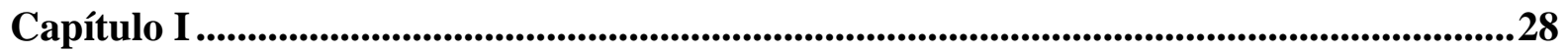

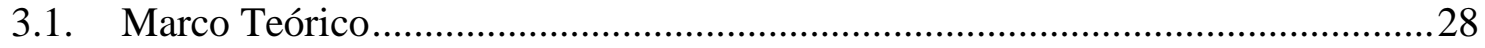

A. La vejez y la persona adulta mayor. ...................................................28

a. Concepto de vejez y envejecimiento................................................28

b. Definición de persona adulta mayor. ...................................................33

c. La imagen negativa de la vejez. ...................................................... 34

d. Estereotipos y prejuicios de la vejez............................................... 35

e. Influencia de los medios de comunicación y la publicidad....................37

f. Situación de las PAM en el Perú. ............................................................39

g. Marco normativo y programas a favor de las PAM..............................39

h. Autopercepción del Adulto mayor.......................................................41

B. Discriminación, edadismo y el aislamiento social...................................42

a. Concepto de discriminación...........................................................42

b. Tipos de discriminación.................................................................4 


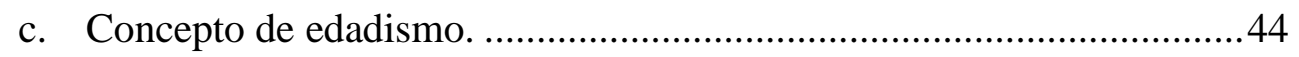

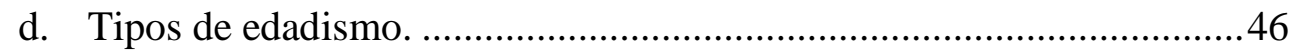

e. Aspectos cognitivos, afectivos y conductuales del edadismo...............46

f. El aislamiento social como consecuencia de la discriminación. ............48

C. Diseño gráfico y diseño editorial...........................................................49

a. Definición de diseño y diseño gráfico................................................50

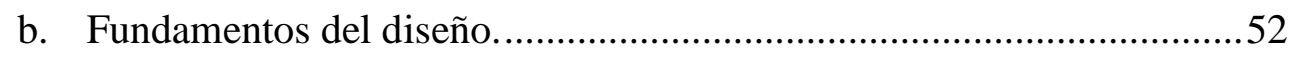

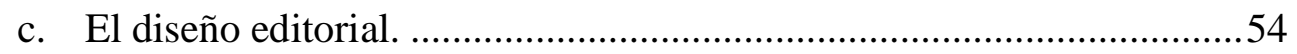

d. Elementos que componen una pieza editorial.....................................55

e. Productos editoriales. .......................................................................58

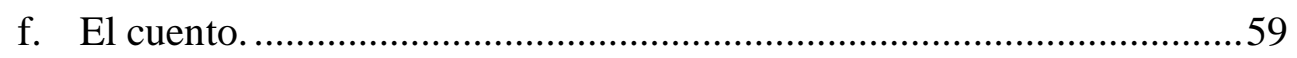

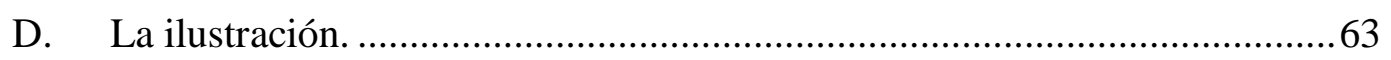

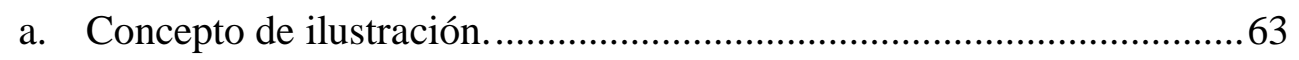

b. Características de la ilustración. ........................................................65

c. La ilustración y su potencial comunicacional. .....................................66

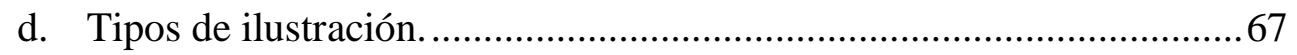

e. Técnicas de ilustración...................................................................69

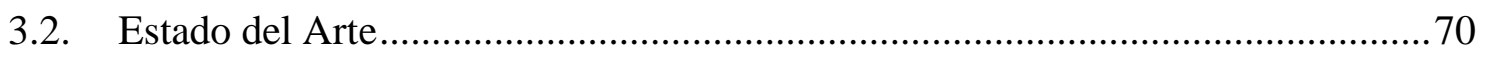

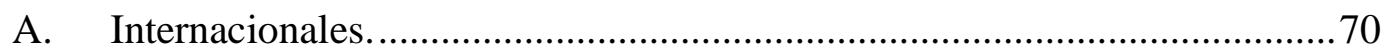

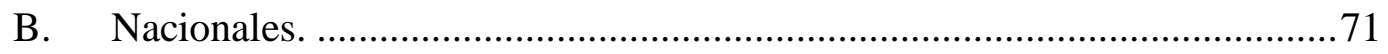

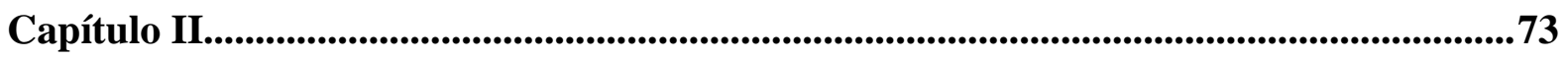

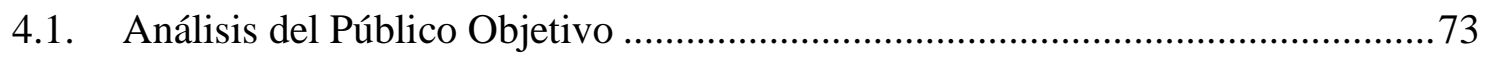

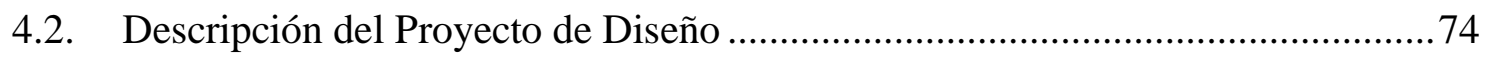

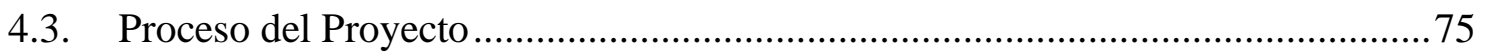

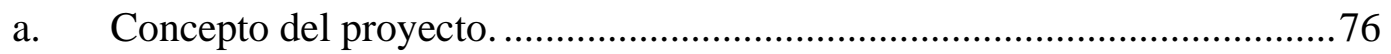

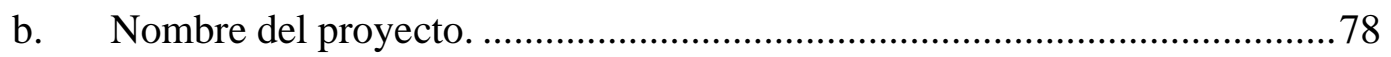

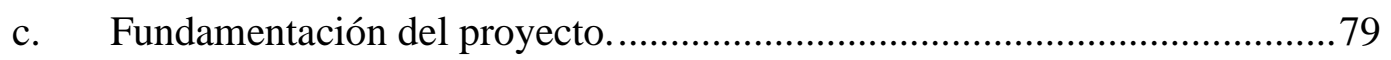

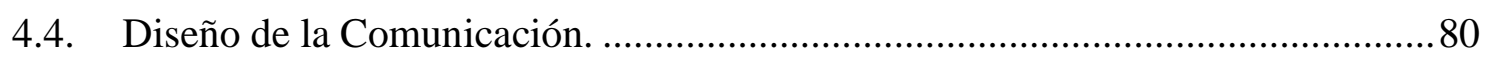

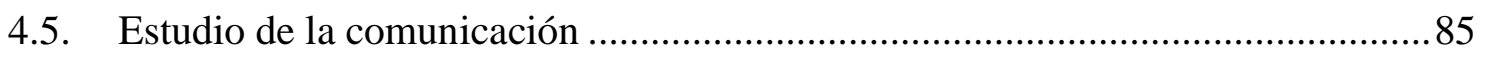

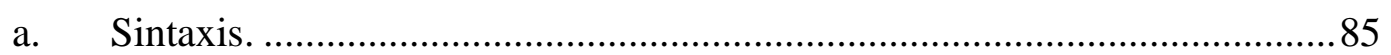

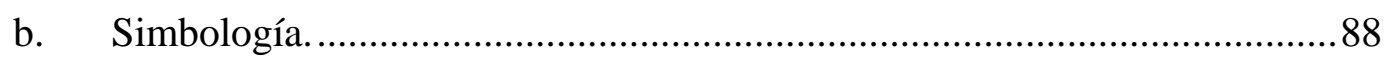




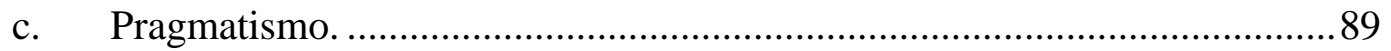

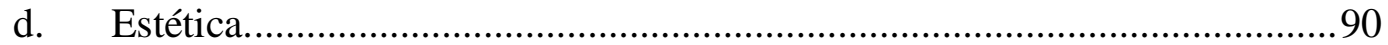

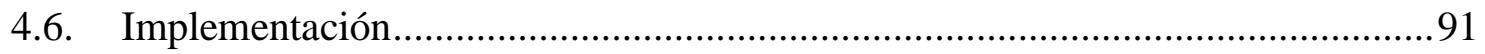

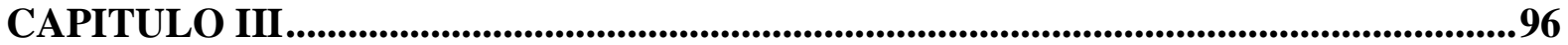

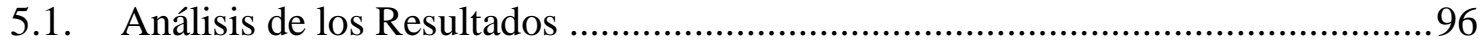

A. Aplicación del proyecto.........................................................................

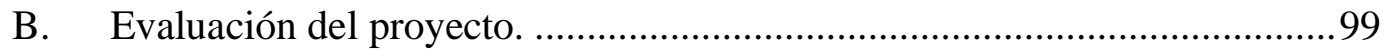

C. Registro de implementación. ................................................................ 101

D. Documentos que acreditan el proyecto ................................................109

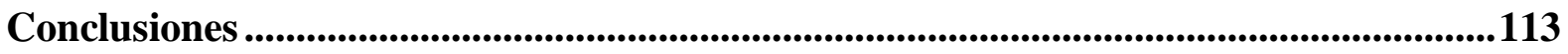

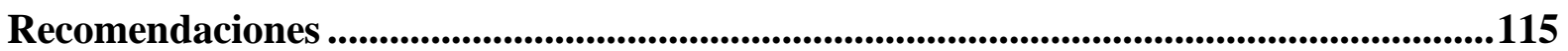

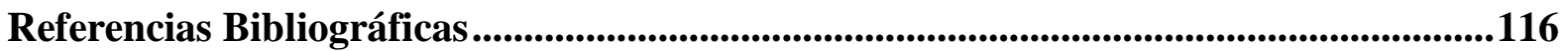

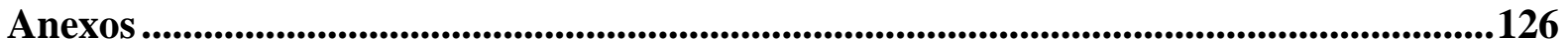

Anexo 1. Cuestionario realizado a la comunidad ......................................................... 126

Anexo 2. Lista de preguntas de la entrevista realizada a las PAM..............................128

Anexo 3. Lista de preguntas de la entrevista a la comunidad ....................................129

Anexo 4. Expresiones que se relaciona con las personas mayores. .............................130

Anexo 5. Situación de la población adulta mayor en el Perú ........................................131

Anexo 6. Marco Normativo Internacional ................................................................132

Anexo 7. Marco Normativo Nacional …................................................................... 134

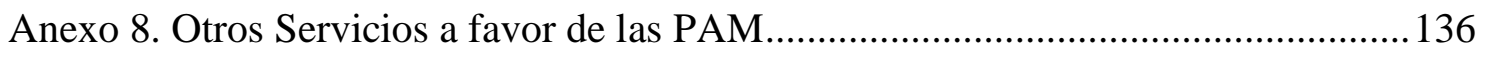

Anexo 9. Resultados Cuantitativos - Cuestionario realizado a la comunidad.............137

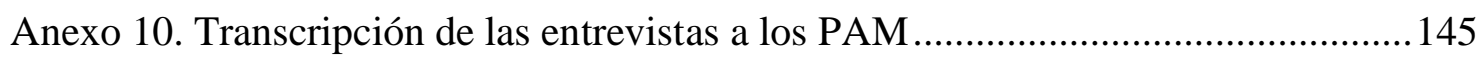

Anexo 11. Transcripción de las entrevistas a la comunidad ....................................153 


\section{Listado de Figuras}

Figura 1. Pirámide de la población en 1950 y 2019

$\begin{array}{lr}\text { Figura 2. Marco conceptual } & 18\end{array}$

$\begin{array}{lr}\text { Figura 3. Mapa de actores } & 20\end{array}$

Figura 4. Metodología de la Investigación 26

$\begin{array}{ll}\text { Figura 5. Públicos objetivos } & 73\end{array}$

$\begin{array}{ll}\text { Figura 6. Concepto del proyecto } & 76\end{array}$

Figura 7. Análisis Conceptual Revaloración del Tesoro 77

Figura 8. MoodBoard del concepto "Revaloración del Tesoro" 78

Figura 9. Fases del proyecto

Figura 10. Logo del proyecto 86

Figura 11. Logotipo en positivo y negativo 86

$\begin{array}{ll}\text { Figura 12. Logotipo a una tinta. } & 87\end{array}$

$\begin{array}{ll}\text { Figura 13. Paleta tipográfica } & 87\end{array}$

Figura 14. Paleta de colores 88

Figura 15. Símbolo gráfico $\quad 89$

$\begin{array}{ll}\text { Figura 16. Portada del cuento } & 90\end{array}$

$\begin{array}{ll}\text { Figura 17. Estilo gráfico del cuento } & 91\end{array}$

Figura 18. Calendario editorial 92

Figura 19. Invitación a la presentación del cuento 93

Figura 20. Pieza principal: cuento. 94

$\begin{array}{lr}\text { Figura 21. Ruta recorrida } & 102\end{array}$

$\begin{array}{ll}\text { Figura 22. Entrevista a cuatro personas mayores } & 102\end{array}$

$\begin{array}{ll}\text { Figura 23. Guión de la historia seleccionada y escaleta } & 103\end{array}$

$\begin{array}{ll}\text { Figura 24. Machote del cuento } & 103\end{array}$

$\begin{array}{ll}\text { Figura 25. Ilustración a mano alzada } & 104\end{array}$

$\begin{array}{ll}\text { Figura 26. Colorización de las ilustraciones } & 104\end{array}$

$\begin{array}{ll}\text { Figura 27. Diseño y diagramación del cuento } & 105\end{array}$

$\begin{array}{ll}\text { Figura 28. Instagram del proyecto } & 105\end{array}$

Figura 29. Historias publicadas en Instagram 106 
$\begin{array}{ll}\text { Figura 30. Post publicados en Instagram } & 106\end{array}$

$\begin{array}{ll}\text { Figura 31. Publicación de la invitación por Instagram } & 107\end{array}$

Figura 32. Publicación de la invitación por WhatsApp y número de vistos 107

$\begin{array}{ll}\text { Figura 33. Presentación del proyecto social } & 108\end{array}$

$\begin{array}{ll}\text { Figura 34. Participantes de la presentación virtual del cuento } & 108\end{array}$

$\begin{array}{ll}\text { Figura 35. Lectura del cuento } & 109\end{array}$

$\begin{array}{ll}\text { Figura 36. Comentarios de los participantes } & 109\end{array}$

$\begin{array}{ll}\text { Figura 37. Carta de evaluación de pares } \mathrm{N}^{\circ} 1 & 110\end{array}$

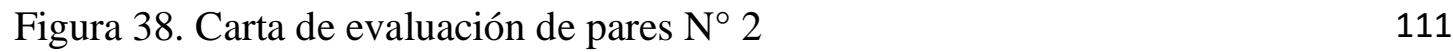




\section{Listado de Tablas}

Tabla 1. Expresiones anteriores y posteriores a la Convención

Interamericana de Protección de los Derechos de las Personas

Mayores

Tabla 2. Análisis de la imagen que se proyecta de las personas mayores a través de medios de comunicación.

Tabla 3. Programas nacionales a favor de las PAM

Tabla 4. Tipos de Edadismo

Tabla 5. Relación de aspectos cognitivos, afectivos y conductuales

Tabla 6. Clasificación de cuentos 


\section{Introducción}

La presente investigación busca evidenciar cómo la sociedad incurre en edadismo. Un término no muy popular que hace referencia a los estereotipos, prejuicios y actitudes negativas contra las personas, única y exclusivamente, debido a su edad. Siendo esta discriminación el principal obstáculo que enfrentan las personas mayores en su vida cotidiana. Ello logra que sean marginados y excluidos de su entorno cercano, e inclusive, viéndose afectado su bienestar social.

De acuerdo con Butler citado en Lozada (2004), el edadismo es una de las tres grandes formas de discriminación de nuestra sociedad, después del racismo y sexismo. Un problema social que se viene dando en todas las sociedades, y quizá es el prejuicio más normalizado que afecta negativamente a las personas de edad, (entendiéndose a las personas mayores de 60 años) conduciéndolos a un aislamiento social, manifestado a través de la carencia de relaciones sociales. En relación a ello, Géne et al (2016, p. 605) definen al aislamiento social como "la situación objetiva de tener mínimos contactos con otras personas, bien sean familiares o amigos”. Así mismo, Lacida citado en Navarro (2017), manifiesta cómo el individuo es un ser sociable por naturaleza, por lo que requiere estar siempre acompañado. De tal manera que, esta situación en la persona mayor es un factor de riesgo capaz de desencadenar consecuencias a nivel mental, emocional y, en algunos casos, físicas.

Considerando las investigaciones previas, se estimó que la realización de la presente se incline por una metodología que evidencie el problema de manera objetiva y veraz. Por lo tanto, se optó por un enfoque cualitativo experimental. Así mismo, se seleccionó a los actores involucrados en la problemática de investigación. Se detalló los instrumentos más adecuados para la recolección de datos en el estudio, siendo la entrevista aplicada a los actores discriminados y discriminantes, que tendrán el acrecentamiento por las encuestas realizadas a ambas partes para poder tener una visión global del problema. 
Como campo de estudio se eligió el distrito de Carabayllo, uno de los diez distritos más poblados de Lima Metropolitana (Compañía Peruana de Estudios de Mercado y Opinión Pública [CPI], 2019). Este sector cuenta con un número muy significativo de clubs o asociaciones para personas mayores. A pesar de ello, se evidencia ciertas actitudes discriminatorias que influyen en el desarrollo social de este grupo de personas del distrito.

A través del proyecto "Tesoros de vida", se pretende promover la valoración de la población mayor, a través de una serie de ilustraciones que narren y transmitan las historias de vida recogidas de personas mayores. Esto, para otorgarles el rol social que tienen las Personas Adultas Mayores (en adelante PAM), como transmisores de tradiciones y valores intergeneracionales con un legado para compartir y difundir; como tesoro de la sociedad.

Tomando en cuenta lo anterior, se permitirá cambiar la imagen negativa de la vejez, revalorizando la experiencia, el esfuerzo y las habilidades de aquellos que poseen los conocimientos de toda una vida. También, se transmitirá una imagen positiva de la vejez reflejando a las personas mayores como sujetos activos, participativos y fundamentales para nuestra sociedad como patrimonio inmaterial. Por ello, se plantea aplicar las ilustraciones en una pieza editorial que pueda ser transmitida al público para concientizar sobre la discriminación por edadismo y revalorar a las personas mayores. Esto conllevará a cambiar las preconcepciones que se tienen sobre estas personas.

\subsection{Descripción del Problema}

Al hablar del término, adultos mayores, lo más eventual que se puede recordar es una persona de cabello cano, encorvada y con dificultades para caminar. Así también, lo visionamos viendo programas televisivos, tomando una siesta en algún sillón, o simplemente sin alguna actividad productiva. La falta de actividades genera un desperdicio de la sabiduría y conocimiento que una persona adulta tiene, ya sea por los años vividos o la experiencia acumulada. Un adulto mayor resulta ser un tesoro valioso y muchas veces no es considerado 
como tal, sino más bien, es tratado como una persona que no aporta ni apoya en las actividades diarias generando que sea vulnerable ante la discriminación.

Según el Instituto Nacional de Estadística e Informática (INEI, 2019) en Perú “se considera como personas adultas mayores a la población de 60 y más años de edad, en concordancia con el criterio adoptado por las Naciones Unidas" (p. 1). Por lo tanto, hoy en día suman más de 3 millones de personas adultas mayores. Así mismo, en su último informe técnico sobre la Situación de la Población Adulta Mayor, describen cómo las personas mayores conforman el 12,4\% de la población peruana, en comparación con el 5.7\% de la población adulta mayor de 1950 (INEI, 2019).
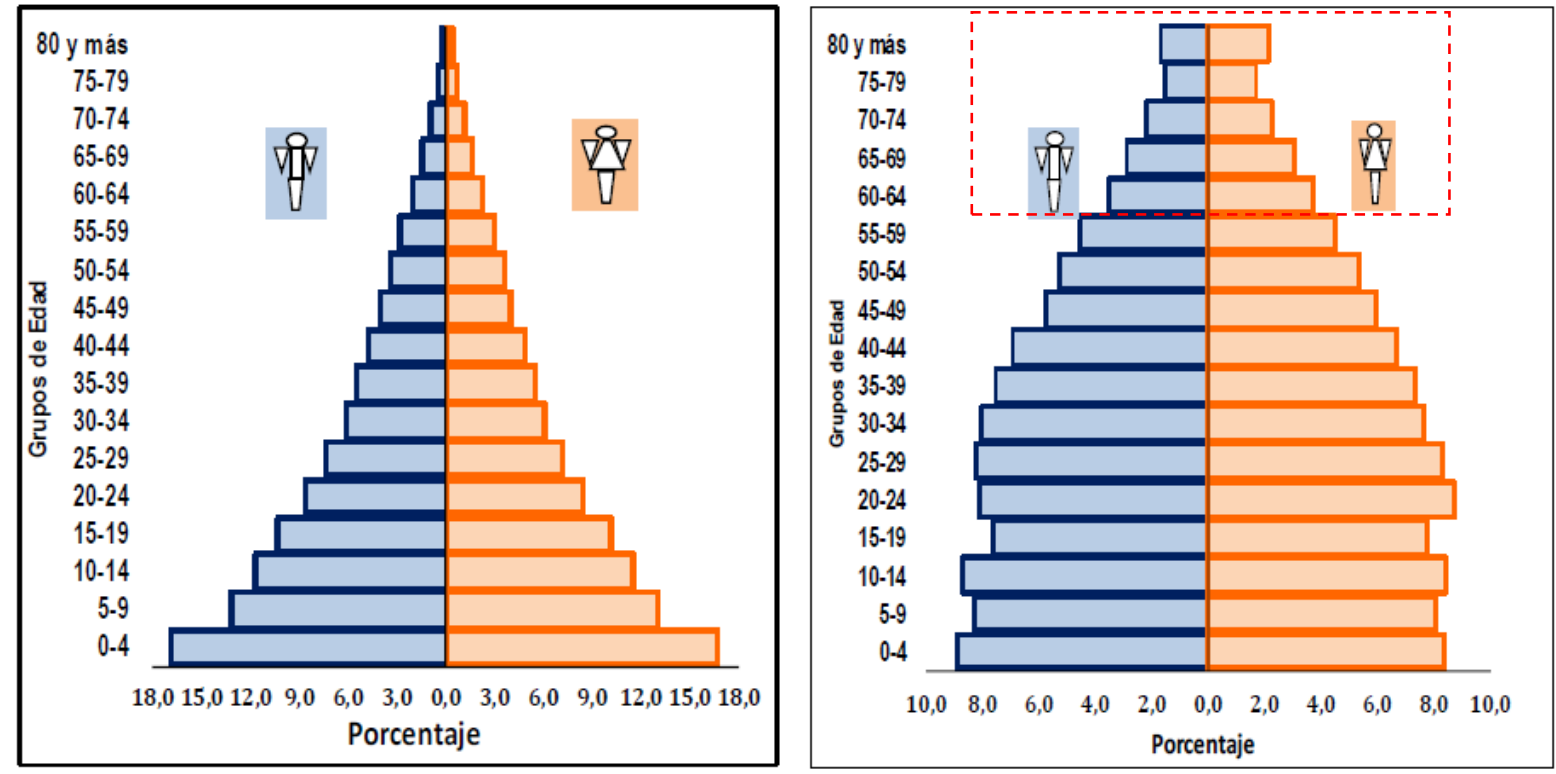

Figura 1. Pirámide de la población en 1950 y 2019. Tomado de "Informe técnico situación de la población adulta mayor (Informe $\mathrm{N}^{\circ} 3$ )", por el Instituto Nacional de Estadística e Informática (INEI), 2019. Recuperado de https://www.inei.gob.pe/media/MenuRecursivo/boletines/03-informe-tecnico-n03_adultoabr-may-jun2019.pdf

Se puede visualizar en la figura 1, la primera pirámide que evidencia una base ancha con un vértice angosto, mientras que en la segunda se observa una base reducida con un ensanchamiento en los centros, hasta llegar a un vértice de mayor proporción. De tal forma, 
se observa una mayor proporción de población adulta mayor que indica el inicio del proceso de envejecimiento poblacional.

Solo en Lima, la población adulta mayor asciende a más de un millón de personas. En los últimos 45 años, la población de 60 a más años se ha triplicado (INEI, 2017), cifra que evidencia un incremento de la longevidad en la población debido a los grandes cambios demográficos experimentados. De ello, comprendemos que estamos en un proceso de envejecimiento poblacional, situación que nos obliga a tomar medidas ante las desigualdades sociales y la discriminación que sufren las personas adultas mayores.

Dentro del edadismo, se observa una sociedad donde se considera que ser adulto mayor es sinónimo de ser incapaz, una carga tanto para la familia, así como el trabajo y hasta para la sociedad. Donde la vejez es vista como un sinónimo de ignorancia o de una falta de capacidad para pensar, generando que estas personas (adultos mayores) sean ignorados u olvidados, expuestos al maltrato y discriminación por el hecho de alcanzar una edad avanzada.

Un estereotipo equivocado de la sociedad con respecto a las personas mayores es que la imagen de la vejez o del envejecimiento genere discriminación por parte de las personas cercanas a los adultos mayores. Situación que describe el llamado edadismo, como una forma de discriminación poco conocida, que alude al apartamiento de las personas mayores basada en prejuicios y estereotipos respecto a la edad, que afecta a millones de personas adultas mayores en sus vidas cotidianas.

Ser adulto mayor no supone un problema, la vejez no es una enfermedad sino una fase de la vida. Debemos dejar de lado esa percepción inconsciente, donde los cambios que conlleva el envejecimiento son indeseables. Estereotipos que deben cambiarse y pese a, que hoy en día, existen diversas normativas y programas que garantizan el ejercicio de los derechos de las personas mayores sean aplicadas y avaladas, aún no se logra concretar esta práctica en la 
realidad. Aún somos testigos de desempleo, soledad y pérdida de reconocimiento social que sufren estas personas por motivos de la edad.

\subsection{Pregunta de Investigación}

El edadismo es una forma de discriminación que implica actitudes, estereotipos y prejuicios contra las personas según su edad. Esta situación es recurrente en las personas mayores y genera exclusión del mercado laboral, límite de los servicios sociales de la comunidad, sesgo en la imagen presentada en los medios de comunicación como personas frágiles y dependientes, el trato limitante como niños, falta de retención de la información, de salud debilitada, cascarrabias que sólo quieren aburrir con sus historias. Pese a ser un problema globalizado junto con el racismo o el sexismo, es el prejuicio social más normalizado.

De ahí que nos preguntemos ¿Cómo el edadismo limita a las personas mayores en el desarrollo de su vida social?

\subsection{Justificación de la Investigación}

El edadismo no es un problema ajeno en nuestra sociedad, y afecta todas las personas mayores. Considerando que la población mundial tiene un índice de mortalidad decreciente, las personas tienen mayor cantidad de años durante la vejez. Según Gálvez y Ponce (2007 p 12), manifiestan como "el envejecimiento constituye una etapa vital como la niñez, la madurez o la adolescencia, con unas enfermedades características propias y también oportunidades, pero que no tiene necesariamente que asociarse con enfermedad". De tal manera, la vejez es la etapa que tiende a relacionarse con el descanso y meditación, donde las personas pueden lograr las metas que postergaron mientras criaban a sus hijos o desarrollaban su carrera. Sin embargo, es un problema muy notable en nuestra sociedad, que, a pesar de estar cada vez más desarrollada, se equivoca en considerar a las personas mayores como cargas para los demás o pensar que su vida tiene menos valor. 
Los estereotipos y prejuicios establecidos por la sociedad e influenciada por los medios de comunicación y publicidad han hecho que las personas tengan una imagen negativa de la persona mayor. Por ello, tienden a confundir vejez con decadencia y enfermedad, apartándolos de las funciones productivas, de transmisión de experiencias y de la vida social que una persona necesita.

Como manifiesta el Instituto Nacional contra la Discriminación, la Xenofobia y el Racismo (2017), "los estereotipos y prejuicios se construyen, entre otros motivos, como mecanismos de resguardo de unos grupos sociales frente a otros” (p. 31). De tal manera, el número de ancianos ha perdido importancia, ya que se valora más la juventud y los valores asociados a la misma, por lo tanto, son más proclives las personas mayores a la depresión y el aislamiento social.

De tal forma, el presente estudio busca a través del diseño evidenciar cómo la discriminación por edadismo lleva al adulto mayor de la comunidad de Santa Isabel de Carabayllo a aislarse socialmente, y así mismo busca identificar los prejuicios y estereotipos de la sociedad que afecta en la pérdida del reconocimiento social por motivos de edad. Suscitando diversas situaciones cotidianas que lo llevan a tener una autopercepción negativa.

Es de vital importancia que todos, desde diferentes escenarios, se pronuncien y actúen en beneficio de ellos y, por ende, ser capaces de construir una sociedad para todas las edades. Como diseñadores podemos dejar en evidencia este problema ante una sociedad edadista, sobre todo sensibilizarlos para que comprendan que, hasta una acción habitual, simple o hasta inconsciente puede generar edadismo. 


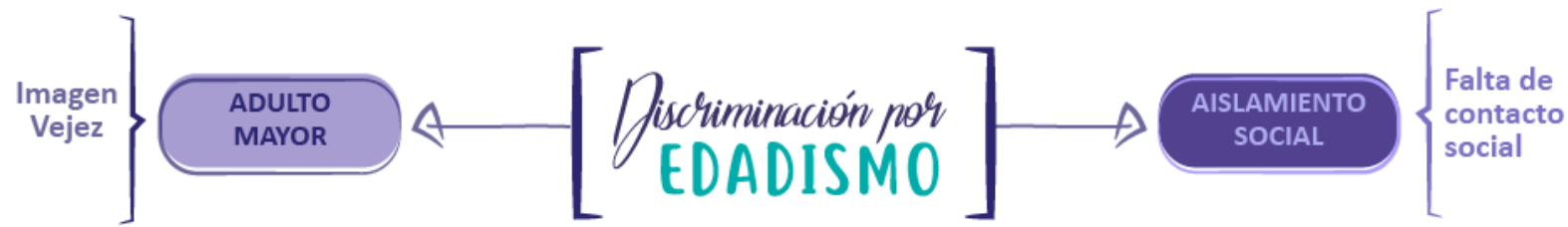

Vejez y envejecimiento

Discriminación

Persona adulta mayor

Tipos de discriminación

La imagen negativa de la vejez

Edadismo

Influencias de comunicación y publicidad

Tipos de edadismo

Situación de las PAM en el Perú

Autopercepción de la persona adulta mayor

Aspectos cognitivos, afectivos y conductuales
del edadismo

El aislamiento social como consecuencia de la discriminación

Figura 2. Marco conceptual. Elaboración propia, 2019.

\subsection{Problema Principal}

¿Cómo la discriminación por edadismo genera un aislamiento social en personas mayores pertenecientes a los sectores económicos C y D en el distrito de Carabayllo de la ciudad de Lima Metropolitana?

\subsection{Problemas Secundarios}

¿Cómo los estereotipos de la discriminación por edadismo generan un aislamiento social en personas mayores pertenecientes a los sectores económicos $\mathrm{C}$ y $\mathrm{D}$ en el distrito de Carabayllo de la ciudad de Lima Metropolitana?

¿Cómo los prejuicios de la discriminación por edadismo generan un aislamiento social en personas mayores pertenecientes a los sectores económicos $\mathrm{C}$ y $\mathrm{D}$ en el distrito de Carabayllo de la ciudad de Lima Metropolitana?

¿Cómo la autopercepción a consecuencia de la discriminación por edadismo genera un aislamiento social en personas mayores pertenecientes a los sectores económicos C y D en el distrito de Carabayllo de la ciudad de Lima Metropolitana? 


\subsection{Objetivo Principal}

Evidenciar la discriminación por edadismo que genera un aislamiento social en personas mayores pertenecientes a los sectores económicos $\mathrm{C}$ y $\mathrm{D}$ en el distrito de Carabayllo de la ciudad de Lima Metropolitana.

\subsection{Objetivos Secundarios}

Informar sobre los estereotipos de la discriminación por edadismo que generan un aislamiento social en personas mayores pertenecientes a los sectores económicos $\mathrm{C}$ y $\mathrm{D}$ en el distrito de Carabayllo de la ciudad de Lima Metropolitana.

Informar sobre los prejuicios de la discriminación por edadismo que generan un aislamiento social en personas mayores pertenecientes a los sectores económicos C y D en el distrito de Carabayllo de la ciudad de Lima Metropolitana.

Dar a conocer la autopercepción a consecuencia de la discriminación por edadismo que generan un aislamiento social en personas mayores pertenecientes a los sectores económicos C y D en el distrito de Carabayllo de la ciudad de Lima Metropolitana.

\subsection{Metodología}

El desarrollo de la presente investigación será a través de un enfoque mixto, Hernández, Fernández y Baptista (2010), sostienen que la meta de dicha investigación es emplear las fuerzas de ambos enfoques para minimizar sus debilidades. De tal manera, se busca que la recolección de datos y análisis cuantitativos sea reforzada por el cualitativo, y así se logre tener una mejor visión de ambos enfoques, de tal manera, la combinación de ambos aporta mejores resultados obtenidos.

El diseño para esta investigación será a través del diseño concurrente, porque se aplicarán ambos métodos cuantitativos y cualitativos. De tal forma, Hernández et al. (2010), refiere que la ejecución concurrente de la recolección de datos se da en diferentes secuencias, sin 
necesidad de ser simultánea, ni se da prioridad a un método o a otro, sino que ambos tienen el mismo peso, cuyo propósito es integrar ambos métodos.

Entonces, la presente investigación está conformada por una serie de métodos, que en una primera instancia a través del enfoque cuantitativo se pretende realizar la recolección de datos con la técnica de la encuesta, por medio de un cuestionario, para obtener una información clara y directa de los principales actores discriminantes.

Para el enfoque cualitativo se pretende realizar una entrevista a cuatro personas mayores para recopilar información relevante sobre la situación que enfrenta. A sí mismo, a través una entrevista a personas de la comunidad se pudo identificar la imagen que tienen de la vejez y hacia el adulto mayor. En ese sentido, se busca tener una visión global de la situación.

\section{a. Actores.}

A continuación, se presenta los actores involucrados en el problema.

\section{Mapa de Actores}

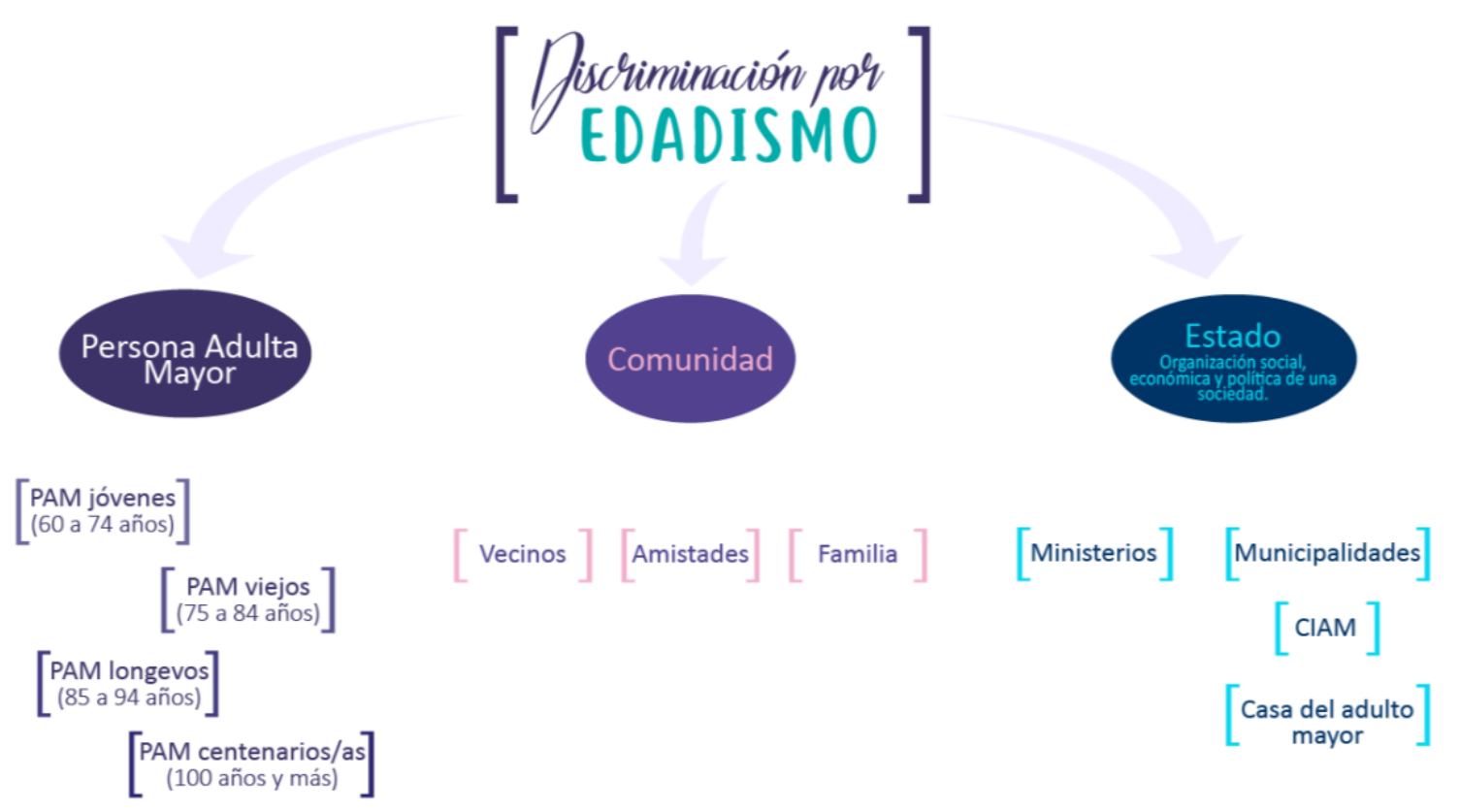

Figura 3. Mapa de actores. Elaboración propia, 2019.

De tal manera, en un ámbito humano encontramos: 


\section{- Persona mayor.}

Es el término que reciben las personas que pertenecen al grupo etario, que comprende, según el artículo 2 de la Ley №30490, “por personas adultas mayores a todas aquellas que tenga 60 o más años”. Por lo general, se les considera persona mayor, sólo por alcanzar este rango de edad, sin embargo, son tildados con términos como "viejos", "ancianos", "personas de la tercera edad", que, habiendo alcanzado la adultez transitan la etapa de la vejez, y que forman parte de la sociedad con su experiencia y sabiduría ganada a través de los años.

Son los actores discriminados por los estereotipos y prejuicios de la sociedad por la imagen negativa de la vejez, por ello son fundamentales en el presente estudio.

\section{- Familia.}

La familia tiene un rol fundamental en la relación con el adulto mayor, para Valdez (citado en Espinoza, 2018), la familia engloba un sistema de relaciones de parentesco, considerando que no solo involucra los lazos sanguíneos. Es decir, lo primordial en la familia son los vínculos afectivos que serán expresados mediante alianzas, unión, pertenecía entre los integrantes. Son los principales miembros con los que interactúa el adulto mayor, y por lo tanto estimulan su integración en la sociedad.

Para Méndez (citado en Espinoza, 2018), la presencia del adulto mayor en la familia permite la integración de los demás miembros y enriquece los lazos intergeneracionales entre los abuelos y jóvenes, ya que para el adulto mayor lo más importante será su familia, dejando de lado un poco lo social y en casi todos los casos su lado laboral, es por ellos que, desde ese punto de vista para el adulto mayor, el centro de las cosas será su familia. Compartir e interactuar más con 
ellos y en especial con los nietos. El deseo de seguir transmitiendo el conocimiento de padres a hijos. El querer participar en eventos importantes en la familia, ya que la alegría de ellos será la alegría para él o simplemente pasar tiempo con la familia, creando una atmósfera agradable. Es por ello que, la familia debe lograr que el adulto mayor no interrumpa o discontinúe sus relaciones sociales; ya que, son ellas las que ayudan a que el adulto mayor no caiga en un estado de depresión y viva más activo socialmente.

Sin embargo, hoy en día, los cambios en el conocimiento y la tecnología han invertido dicha transmisión, de hijos a padres. Esto ha provocado que el adulto mayor tenga problemas de adaptación a los nuevos cambios de la vida diaria, los familiares tienen el tiempo limitado y van a un ritmo difícil de seguir por el adulto mayor, causando que éste se sienta excluido, o una carga familiar, por lo que son ellos los principales discriminadores de este problema social, por la cercanía y por sus preocupaciones tienden a tratar al adulto mayor como si no fuera apto para tomar sus propias decisiones.

\section{- Amistades.}

Son las personas allegadas al adulto mayor que no son familiares, sino que les une un vínculo de amistad, aquellos con los que pueden estar en contacto con otros semejantes, compartir objetivos comunes e historias, sienten que deben conformar una identidad colectiva, por ende, tienen una necesidad de afiliación. Y esto tiene que ver con el deseo de continuar vinculado al mundo, manteniendo e incluso profundizando las relaciones de afecto y amistad establecidas con las personas que los rodean, así como establecer nuevas amistades que amplíen el espectro social que muchas veces, con el retiro laboral, se ve disminuido.

- Vecinos de la Urb. Santa Isabel. 
Lo conforman todas las personas que viven en la Urbanización Santa Isabel, con los que interactúa el adulto mayor en su vida diaria. Por lo que abarca desde la familia, la misma persona mayor, los bodegueros, panaderos, las diversas tiendas, los que tienen puesto en el mercado, los que viven frente a parques, tanto niños, adolescentes, adultos y mayores, toda la comunidad.

En un ámbito institucional tenemos:

- Casa del Adulto Mayor.

Es la unidad municipal, conformada por un equipo multidisciplinario, busca brindar un espacio adecuado a las personas mayores que han dedicado su vida al desarrollo de la sociedad. Está orientado a implementar programas y servicios que den respuestas oportunas y eficaces a las necesidades de los adultos mayores, por ello brinda talleres, actividades recreativas y diferentes servicios que permiten que las personas compartan y socialicen.

- Centro integral de Atención al Adulto Mayor (CIAM).

Busca mejorar la calidad de vida de las personas adultas mayores (60 Años) que voluntariamente decidan inscribirse y participar en los diversos programas, servicios y talleres. Son espacios creados para la participación e integración social, económica y cultural de la persona adulta mayor, a través de la prestación de servicios, en coordinación o articulación con instituciones públicas o privadas; programas y proyectos que se brindan en su jurisdicción a favor de la promoción y protección de sus derechos. Promoviendo así un envejecimiento activo y saludable para sus beneficiarios.

- Sub Gerencia de Mujer Demuna, Omapel y Adulto Mayor de Carabayllo.

Es la encargada de procesar las actividades que defiendan los derechos del niño y adolescentes, las personas con discapacidad y adulto mayor, en las formas 
señaladas por los dispositivos legales vigentes dentro de la jurisdicción distrital. Encargada de supervisar al CIAM.

- Municipalidad Distrital de Carabayllo.

Institución de gobierno local que tiene la función de administrar los ingresos económicos y desarrollar labores en beneficio y progreso de la comunidad local. Encargada de ejecutar los diversos programas sociales, encargado de crear el CIAM y de informar el funcionamiento de este al Ministerio de la Mujer y Poblaciones Vulnerables.

- Municipalidad de Lima.

Inicia la construcción del Centro Integral del Adulto Mayor para mejorar la calidad de vida de las PAM que viven en los distritos de Lima, por lo que brinda reconocimiento al desarrollo de proyectos, programas o servicios exitosos dirigidos a personas adultas mayores.

- Ministerio de la Mujer y Poblaciones Vulnerables.

Es el principal ministerio que se encarga de ejercer rectoría sobre la promoción y protección de los derechos de la persona adulta mayor. Son ellos los que crean programas y servicios a favor del adulto mayor, en coordinación con los gobiernos regionales, gobiernos locales, entidades públicas, privadas y la sociedad civil, que brindan las facilidades del caso.

- Ministerio de Salud (MINSA).

También implementó servicios especializados para los adultos mayores, y la promoción de un envejecimiento saludable. Creando Clubes de Adulto Mayor, el área La Etapa de Vida Adulto Mayor, Dirección Integral de Salud, entre otras.

- ESSALUD 
Implementó el primer Centro del Adulto Mayor en 1982 en Jesús María, y debido a su éxito, replico a nivel nacional espacios pioneros en el desarrollo de actividades de socialización, buen uso del tiempo libre, de aprendizaje, entre otros servicios.

Entre otros encontramos el Ministerio de Inclusión Económica y Social, el Ministerio del Trabajo y hospitales.

En un ámbito social encontramos:

- Los medios de comunicación.

Que tienen un rol clave en la construcción de la realidad y poder en la opinión pública. De tal forma, tiene una mayor relevancia porque influye en la creación de identidad, alterando la imagen de la realidad con poderosos instrumentos de transmisión ideológica. Así los adultos mayores, tienden a entretenerse viendo televisión, programas en cable o televisión abierta, leer periódicos sensacionalistas, que les permita estar enterado de lo que pasa alrededor. Entre los principales medios que utilizan los adultos mayores tenemos la televisión y los periódicos.

\section{b. Campo.}

Los campos donde se realizará la presente investigación, en base a los objetivos de investigación son:

- La comunidad de la Urb. Santa Isabel.

En este campo se busca tomar registro a través de fotos y video del otro lado del problema, este campo no solo se encontrará a los familiares de los adultos mayores, sino que también se podrá observar las actitudes que tiene la comunidad con el adulto mayor.

- Los parques de la Urbanización Santa Isabel. 
Es uno de los campos donde tienden a socializar los adultos mayores, por lo que se hará registro de estos lugares para poder tener contacto directo con los adultos mayores, es aquí donde se tomará registro e información primordial.

\section{- Los medios de comunicación.}

Tienen un alto poder de influencia en la opinión pública, por lo que se analizará la imagen del adulto mayor en los medios como los diarios y las series de televisión.

\section{c. Método.}

La forma como se accederá al campo y a los actores es la siguiente:

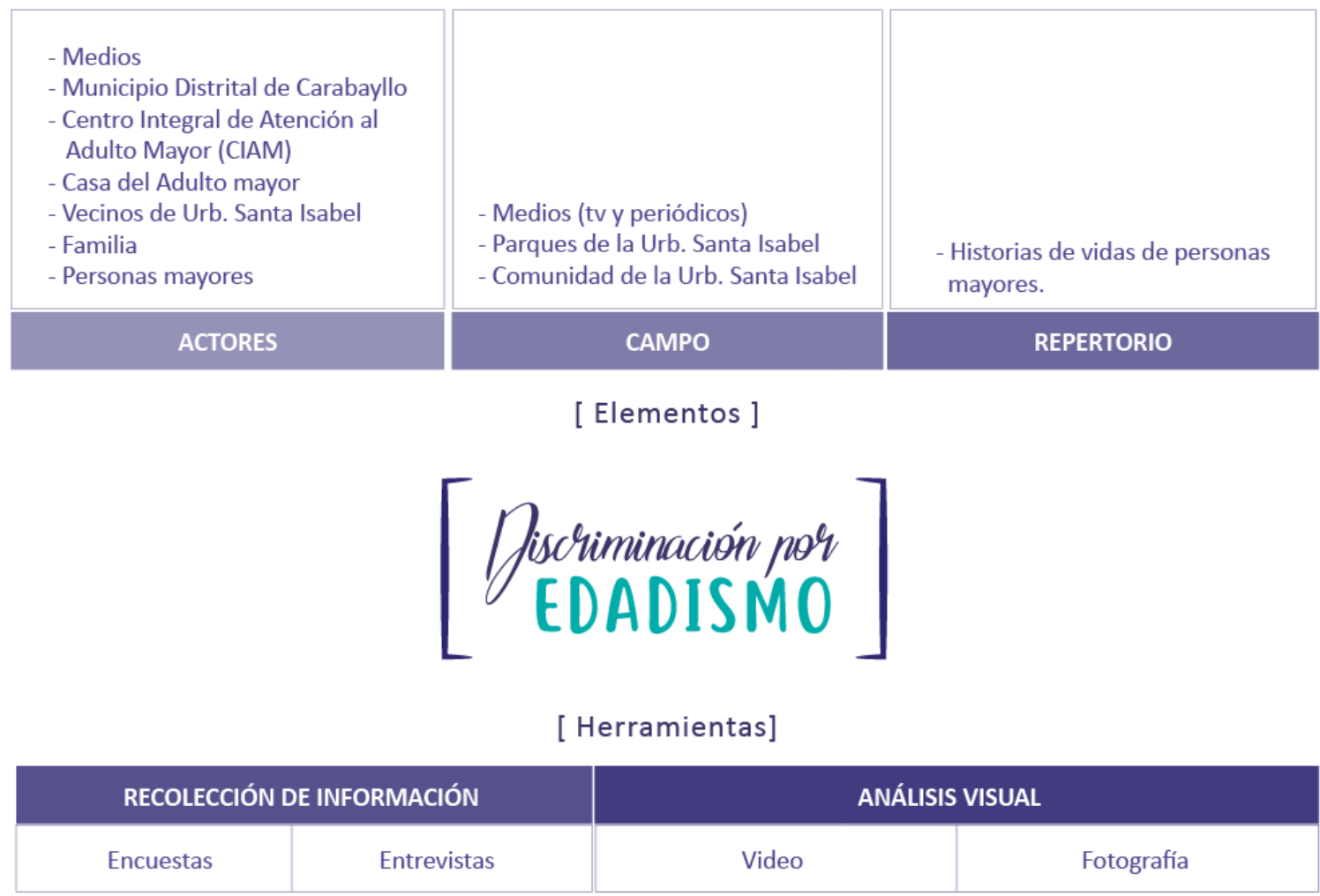

Figura 4. Metodología de la Investigación. Elaboración propia, 2019.

La investigación presenta un enfoque mixto, de tal manera se plantea una serie de herramientas para la recolección de información, así como para el análisis visual que permitirán tener una visión global del problema a investigar. 
En una primera instancia a través de las siguientes herramientas se podrá recolectar información:

- Encuesta.

Se empleo un cuestionario, enfocado en conocer la percepción de la imagen de la vejez en la comunidad, por lo cual, se realizó una encuesta manera digital a través de un formulario de Google, dicha herramienta consta de 14 preguntas cerradas (ver anexo 1).

- Entrevista.

Se realizó una entrevista a cuatro personas mayores (ver anexo 2), dicho instrumento está conformado por 14 preguntas abiertas, que buscan recopilar información relevante sobre las personas mayores y la situación que enfrenta. Así mismo, para tener mejor conocimiento del problema se realizó una entrevista a las personas que viven en la comunidad para poder identificar la imagen que tienen de la vejez y de las personas mayores (ver anexo 3). 


\section{Capítulo I}

\subsection{Marco Teórico}

Con el objetivo de conocer y analizar la discriminación por edadismo que observamos en nuestra realidad, la presente investigación considerará cuatro principales ejes fundamentales de análisis en la investigación: (a) la vejez y la persona adulta mayor (b) la discriminación, el edadismo y el aislamiento social, (c) el diseño gráfico y diseño editorial, y (d) la ilustración. Durante la indagación de información se estimó estos lineamientos como puntos de partida para la literatura de la investigación. Además, se complementó la exploración literaria con los resultados de los instrumentos, recogidos en el campo, para obtener una mejor visión de la problemática.

\section{A. La vejez y la persona adulta mayor.}

\section{a. Concepto de vejez y envejecimiento.}

Como punto de partida, tenemos a Ramos, Meza, Maldonado, Ortega, \& Hernández (2009), quienes nos aclaran el origen de la palabra vejez que surge del latín vetus que a su vez se deriva del griego etos que significa “años”, “añejo”, de ahí que muchas personas lo relacionen con la edad, con el tiempo acumulado, y como un signo del tiempo transcurrido. De tal forma, por su etimología está definida cronológicamente.

Según la Real Academia Española (RAE, 2001) la palabra vejez significa, “cualidad de viejo. Edad senil, senectud. Achaques, manías, actitudes propias de la edad de los viejos. Dicho o narración de algo muy sabido y vulgar”.

Las personas al pensar en la vejez recurren muchas veces a consideraciones de aspectos biológicos, científicos, médicos, psicológicos, etc., sin considerar que el concepto de vejez ha sido abordado a lo largo de la historia, alegando a una tradición del pensamiento, una construcción histórica y sociocultural, que se 
mantuvieron por períodos prolongados, debido a que cada sociedad es la que define y da un significado a las diferentes etapas de la vida de una persona.

Históricamente la vejez fue vista de diferentes maneras, como bien afirma Alba citado en el Instituto Nacional contra la Discriminación, la Xenofobia y el Racismo (INADI, 2017), para las culturas primitivas las personas mayores representaban sabiduría, debido a que eran los encargados de transmitir las experiencias del pasado, atribuyéndoles así, una cualidad sobrenatural o mágica. De igual modo sucedía en las tribus, donde el patriarca era la autoridad, así pues, los consejos de las tribus estaban conformado por personas de mayor edad.

En la antigüedad, tanto en Egipto como en China, la vejez fue considerada como parte significativa de la comunidad. Las personas mayores fueron ligados a la divinidad, la ética, la política, la familia y la sabiduría. Fue en Egipto donde surgió la palabra anciano, como resultado de la expresión egipcia an (manifestación divina) y heh (suma de años). Para las culturas antiguas como los Mayas, los Aztecas y los Incas, las personas de mayor edad eran sujetos de sabiduría, de experiencia ligada al tiempo y la vida humana, por lo que estaban relacionados con aspectos mitológicos y proféticos, literarios, religiosos y filosóficos. (Ramos et al, 2009)

En la antigua Grecia los filósofos, escribas, sacerdotes, etc., escribieron sobre el gran poder y la consideración social que tenían los ancianos por aquellos años, así pues, el consejo de jóvenes griegos recurría al consejo de ancianos antes de tomar una gran decisión. Pero con el tiempo, el anciano va perdiendo dignidad y honorabilidad, como nos comenta García citado en INADI (2017, p. 11), "la vejez constituía una etapa indeseable, tal como quedó reflejado en una serie de relatos entre dioses y en diferentes tragedias, que presentaban una caracterización 
negativa y trágica”. De tal forma, en la mitología griega fue vista como un episodio aberrante y doloroso que vivirían los seres humanos. De ahí, que encontremos una serie de relatos entre luchas de dioses y tragedias donde se representa a la vejez de forma negativa, como lo feo y lo malo (Ramos et al, 2009), desde ese entonces ya se ve a la vejez como pérdida, problema o tragedia.

En la edad media, a raíz de la disminución de la población infantil y juvenil provocada por la peste negra y la viruela, nuevamente se valorizó la figura del anciano en el rol de patriarca, ganando posición social, política y económica. Pero será durante el Renacimiento cuando los ancianos se confrontaron con los cánones de la belleza. Será a partir del siglo XVIII, cuando se comenzó a reconocer cualidades de los ancianos como la experiencia y la capacidad de reflexión, no obstante, el advenimiento de la Revolución Industrial y su política productivista supuso la búsqueda y valoración de aquellos individuos productivos, dándose por entendido que los ancianos presentaban menor capacidad de producción que los jóvenes. (INADI, 2017)

En el siglo XX, el rol de las personas mayores queda relegado al confinamiento en el hogar, asilo, o dependen de algún familiar, teniendo así pocas posibilidades de reconocimiento y oportunidades de desarrollo personal. Y será en esta época, con el surgimiento de la Gerontología, la ciencia que estudia el proceso real de envejecimiento humano, que no solo se "restringe de ningún modo al conocimiento de la vejez como estado vital, sino que se extiende al fenómeno y proceso del envejecimiento, desde aspectos y considerandos pluridisciplinares” (Rodríguez, 1989, p.33), que tomará mayor fuerza e interés el estudio de la vejez. 
Para abordar una definición de la vejez se debe de analizar desde una visión integral, pues es difícil definirlo en un solo concepto cuanto existen diversos factores que convergen. De tal forma, García citado en Ramos et al, enfatiza a la vejez como una etapa de vida de un aspecto biológico, pero también en aspecto filosófico, que no “debe ser interpretada como algo decrépito y negativo, sino como un modo existencial abarcante, ineluctable, inaplazable, como lo es cualquier otra etapa de la vida humana" (2009, p. 51).

Por otro lado, algunos autores gerontólogos o psicólogos del desarrollo prefieren utilizar el término envejecimiento en lugar del término "vejez", y lo definen como "un proceso universal, continuo, irreversible, dinámico, progresivo, declinante y heterogéneo, y, hasta el momento, inevitable, en el que ocurren cambios biopsicosociales resultantes de la interacción de factores genéticos, sociales, culturales, del estilo de vida y la presencia de enfermedades" (Leiton y Ordoñez citado en Gutiérrez, 2013, p. 16), en otras palabras, podemos decir que el envejecimiento es una parte de la vida del ser humano que lo acompaña a lo largo de toda la vida.

Por otro lado, el INADI (2017, pp. 6-7) hace referencia al envejecimiento desde una perspectiva biopsicosocial, analizándolo en tres dimensiones:

El envejecimiento biológico hace referencia a la transformación que sufre el cuerpo a nivel orgánico, por lo que trata de un proceso natural y no de una enfermedad. Se desarrolla desde adentro hacia afuera; el envejecimiento físico es una consecuencia de él, que repercute negativamente en las personas.

El envejecimiento psicológico hace referencia a la transformación de la habilidad motora, sensorial, mental, la personalidad, las motivaciones, 
sensaciones e impulsos. Dentro de él, se encuentra el envejecimiento afectivo y el cognitivo. El primero está relacionado con la capacidad de adaptación a las nuevas o diferentes situaciones de la vida; el segundo tiene que ver con la posibilidad de incorporar o memorizar datos y aprender nuevas capacidades por fuera de las ya aprendidas.

El envejecimiento social está vinculado al ámbito social y a las actividades e interacciones que en él se desarrollan. El medio social demarca el significado de la vejez en la vida de las personas, lo cual influye en la experiencia negativa o positiva de esta etapa.

Es importante mencionar que a pesar de la existencia de los tres enfoques solo se le ha dado mayor peso al biológico, debido a la naturaleza del envejecimiento. Ciertamente, hablar de envejecimiento, es también hablar de edad, la cual es definida por Ginn y Arber citado en Blouin et al. (2018, p. 10) como "una categoría social con un fundamento biológico, pero la biología nos dice poco acerca de su sentido y significaciones sociales", por lo tanto, el envejecimiento no puede ser solo abordado desde un punto de vista cronológico con cambios funcionales, sino también, desde un sentido social abordando conductas y actitudes apropiadas para una determinada edad cronológica, hacia las percepciones subjetivas que tienen las personas mayores de sí mismas, y las que tienen las otras personas (jóvenes y adultos), con quienes interactúan continuamente (Blouin et al., 2018).

Debemos tener claro que ambas palabras, vejez y envejecimiento no significan lo mismo, mientras que el primero es una etapa del ciclo vital del ser humano, el segundo "es una experiencia heterogénea, ya que, existen múltiples factores que la determinan" (Blouin et al., 2018, p. 10) y hace referencia a todo el proceso que 
comienza desde que nacemos y termina con la muerte, y que se da mucho antes de vivir la vejez.

\section{b. Definición de persona adulta mayor.}

El término persona adulta mayor (PAM) hace referencia a la "persona que se encuentra en la etapa posterior a la adultez” (Blouin et al., 2018, p. 11), tomando como referencia un valor numérico específico para determinar el momento en que una persona llega a dicha etapa, una edad base que depende como disponga cada país. De tal manera, en un ámbito internacional:

El artículo 2 de la Convención Interamericana sobre la Protección de los

Derechos Humanos de las Personas Mayores define a la persona mayor como: aquella de 60 años o más, salvo que la ley interna determine una edad base menor o mayor, siempre que esta no sea superior a los 65 años. (Blouin et al., 2018, p. 11)

En el Perú, según el artículo 2 de la Ley de la Persona Adulta Mayor, se entiende "por personas adultas mayores a todas aquellas que tenga 60 o más años", edad base establecida bajo el criterio adoptado por las Naciones Unidas.

Hoy en día, las PAM son tildados en general con otros términos como viejo(a), anciano(a), abuelo(a), vejete, etc., que suelen ser el reflejo de los imaginarios sociales construidos alrededor de las personas mayores. Ver anexo 4 donde se encuentran las expresiones correctas e incorrectas que se relacionan con las personas mayores.

De tal manera, que según la Convención Interamericana sobre Protección de los Derechos de las Personas Mayores en su artículo 2, se refiere a las personas de 60 años o más, según el término de persona mayor e incluyendo el concepto con 
el término de persona adulta mayor (Organización de los Estados Americanos [OEA], n.d.)

Tabla 1

Expresiones anteriores y posteriores a la Convención Interamericana de Protección de los Derechos de las Personas Mayores.

\footnotetext{
Expresiones anteriores

Expresiones posteriores

Viejo(a), viejito(a)

Anciano(a)

Persona mayor

Abuelo(a), abuelito(a)

Adulto mayor (este término cambió al adoptar

el enfoque de género)

Nota: Adaptado de "Nuevas expresiones para referirse a las personas mayores" por MINSAL, 2018, p.2

\section{c. La imagen negativa de la vejez.}

Hablar de una imagen negativa de la vejez, es hablar de edad. Como señala Blouin, Tirado y Mamani (2018, p. 9), "llegar a determinada edad trae como consecuencia una respuesta notoria de la sociedad. Esta respuesta muchas veces impacta de forma negativa en la vida de las PAM, como se puede observar en la falta de oportunidades y el rechazo social que sufre", es por ello, que la edad y el paso del tiempo son vistos erróneamente como un desvalor en la persona, más aún con tantos productos anti-edad que tienden a ser relacionados con lo estético, y ante una sociedad que da primacía a una juventud que tienden a asociarla con productividad, belleza y éxito.

Ante esto, es importante tener claro que la vejez es una etapa de la vida que, como otras contiene tanto aspectos positivos como negativos. Pese a ello, la mayoría de las creencias están relacionadas con la discapacidad funcional, enfermedades, problema cognitivo, entre otros, que generan que las personas adultas mayores sean consideradas como personas enfermas, carentes de
} 
autonomía, asexuadas, con dificultades para aprender e improductivas; creencias que solo incrementa, a crear en la sociedad, una imagen negativa de esta etapa.

Hoy en día, podemos ver diversos actos discriminatorios solo por llegar a la vejez. La revista Sesenta y más (2012, p. 46), en su artículo sobre los mitos y estereotipos asociados de la vejez, describen como los "estereotipos tan afianzados como la dependencia, el aislamiento social o la mala memoria pueden afectar muy negativamente a la propia vivencia del envejecimiento y terminar provocando una profecía autocumplida", es decir, no solo la imagen negativa de la vejez afecta a las actitudes de las demás personas, sino que también influyen en la autopercepción que se tienen las personas mayores.

De acuerdo con el INADI (2017), existen prejuicios, estereotipos y mitos respecto a la vejez productos de la construcción social de las personas que tienden a condicionar a las personas mayores a asumir ciertas conductas esperadas según las creencias discriminatorias. Del mismo modo, afirma que "el conjunto de miradas negativas que tiene la sociedad con respecto a las personas adultas mayores fue definido como viejismo" (p. 12), también denominado "edadismo", que se comprende como la imagen negativa de la vejez acompaña de conductas discriminatorias, juicios negativos y discriminación social por cuestiones de la edad hacia las personas mayores (Sesenta y más, 2012).

\section{d. Estereotipos y prejuicios de la vejez.}

Los estereotipos son concepciones o representaciones generalizadas que se le atribuye a una persona de forma premeditada por el simple hecho de ser parte de un grupo o colectivo social. De tal manera, Lippmann citado en Saez, Meléndez y Aleixandre (1994), considera que es una "percepción incorrecta, producida por razonamientos ilógicos y rígidos” (p. 76), por lo cual estas creencias percibidas 
como similares entre sí pueden implicar una visión tanto negativa como positiva. Tal es el caso de la vejez, que en su visión negativa es percibida por muchos como una etapa de enfermedad, discapacidad, debilidad intelectual y física, entre otros estereotipos que solo limitan a que las personas mayores sean vistas como personas frágiles, improductivas y dependientes. Creencias descalificativas que solo atribuyen a distorsionar la imagen de la vejez en la sociedad, por lo que obstaculiza la integración de las personas mayores, debido, a que los llevan a un aislamiento social que perjudica la calidad de vida, "su salud física y emocional, así como el vínculo intergeneracional y las posibilidades de mutuo enriquecimiento entre los diferentes rangos etarios" (INADI, 2017, p. 29)

Los prejuicios son preconceptos u opiniones que se tiene de alguien de manera anticipada y sin tener el conocimiento necesario. Dulcey (2015, p. 575), lo define como "evaluaciones afectivas, positivas o negativas, generalmente minusvalorantes, basadas en categorizaciones estereotipadas más que en informaciones ciertas y contrastadas con la realidad”. Para el INADI (2017, p. 14) “son juicios de valor que se instalan de manera anticipada con relación a una persona o situación $[\ldots]$ operan de manera inconsciente; $[\ldots]$ ni se comprueba su veracidad", generalmente son negativos dando sustento a prácticas discriminatorias.

Por lo tanto, los estereotipos y prejuicios "dan continuidad no solo a ciertas relaciones de poder en la sociedad, sino a las formas de relacionarnos en la sociedad. Afectan a nuestra participación social, a nuestra forma de interaccionar con otras personas. Nos limita" (Lebrusán, 2019, párr. 4), por lo que afecta a las personas mayores al grado de perder su reconocimiento social, y excluyéndolos de la sociedad, de la comunidad y la vida familiar. 


\section{e. Influencia de los medios de comunicación y la publicidad.}

Vivimos en una sociedad en la que se premia la imagen, que persigue la eterna juventud y que da valor a la persona por sus características físicas y externas, relegando a un segundo plano la experiencia, los conocimientos y la sabiduría que se gana con el paso de los años, y que es propio del envejecimiento. (Sesenta y más, 2012).

En ese sentido, los medios de comunicación cumplen un rol fundamental en la imagen que se les determina a las personas mayores, Piña (citado en Diez, 2016) sostiene como los medios de comunicación refuerzan la imagen negativa del adulto mayor, en cuanto a la construcción social de prejuicios y categorías de la vejez, influyendo a través de propagandas, comerciales, información en la manera en cómo se visibiliza.

De ahí que, según la Fundación Saldarriaga Concha (2013) sostiene que la mayoría de las veces que las PAM son protagonistas de noticias en los medios son (a) porque son víctimas de la delincuencia o accidentes, (b) se descubren avances en el tratamiento de alguna enfermedad, (c) cuando se habla de costos del sistema pensional a futuro, etc., que solo afianza una "imagen antigua, sesgada, con predominio de aspectos negativos que está en el origen de la marginación o exclusión que las personas mayores padecen en muchos ámbitos” (Díaz, 2015, párr. 14).

Tamayo citado en CONCORTV (2017) refiere como:

Los medios dan un espacio reducido al adulto mayor donde se tiende a retratarlo como figura bonachona, o en el otro extremo, como 'el tirano', 'el viejo verde' y demás figuras estereotipadas”, mostrando una imagen de desvalidos que solo pueden dedicarse a ciertas actividades hogareñas. Lo 
mismo pasa en la publicidad, donde se observa una tendencia por reforzar ciertos estereotipos, mostrando en mayor medida a 'abuelitos querendones' y no a adultos mayores trabajando 'como cualquier persona, actuando como seres funcionales'

Tabla 2

Análisis de la imagen que se proyecta de las personas mayores a través de medios de comunicación.

\section{Resumen de resultados}

Medio más usado La televisión de señal abierta (97\%), la cual es vista casi por los PAM todos los días. Los otros medios más consumidos son radio y diarios.

Cómo los $\quad 65 \%$ de las personas mayores encuestadas creen que la muestran televisión muestra una imagen negativa de ellos.

Presencia de Los actores sociales con mayor presencia en la noticia de actores sociales televisión de señal abierta son adultos (94\%), mientras que los adultos mayores solo aparecen en un $2 \%$.

Imagen Tienen una tendencia por enfatizar dolencias y enfermedades proyectada en en los personajes mayores, así como por despojarlos de series/telenovelas rasgos atractivos.

Representación Su aparición suele estar reservada a líderes políticos en noticieros tradicionales; la mayoría aparece relacionada a problemas de salud, violencia o abandono.

Publicidad Existe una invisibilización de este grupo, $\mathrm{Su}$ aparición se da en spots realizados en otros países, presentando a un adulto mayor de rasgos físicos diferentes.

Nota. Adaptado de "Estudio sobre consumo radial y televisivo" por Consejo Consultivo de Radio y Televisión (CONCORTV), 2015; "Análisis comparativo de los principales noticieros de televisión en señal abierta de la ciudad de Lima" por CONCORTV, 2015 y "Los Adultos Mayores en la TV peruana" por CONCORTV, 2017.

Por consiguiente, los medios de comunicación son generadores de opinión, pues los contenidos que transmiten son el reflejo de la sociedad, de ahí la importancia de cambiar los imaginarios en los que esta etapa suele asociarse con deterioro, vulnerabilidad, pobreza y enfermedad, reforzando la concepción que convierte a la persona mayor en una carga social. (Fundación Saldarriaga Concha, 


\section{f. Situación de las PAM en el Perú.}

De acuerdo con el INEI (2019) las PAM conforman el 12,4\% de la población total, lo que evidencia un envejecimiento poblacional como resultado del incremento de la esperanza de vida en todas las edades. De ahí que exista un mayor número de individuos de cada generación que superan los 60 años, sobreviviendo durante más años.

Y pese a que hoy en día es muy común pensar en las PAM como un grupo vulnerable, no es apropiado. Para Araníbar citado en Blouin et al. (2018), los factores de la vulnerabilidad como enfermedad, pobreza y marginación social no son propios de la vejez. Por el contrario, algunos estudios recientes demuestran a las PAM como "una población heterogénea y compleja, activa y capaz de decidir sobre su vida” (Blouin et al., 2018, p. 12). Para mayor detalle se presenta un resumen los principales aportes encontrados en el informe técnico sobre la Situación de la Población Adulta Mayor elaborado por el INEI en el 2019 (ver anexo 5).

\section{g. Marco normativo y programas a favor de las PAM.}

Los Estados tienen la función de eliminar toda legislación discriminatoria, a fin de garantizar el derecho a la igualdad entre el hombre y la mujer, el derecho al trabajo, a la seguridad social, a un nivel de vida adecuado, a la salud física y mental, a la educación y la cultura, y la protección de la familia. Siguiendo esta lógica inclusiva, en la Convención sobre los Derechos de las Personas con Discapacidad se establece que es deber de los Estados luchar contra los estereotipos, los prejuicios y las prácticas nocivas respecto de las personas con discapacidad, incluidos los que se basan en el género o la edad, en todos los 
ámbitos de la vida. De tal manera, a modo de resumen se presenta los hitos más relevantes en la normativa internacional (ver anexo 6).

En un ámbito nacional, dado el contexto actual en el que la población adulta mayor peruana es cada vez más numerosa, la implementación de políticas públicas, programas y servicios específicos para las personas adultas mayores por parte del Estado están regidos bajo tres aspectos: (a) la situación económica, la cual está vinculado a la generación de ingresos, la necesidad de asegurar la satisfacción de sus necesidades básicas en condiciones dignas, por ejemplo, el sistema de pensiones. (b) la situación de salud, referido a la atención de salud, especialmente para prevenir algunas enfermedades, evitando que se vuelvan personas dependientes o discapacitadas. (c) Protección social, enfocada en garantizar los derechos de participación, así como la protección y prevención de violencia, maltrato y abandono. (Mesa de Concertación para la Lucha contra la Pobreza, 2018).

Entre las principales entidades encargadas de atender los tres aspectos mencionados anteriormente tenemos: (a) el Ministerio de Economía y Finanzas (MEF), (b) el Ministerio de Desarrollo e Inclusión Social (MIDIS), (c) el Ministerio de Salud (MINSA), (d) el Ministerio de la Mujer y Poblaciones Vulnerables (MIMP), que es el ente rector en materia de adultos mayores y tiene para ello como órgano de línea a la Dirección de Personas Adultas Mayores (DIPAM). A su vez trabajan a la par los gobiernos regionales y locales. (Mesa de Concertación para la Lucha contra la Pobreza, 2018). Para mayor detalle se presenta un resumen normativo de los últimos años enfocados en la población adulta mayor (ver anexo 7). 
El Perú cuenta con un Plan Nacional de Personas Adultas Mayores, el cual tiene como una de sus medidas: promover una imagen positiva del envejecimiento y la vejez que garantice la inclusión social de las Personas Adultas Mayores con la participación de todos los actores sociales, instituciones públicas y privadas, y medios de comunicación masiva.

Tabla 3

Programas nacionales a favor de las PAM

\begin{tabular}{|c|c|c|c|}
\hline Programa & Entidad & Creación & Objetivo \\
\hline $\begin{array}{l}\text { Programa } \\
\text { Nacional de } \\
\text { Asistencia } \\
\text { Solidaria- } \\
\text { Pensión } 65\end{array}$ & MIDIS & 2011 & $\begin{array}{l}\text { Brindar una subvención a personas adultas } \\
\text { mayores que se encuentran en situación de } \\
\text { pobreza. }\end{array}$ \\
\hline $\begin{array}{l}\text { Vida Digna del } \\
\text { MIMP }\end{array}$ & MIMP & 2012 & $\begin{array}{l}\text { Brindar apoyo a las personas mayores en situación } \\
\text { de calle que no cuentan con apoyo familiar ni de } \\
\text { otros programas sociales. }\end{array}$ \\
\hline $\begin{array}{l}\text { Programa } \\
\text { Presupuestal } \\
\text { 142: Acceso } \\
\text { de PAM a } \\
\text { servicios } \\
\text { especializados }\end{array}$ & $\begin{array}{l}\text { MEF } \\
\text { MIMP }\end{array}$ & 2015 & $\begin{array}{l}\text { Canalizar recursos hacia actividades dirigidas a } \\
\text { fortalecer los servicios de las cuatro principales } \\
\text { modalidades de atención y prevención (los centros } \\
\text { de atención residencial, centros de atención de } \\
\text { noche, centros de atención de día y los centros } \\
\text { integrales del adulto mayor). }\end{array}$ \\
\hline
\end{tabular}

Nota. Adaptado de "Envejecimiento con Dignidad: Una mirada a los derechos de las personas adultas mayores en el Perú" por Mesa de Concertación para la Lucha contra la Pobreza, 2018, pp.76-78

Para mayor detalle se presenta un resumen de los principales servicios que brindan los ministerios y otras instituciones del gobierno nacional a favor de las PAM (ver anexo 8).

\section{h. Autopercepción del Adulto mayor.}

Tomando en cuenta que la sociedad establece modelos y expectativas de roles para cada etapa del ciclo vital, las PAM también tienen roles y estatus que les son impuestos por este imaginario social, sin tomar en cuenta las capacidades y actividades que desarrollan quienes transitan esta etapa. De ahí que, se considera erróneamente que las PAM han perdido la posición profesional, la 
responsabilidad familiar y la participación en diferentes ámbitos sociales, desempeñando un rol más pasivo que en las etapas anteriores.

En virtud de ello, es importante tener en cuenta los modelos de envejecimiento y de vejez que circulan en la sociedad, que influyen tanto en la posibilidad de crear recursos positivos para la vida, como en la configuración de obstáculos para el desarrollo de las personas mayores. Según el INADI (2017, p.22), “los discursos sociales son internalizados a lo largo de la vida, dando origen a estereotipos y prejuicios que son la base de las prácticas discriminatorias”.

Dichas creencias y expectativas que la sociedad tiene sobre el envejecimiento influyen en el comportamiento y la concepción que las personas tienen sobre sí mismas, sobre sus propias capacidades y su autonomía, contribuyendo en la construcción de una imagen desvalorizada y negativa. Como consecuencia, se producen conductas y sentimientos de minusvalía, desamparo, vulnerabilidad y aislamiento que precipitan enfermedades físicas y emocionales directamente ligadas al maltrato recibido.

\section{B. Discriminación, edadismo y el aislamiento social.}

\section{a. Concepto de discriminación.}

El diccionario de la Real Academia Española (2001), define a la palabra discriminación como "acción y efecto de discriminar", entendiéndose la palabra discriminar, en su segunda acepción como "dar trato desigual a una persona o colectividad por motivos raciales, religiosos, políticos, de sexo, de edad, de condición física o mental, etc.”. Así mismo, el Comité de Derechos Humanos citado en la Comisión Nacional contra la Discriminación (CONACOD, 2019, p.13), lo define como: 
Toda distinción, exclusión, restricción o preferencia que se base en determinados motivos como la raza, el color, el sexo, el idioma, la religión, la opinión política o de otra índole, el origen nacional o social, la posición económica, el nacimiento o cualquier otra condición social, y que tenga por objeto o por resultado anular o menoscabar el reconocimiento, goce o ejercicio, en condiciones de igualdad, de los derechos humanos y libertades fundamentales de todas las personas.

Ahora bien, el acto discriminatorio tiene como punto de partida la existencia de un trato diferenciado o desigual hacia una persona o grupo, sin embargo, hay que tener claro, el uso del término discriminación o diferenciación, entendiéndose esta última como "el trato desigual se funde en causas objetivas y razonables" (CONACOD, 2019, p.13), mientras que la discriminación parte de la distinción, exclusión o restricción de los derechos de la persona, es decir, es el trato diferenciado o desigual, sin justificación, que se ejerce sobre una persona o grupo, a manera de exclusión o restricción violando los derechos humanos de las personas.

\section{b. Tipos de discriminación.}

La discriminación es un problema social presente en diversos ámbitos de nuestra sociedad, de tal manera, las prácticas discriminatorias “deshumanizan a las personas por atacar la dignidad misma del ser humano y son un obstáculo para la integración y cohesión social” (Defensoría del Pueblo, 2007).

Estas prácticas son fundadas por algún motivo o ciertas características, de tal manera La Defensoría del Pueblo (2007), distingue: (a) características innatas, que son propios de la persona, independientemente de su voluntad, como la raza, el sexo, el origen, la edad, la identidad étnica o cultural, el idioma, la 
discapacidad, la enfermedad, la apariencia física, condición económica, etc. (b) Por posición asumida voluntariamente como, la religión, opinión, el estado civil, la vestimenta, orientación sexual, etc.

Existen tres principales tipos de discriminación: (a) discriminación por raza, (b)discriminación por sexo y (c)discriminación por edad, nos enfocaremos en esta última. También conocido como edadismo o viejismo, términos que se refieren a “una alteración en los sentimientos, creencias o comportamiento en respuesta a la edad cronológica percibida de un individuo o un grupo de personas" (Levy y Banaji, 2004, p. 1). Es decir, edadismo en las personas, pueden ser consideradas como tal, las ideas, actitudes, creencias y prácticas individuales que son tendenciosas hacia los individuos o grupos a causa de su edad.

\section{c. Concepto de edadismo.}

El término edadismo o viejismo, proviene del término en inglés "ageism", y fue introducido en1968 por el Dr. Robert Butler (IMSERSO, 2009), y hace referencia a los actos, las prácticas y las conductas discriminatorias que vulneran los derechos elementales de las personas mayores y frustran las posibilidades de acceder, en condiciones de igualdad, a los beneficios sociales, culturales, educativos, laborales, recreativos o de salud (INADI, 2017).

Para la revista Sesenta y más (2012), el término hace referencia a los mitos y estereotipos, actitudes y los prejuicios que hay asociados al envejecimiento, por razón de la edad. Es considerado como el "tercer ismo", así pues, Palmore citado en Lozada (2004, p. 3), lo señalo como "la tercera gran forma de discriminación de nuestra sociedad, tras el racismo y sexismo", pese a ello, algunos autores afirman que tiene diferencias frente a las demás discriminaciones, así Martínez, Vivaldo y Mendoza (s.d. p.3), consideran dos razones fundamentales: 
Primero, la clasificación por edades no es estática y en segundo lugar porque nadie está exento de llegar a una edad avanzada, todos experimentaremos la vejez y potencialmente el viejismo. Este fenómeno, afecta al individuo en dos niveles, primero, desde el punto de vista de los estereotipos y prejuicios que uno señala en los otros o, desde el punto inverso, en el que el individuo es estereotipado. Es necesario señalar que ambas formas de viejismo afectan a las personas directamente en el autoconcepto. En este sentido, y debido a que afecta a todas las personas, se ha señalado que el viejismo es el último prejuicio, la última discriminación y el más cruel de los rechazos.

Es decir, cuando se discrimina en general se tiende hacer porque presentan características negativas que los separan de uno, pero en el caso de la discriminación hacia las PAM, se excluye al grupo al que pertenecerán en algún momento, de ahí la gravedad del problema, ya que todos pasarán por la etapa de la vejez.

Por otro lado, Levy y Banaji citado en INADI, sostienen que el edadismo: Tiende a ser naturalizado, puede operar sin ser advertido ni controlado y sin la intención de provocar daño de manera consciente. Todas las personas, en diferentes grados, se encuentran implicadas en la práctica del viejismo implícito. Los procesos y comportamientos mentales que demuestran sensibilidad por la edad se producen automáticamente en los pensamientos cotidianos, sentimientos, juzgamientos y decisiones de la gente común. (2017, p.14)

En ese sentido, podemos decir que la discriminación de las PAM está profundamente arraigada en las personas, donde una mayoría se deja llevar 
inconscientemente por los estereotipos y prejuicios sobre las personas mayores que hay en la sociedad, por ende, son perjudiciales para la salud física y mental del PAM.

\section{d. Tipos de edadismo.}

Para un mejor entendimiento, se realizó una tabla donde se puede distinguir cuatro tipos de edadismo que se observa en la sociedad.

Tabla 4

Tipos de Edadismo

\begin{tabular}{|c|c|c|}
\hline Tipo & Descripción & Ejemplos \\
\hline $\begin{array}{l}\text { Edadismo } \\
\text { en las } \\
\text { personas }\end{array}$ & $\begin{array}{l}\text { Son las ideas, actitudes, } \\
\text { creencias y prácticas individuales } \\
\text { que son tendenciosas hacia los } \\
\text { individuos o grupos a causa de su } \\
\text { edad. }\end{array}$ & $\begin{array}{l}\text { El maltrato físico. } \\
\text { Los estereotipos sobre los } \\
\text { mayores o la vejez. }\end{array}$ \\
\hline $\begin{array}{l}\text { Edadismo } \\
\text { institucional }\end{array}$ & $\begin{array}{l}\text { Lo encontramos en los servicios, } \\
\text { las normas y las prácticas que } \\
\text { discriminan a las personas y/o a } \\
\text { los grupos por su vejez. }\end{array}$ & $\begin{array}{l}\text { La jubilación obligatoria. } \\
\text { La no inclusión de personas } \\
\text { mayores en los ensayos clínicos. } \\
\text { La devaluación de los mayores en } \\
\text { los análisis de coste/beneficio. }\end{array}$ \\
\hline $\begin{array}{l}\text { Edadismo } \\
\text { intencionado }\end{array}$ & $\begin{array}{l}\text { Son las ideas, actitudes y normas } \\
\text { o prácticas llevadas a cabo, a } \\
\text { sabiendas de que son } \\
\text { tendenciosas, contra personas o } \\
\text { grupos por su edad. Incluyendo } \\
\text { las practicas que buscan } \\
\text { aprovecharse de su } \\
\text { vulnerabilidad. }\end{array}$ & $\begin{array}{l}\text { Las campañas publicitarias y los } \\
\text { medios de comunicación que } \\
\text { utilizan estereotipos acerca de los } \\
\text { trabajadores más mayores. } \\
\text { Hacerlo objetivo de las estafas } \\
\text { financieras. } \\
\text { La denegación de formación } \\
\text { profesional a causa de la edad. }\end{array}$ \\
\hline $\begin{array}{l}\text { Edadismo } \\
\text { no } \\
\text { intencionado }\end{array}$ & $\begin{array}{l}\text { También conocido como el } \\
\text { como edadismo involuntario. } \\
\text { Son las ideas, actitudes y normas } \\
\text { o prácticas, llevadas a cabo, sin } \\
\text { que el sujeto sea consciente de } \\
\text { que son tendenciosas hacia las } \\
\text { personas o los grupos basándose } \\
\text { en su edad. }\end{array}$ & $\begin{array}{l}\text { La ausencia de elementos } \\
\text { constructivos en su medio } \\
\text { que tomen en consideración sus } \\
\text { limitaciones (rampas, ascensores, } \\
\text { barandas). } \\
\text { El lenguaje utilizado en los } \\
\text { medios de comunicación. }\end{array}$ \\
\hline
\end{tabular}

Nota. Adaptado de "Edadismo en Estados Unidos" por Instituto de Mayores y Servicios Sociales (IMSERSO), 2009, p. 13

e. Aspectos cognitivos, afectivos y conductuales del edadismo.

El edadismo se expresa bajo tres componentes (INADI, 2017), (a) el cognitivo, (b) el emocional y (c) el conductual. 
El primer componente cognitivo, está estrechamente relacionado con las "creencias que se hacen de las características de los ancianos y el proceso de envejecimiento" (Castellano y De Miguel, 2010, p. 263). Es por lo que, según el INADI (2017), refiere que están relacionados con los estereotipos positivo y negativos que tiene la persona de la vejez y de las PAM.

El segundo componente afectivo, hace referencia a los prejuicios y las preconcepciones que se instalan de manera anticipada con relación a una persona o situación, distorsionando la percepción (INADI, 2017). Por lo tanto, involucra un aspecto afectivo de la conducta, que suele exteriorizarse a través de "sentimientos de hostilidad que infunden un peso emocional negativo y nocivo hacia el grupo en cuestión" (INADI, 2017, p. 30). De tal manera, Del Miguel y Castellano (2012, p. 81), sostienen que:

Los componentes afectivos positivos de las actitudes viejistas se vinculan con la satisfacción vital y un adecuado ajuste emocional, y los componentes afectivos negativos de las actitudes negativas se relacionan con el malestar físico, somático y emocional, con la insatisfacción vital, con la percepción negativa de la salud y con el desajuste emocional.

En ese sentido, podemos decir que los prejuicios están relacionando al aspecto afectivo o emocional, el cual se manifiesta a través de una emoción negativa hacia alguien, mientras que los estereotipos, están relacionados con el aspecto cognitivo, y se manifiesta a través de creencias generalizadas sobre los atributos de un grupo que puede generar un prejuicio. Para Castellano y Del Miguel (2018), la diferencia entre ambos radica en que el estereotipo tiene un carácter descriptivo, en cambio, el prejuicio sería valorativo, emocional y fácilmente detectable. 
Finalmente, los componentes cognitivos y afectivos dan sustento a las prácticas discriminatorias (componente conductual), que se traduce como la negación de los derechos de las personas y colectivos, a partir de falsas creencias y juicios preconcebidos que lleva a ciertas actitudes de repudio y rechazo. Tabla 5

Relación de aspectos cognitivos, afectivos y conductuales

\begin{tabular}{lll}
\hline \multicolumn{1}{c}{ Aspectos cognitivos } & \multicolumn{1}{c}{ Aspectos afectivos } & Aspectos conductuales \\
\hline Se relacionan con los & Se relacionan con los & Se relacionan con la \\
estereotipos. & prejuicios. & discriminación. \\
\hline
\end{tabular}

Nota. Adaptado de "Discriminación por edad, vejez, estereotipos y prejuicios" por Instituto Nacional contra la Discriminación, la Xenofobia y el Racismo (INADI), 2017, p. 30.

\section{f. El aislamiento social como consecuencia de la discriminación.}

Las actitudes discriminatorias por motivos de edad se dan de todas las formas posibles por lo que tiene graves repercusiones tanto para las PAM, como para la sociedad. Por lo cual, se puede observar cómo con la percepción social sobre las personas mayores (basadas en los estereotipos y prejuicios negativos sobre la vejez) está estrechamente relacionado la estigmatización social que afecta en la condición de vida de las personas mayores, al grado de ser rechazados con más facilidad tanto por la sociedad, amistades y, familiares.

De acuerdo con la Federación Iberoamericana de Asociaciones de Personas Adultas Mayores (FIAPAM, 2013), tanto la soledad como el aislamiento "inciden gravemente en la salud y aumenta el riesgo de muerte entre las personas de más de 50 años", por ende, el edadismo tiene efectos nocivos sobre la salud de las personas mayores, pues estos pueden acabar desempeñando el rol que la sociedad 
le impone, al grado de pensar que su vida tiene menos valor y, como consecuencia de ello, son más proclives a la depresión y el aislamiento social.

Géne et al (2016, p. 605), define al aislamiento social como "la situación objetiva de contar con mínimos contactos con otras personas”, Molina y Muñoz (2015, p. 12), afirman que se centra en la "sensación de soledad impuesta por los demás”. Mientras que Jiménez (citado en Molina y Muñoz), lo considera como el “proceso de desligamiento [...] en el que en virtud del cual el individuo añoso abandona actividades o rompe lazos sociales de convivencia de manera voluntaria o forzado por el rechazo que percibe", (2015, p. 27).

Así mismo, se debe tener claro el concepto de soledad y la diferencia con aislamiento social, ya que estos dos términos tienden a ser confundidos como uno mismo. De tal forma, según Géne et al (2016, p. 605) la soledad "es la sensación subjetiva de tener menor afecto y cercanía de lo deseado en el ámbito íntimo (soledad emocional), de experimentar poca proximidad a familiares y amigos (soledad relacional) o de sentirse socialmente poco valorado (soledad colectiva)", mientras que para Molina y Muñoz, "se define como el estado aversivo experimentado cuando existe una discrepancia entre las relaciones interpersonales deseadas y las percibidas en cada momento" y el aislamiento lo define como "la ausencia de relaciones sociales satisfactorias y de un bajo nivel de participación en la vida comunitaria" (2015, p. 26). Es decir, la soledad es el hecho de sentirse solo, mientras que el aislamiento social hace referencia a la condición real de estar solo la mayor parte del tiempo, que puede ocurrir por tener una red social de apoyo muy pequeña o pocas oportunidades para interactuar socialmente.

\section{Diseño gráfico y diseño editorial.}


Si se mira alrededor, todo lo que rodea el entorno es diseño. Día a día el hombre interactua con una infinidad de marcas, mensajes publicitarios, señales de tráfico, símbolos, letreros, etiquetas, videos, imágenes, etc., que juegan un rol vital en el mundo contemporáneo. Realmente se esta rodeado del diseño desde el principio de los tiempos. Y es que a través de la historia, el hombre siempre a encontrado la forma de comunicarse, de transmitir y recibir ideas, sentimientos y emociones, encontrando la forma de expresión adecuada a su escencia.

Vivimos en una época en que todo entra por los ojos, donde cada segundo interactuamos y consumimos imagen, desde que nos levantamos hasta que nos acostamos, todo lo que nos rodea nos llega a través de la imagen con algún mensaje que nuestro cerebro recibe diariamente.

\section{a. Definición de diseño y diseño gráfico.}

La palabra diseño, proviene del latín "designare”, que significa designar, destinar algo para un fin determinado. Por lo que, "el diseño es un proceso cuya finalidad es la resolución de los problemas planteados en función de alguna necesidad" (López, 2014, p. 26). Existe una gran variedad de definiciones sobre diseño gráfico, ya que se aplica a muchas áreas. De tal manera, Santa (s.f., p. 29) manifiesta como:

El término "diseño", según el contexto posee distintos significados: puede ser sinónimo de proyecto, idea, plan o propósito — proviene del inglés design $[\ldots]$. Puede ser sinónimo de plano, esquema, boceto, dibujo, o croquis — cuando se trata de una acepción latina del término disegnare-. A partir de la combinación de estas dos acepciones podemos alcanzar una aproximación del sentido actual de la palabra “diseño". Este se refiere a una disciplina técnico-creativa consistente en la operación abstracta de 
proyectar, prefigurar y concebir íntegramente objetos o imágenes que componen el entorno físico y simbólico de las actividades sociales.

Existen diversas áreas donde el diseño actúa, como el espacio, los objetos y los mensajes. En el primer ámbito, espacio, se puede encontrar el urbanismo, arquitectura, diseño de interiores e ingeniería. En el segundo ámbito, los objetos, se encuentra las ingenierías, el diseño industrial, el diseño textil entre otros y en el tercer ámbito, de los mensajes, se encuentra la comunicación visual o diseño gráfico.

A lo largo de su desarrollo han surgido diversos conceptos sobre el diseño gráfico, de tal manera para una mejor comprensión se recopila a continuación conceptos de diversos autores.

Según Moholy (citado en García, 2019) el diseño gráfico:

"Posee innumerables concertaciones. Es la organización, en un equilibrio armonioso de materiales, de procedimientos y de todos los elementos que tienden a una determinada función. El diseño no es una fachada ni una apariencia exterior. Más bien debe penetrar y comprender la esencia de los productos y de las empresas. Su tarea es compleja y minuciosa. [...] Integra los requerimientos tecnológicos, sociales y económicos como las necesidades biológicas o los efectos psicológicos de los materiales, la forma, el color, el volumen o el espacio. Su formación tiene que contemplar tanto la utilización de los materiales y de las técnicas como el conocimiento de las funciones y los sistemas orgánicos.”

Para López (2014) “el diseño gráfico es el responsable de comunicar visualmente todo tipo de información" (p. 14). Mientras que para el American Insttitute of Graphic Arts (citado en López, 2014), “es un proceso creativo que 
combina el arte y la tecnología para comunicar ideas. (p. 21). Por lo tanto, el diseño gráfico es la acción de concebir comunicaciones visuales orientadas a transmitir ideas o mensajes específicos.

Así mismo, Sánchez y López (2012, p. 12) definen al diseño gráfico como: Una disciplina intelectual, social, cultural e interdisciplinar orientada a la comunicación, a la solución de problemas indeterminados, que apela a la funcionalidad y a las motivaciones de compra, de asistir a un concierto, de pertecener a grupos, y más. El proceso del diseño es complejo, creativo, depende de la forma de decisiones, de analizar y aplicar estrategias destinadas a desarrollar una solución efectiva.

Es decir, es una disciplina interdisciplinar que busca resolver diversos problemas de comunicación, cuya complejidad se halla en hacerlo de la manera correcta, ya que se debe tener en cuenta los aspectos psicológicos, sociales y culturales de la percepción humana. Para ello, según Frascara (2000) el diseño gráfico "es la acción de concebir, programar, proyectar y realizar comunicaciones visuales, producidas en general por medios industriales y destinadas a transmitir mensajes específicos a grupos determinados” (p. 19). Por lo tanto, el diseño gráfico transmite un mensaje en específico utilizando diversos elementos gráficos que permiten su fácil entendimiento para determinados públicos objetivos. Por lo tanto, el diseño gráfico es funcional, y el diseñador es un mediador encargado de traducir el mensaje del emisor al lenguaje visual, al "codificar, dar forma y estructurar los mensajes, traduciéndolos al idioma o lenguaje visual que pueda ser captado y comprendido por el receptor” (López, 2014, p. 20).

\section{b. Fundamentos del diseño.}


Para abordar el lenguaje visual se debe conocer en primer lugar los principios básicos del diseño. Para Wong (1991, pp. 11-12) los elementos están estrechamente relacionados y no pueden ser separados, por lo que distingue cuatro grupos de elementos:

\section{- $\quad$ Elementos conceptuales.}

Son los elementos que no son visibles pero que solo parecen estar presentes. En este grupo se puede encontrar al punto (que indica posición, más no tiene largo ni ancho, ni ocupa una zona del espacio), la línea (que es el recorrido del punto, y está limitada por este, por lo que tiene largo más no ancho, tiene posición y dirección), el plano (es el recorrido de la línea en movimiento, por lo que está limitado por estas, tiene largo y ancho más no grosor) y el volumen (que es el recorrido del plano en movimiento, tiene posición en el espacio).

- $\quad$ Elementos visuales.

Son los elementos que realmente vemos en el diseño, los elementos que permiten ser visibles a los elementos conceptuales, a través de la forma (que permite la identificación de todo aquello que es visto a través de la percepción), la medida (que es el tamaño de los objetos vistos), el color (que distingue de sus cercanías por medio del color) y la textura (que permite distinguir de acuerdo a la superficie de una forma, atrayendo tanto por el sentido del tacto como la vista).

\section{- $\quad$ Elementos de relación.}

Se basan en la ubicación e interrelación de las formas en un diseño. Por lo que pueden ser percibidos a través de la dirección (que depende de la relación con otras formas cercanas, el marco que lo contiene y el 
observador), la posición (depende de la relación respecto al cuadro o estructura del diseño), el espacio (que es lugar que ocupan o no las formas según sus tamaño en el espacio), y gravedad (es la sensación de pesantez o liviandad, estabilidad o inestabilidad que se le atribuye a las formas).

\section{- Elementos prácticos.}

Son los que subyacen el contenido y el alcance de un diseño. En este grupo se encuentra la representación, que se da cuando la forma es representativa, la cual puede llegar a un grado de realista o semi abstracta. El significado, que se presenta cuando el diseño transporta un mensaje. La función, la cual se hace presente cuando el diseño cumple un determinado propósito.

\section{c. El diseño editorial.}

Según Martínez (citado en Puetate, 2014, p. 27), “el diseño editorial apareció al mismo tiempo que la escritura y se desarrolló paralelamente con la necesidad de los hombres por grabar en cualquier superficie sus ideas y pensamientos". Un gran ejemplo de esto son los papiros egipcios, donde sus escribas ya hacían diseño editorial en sus manuscritos. Por lo tanto, se puede decir que el diseño editorial nace como una necesidad de comunicar por medio de una expresión cultural.

Para Venezky (citado en Eguaras, 2018, párr. 16) “es el marco a través del que una historia dada se lee e interpreta. Consiste tanto en la arquitectura global de la publicación (...) como en el tratamiento específico de la historia $(. .$.$) ", del mismo$ modo, Haslam (citado en Eguaras, 2018, párr. 20) manifiesta como "es una mezcla de decisiones racionales y conscientes que se pueden analizar y de otras 
subconscientes menos fáciles de definir, ya que surgen de la experiencia y la creatividad de cada diseñador".

De tal manera, el diseño editorial es una rama del diseño gráfico, que se “especializa en maquetación y composición para la realización de diferentes publicaciones" (Zanón, 2007, p. 9), desde libros, revistas, periódicos, etc., por lo que básicamente tiene como función principal organizar en los espacios las imágenes, textos, ilustraciones, etc, guardando un equilibrio estético que resulte funcional para el receptor. El diseño editorial busca atraer la mirada del público, por lo que se encarga de hacer atractiva a simple vista cualquier tipo de publicación, para transmitir todo su contenido sin cargar ni saturar.

El diseño editorial abarca desde la gráfica interior y exterior de los textos, basándose en un eje estético ligado al concepto que define a cada publicación, por lo que "cubre todos los aspectos necesarios para transmitir el mensaje de la mejor forma y, además, conseguir que todo el conjunto, a nivel estético y de contenidos, transmita parte de lo que constituye a la marca que hay detrás” (Neoattack, 2019, párr. 3).

Por lo que "el principal objetivo del diseñador profesional es crear un diseño que resulte atractivo y funcional para el lector y conseguir una armonía perfecta entre forma y contenido" (Estudio Mike, 2019).

\section{d. Elementos que componen una pieza editorial.}

Para que una pieza editorial sea eficiente y pueda llevar el mensaje de manera correcta, se debe tener en cuenta ciertos elementos importantes en la composición de este.

Como manifiesta Puetate (2014, pp. 32), estos elementos son:

- La composición. 
Es la forma acertada de disponer los elementos del libro de manera coordinada y estética, mismos que le darán singularidad a dicho libro. Dentro de la composición, están los principios de composición y a su vez los elementos de la composición.

Entre los principios menciona: (a) Unidad y variedad, que depende en cuanto a la disposición de elementos y espacios. (b)Simetría, que se da cuando ambas partes se encuentran en igual correspondencia. (c) Asimetría, la cual sucede cuando falta un eje central, pero que mantiene una estabilidad visual. (d) Proporción, que permite distribuir adecuadamente los tamaños de formas y elementos del diseño en cuanto a dimensiones y forma. (e) Equilibrio. Es evitar la sobrecarga visual y acertar en la variación de contrapeso de los elementos. (f) Ritmo, el cual se distingue por el movimiento visual aparente, la acción y la repetición de preceptos. (g) Contraste, que se da con el uso de elementos contrapuestos, que dinamizan la composición.

Dentro de los elementos de la composición, menciona: (a) el formato, que refiere al tamaño de la pieza, que según su dimensión puede ser apaisado, cuadrado, prolongado. Y (b) la caja gráfica (que es el área de impresión en el cual se va a disponer el texto, imágenes e ilustraciones. Por lo tanto, posee un margen interior y exterior.

De tal manera según Puetate (2014), los elementos no son normas inamovibles pues depende de la pieza editorial que se desarrolla. Por lo cual, puede emplearse muchos de estos elementos que permita una lectura satisfactoria y legible. Por ejemplo, en el caso de un cuento infantil, los títulos y textos son imprescindibles, sin embargo, no necesitan tener pie de 
foto ya que como son productos para niños y las ilustraciones expresan la propia narración.

- La diagramación.

Según Cumpa (2002, p.5), “diagramar es distribuir, organizar los elementos del mensaje bimedia (texto e imagen) en el espacio bidimensional (el papel) mediante criterios de jerarquización (importancia) buscando funcionalidad del mensaje (fácil lectura) bajo una apariencia estética agradable (aplicación adecuada de tipografía y colores)”. Por lo tanto, podemos decir que es la manera de disponer los elementos en el espacio.

Entre los elementos de la diagramación se puede observar: (a) las imágenes, donde abarcan las ilustraciones manuales o digitales, fotografías, infografías, diagramas o cuadros estadísticos, viñetas y logotipos. (b) Los textos que incluye desde los títulos, antetítulos, subtítulos, gorro, capitular, leyendas, cuerpos del texto, autores, fotografía, numeración, etc. (c) Los recursos gráficos, que abarcan las líneas, tramas, signos, señaléticas, marcadores de leyenda, fondos texturizados, recuadros de texto, etc.

\section{- Retícula.}

Son los trazos verticales y horizontales en el espacio de diagramación, que permite crear módulos para poder combinar y distribuir los elementos de la composición (Puetate, 2014).

- La página.

Es la cara de la hoja con el contenido en ella, para Zanón (2007, p. 31), “toda página bien diseñada posee equilibrio, es decir, tensión y relajación. 
Independientemente de la disposición de los elementos, el ojo busca el eje de sentido en cualquier página".

- Tipografía y composición tipográfica.

Como manifiesta Turnbull y Baird (citado en Puetate, 2014) "lo que interesa primordialmente al lector respecto a las palabras es el mensaje que transmiten", por lo que es primordial la elección correcta del tipo de letra que permita llamar la atención y a la vez sea fácil de comprender por el lector. De tal forma, la tipografía elegida debe ser elegida según varios criterios, como el mensaje a transmitir, el estilo y según el público objetivo.

- El color.

Para López (2014, p.88), el color puede trasmitir "sensaciones, sentimientos, estados de ánimo, puede transmitir mensajes, expresar valores, situaciones y, sin embargo, el color no existe más allá de nuestra percepción visual”. De tal manera, el color desempeña un papel muy importante dentro del diseño de una pieza gráfica, debido a que influye en el mensaje, cuyo significado puede variar notablemente dependiendo los colores utilizados en la representación gráfica.

\section{e. Productos editoriales.}

Hoy en día existen una gran variedad de productos editoriales, entre las principales piezas editoriales tenemos: las revistas, los periódicos y los libros. Sin embargo, existen otras publicaciones propias del diseño editorial: catálogos, informes, manuales, guías, cuentos, fábulas, mitos, poemarios, dípticos, trípticos, folletos, etc., y es que como manifiesta Eguaras (2012) “cualquier publicación que pretenda comunicar una idea o contar una historia mediante la organización y presentación de palabras y elementos gráficos necesitará del diseño editorial”. 


\section{f. El cuento.}

Etimológicamente, el término deriva del latín computus, que significa cálculo, cuenta. En primer lugar, está relacionado con aquellas actividades asociadas a lo numérico; y, en segundo lugar, se le asocia a la voz popular, al quehacer humano de narrar o contar historias (Gonzáles, 2016).

De acuerdo con Aguilar y Silva (citado en Martínez, 2012, p. 1) es “una narración breve, de trama sencilla y lineal, caracterizado por una fuerte concentración de la acción, del tiempo y del espacio", donde la historia parte de sucesos imaginarios o acontecimientos reales y cuya acción es llevada a cabo por personajes en determinados escenarios.

Para el Instituto de Andaluz de la Mujer (2006), es un recurso didáctico muy utilizado hoy en día en las aulas educativas, ya que pueden ser transmitidas de manera oral o impresa. Y es a través de los cuentos por donde se inculca a las nuevas generaciones valores, elementos motivadores o contenidos conceptuales. En resumen, por medio del cuento:

- Socializamos, inculcamos ideas, creencias y valores sociales.

- Legitimamos instituciones o instancias sociales, funciones y roles.

- Transmitimos modelos de actuación.

- Ofrecemos modelos de identificación desde el punto de vista emocional.

- Enseñamos cómo solucionar conflictos.

- Mostramos un mundo mágico, que el niño y la niña viven, y en el que pueden descargar la agresividad, la ansiedad y los miedos reales.

- Ofrecemos una fuente de imaginación y creación. A partir de ellos, alumnas y alumnos crearán sus propias historias e imaginarán su mundo 
ideal, sus sueños y sus pesadillas. (Instituto de Andaluz de la Mujer, 2006, p. 5)

Además, el cuento tiene mayor alcance ya que "cabe todo lo real y lo maravilloso, la enseñanza y la diversión, [...] el mundo cotidiano y el ensueño misterioso, el mundo infantil y el del adulto, el amor y el odio, [...] la venganza y la generosidad" (Martínez, 2012, p.1).

- $\quad$ Características del cuento.

Según López (2018), los aspectos básicos que debe presentar un cuento son: (a) forma, que se refiere a utilizar un lenguaje determinado y estructurado, con palabras, frases y párrafos precisos. Y (b) contenido, se refiere a los personajes, a sus acciones y a la historia.

Así mismo, para Tabuenca (2019) las principales características que presenta el cuento son: (a) sintetiza lo más posible la narración por lo que cuenta con un texto breve (lo que lo diferencia de otros textos literarios), (b) la historia se desarrolla en una estructura sencilla, (c) narra una sola línea argumental, por lo que todos los acontecimientos se encadenan en una sola sucesión de hechos. (d) Cuenta con pocos personajes, para no abrumar al lector y la comprensión sea sencilla. Por lo que, la historia cuenta mayormente con un protagonista, a quien le sucede los hechos principales. Asimismo, (e) tiene una unidad de efecto, debido a que se lee de principio a fin en un mismo momento, por lo que busca despertar una reacción emocional impactante en el lector. (f) Cuenta con una tensión narrativa, que anima al lector a seguir leyendo, debido a que tiene textos breves, que le permiten mantener el ritmo de la historia. (g) Predomina la fantasía del autor, pese a que puede partir de una historia real, se visten bajo la capa de 
la ficción. (h) Se escribe en prosa, pues sigue una estructura básica de organización textual.

- Clasificación de cuentos.

"Hay cuentos y cuentistas para todos los gustos [...], tienen diversas formas, tamaños y contenidos" (López, 2018, párr. 20). Desde el siglo XVIII, hay varios intentos de clasificarlos, pero son pocos los que llegan ajustarse en un tipo. Por ello López lo agrupa según autor, destinatario, tema o personajes.

Tabla 6.

Clasificación de cuentos

\begin{tabular}{llll}
\hline Según autor & $\begin{array}{l}\text { Según su } \\
\text { destinatario }\end{array}$ & Según el tema & \multicolumn{1}{c}{ Según el personaje } \\
\hline Cuentos & Cuentos & Cuentos & Cuentos de hadas, \\
populares & infantiles & fantásticos & princesas... \\
Cuentos & Cuentos para & Cuentos de & Cuentos de espías, \\
literarios & adultos & terror & policías... \\
& & Cuentos de & Cuentos de animales \\
& amor & Cuentos de personajes \\
& Cuentos de & históricos \\
& suspenso & Cuentos de fantasmas y \\
& & monstruos \\
\hline
\end{tabular}

Nota. Adaptado de "El cuento y su valor” por López, 2018, párr. 22

Según la primera clasificación encontramos a los cuentos populares, que son narraciones tradicionales breves donde mayormente se desconoce al autor, y tienden a ser transmitidas de vía oral. Para López (2018, párr. 26) se caracteriza por narrar:

Hechos imaginarios que se presenta en múltiples versiones, todas las cuales coinciden en la estructura, pero difieren en los detalles [...]. Hay tres subtipos: los cuentos de hadas, los cuentos de animales y los cuentos de costumbres. El mito y la leyenda son también narraciones 
tradicionales, pero suelen considerarse géneros autónomos. Un factor clave para diferenciarlos del cuento popular es que no se presentan como ficciones.

Así mismo, encontramos los cuentos literarios, que se caracteriza por ser una obra de un autor conocido y transmitidas por vía escrita. "El texto, fijado por escrito, se presenta generalmente en una sola versión, sin el juego de variantes características del cuento popular de tradición fundamentalmente oral” (López, 2018, párr. 27).

- $\quad$ Estructura del cuento.

Según López (2018), el cuento presenta tres partes:

La introducción, es la parte inicial del cuento, que presenta la historia, los personajes y sus propósitos. Debe situar el lugar donde se desarrolla la acción, así mismo, es aquí donde se "sienta las bases para que el nudo tenga sentido".

El desarrollo, también conocido como nudo, es la parte que presenta el conflicto o problema de la historia, por ende, presenta los hechos más importantes.

El desenlace, es el final de la historia, donde sucede el clímax, y donde se da solución al problema.

- $\quad$ Elementos del cuento.

Para Tückler (1998, p. 161) los principales elementos del cuento son: El ambiente, es el lugar o espacio físico donde se desarrolla la acción. Sirve para crear una referencia de espacio y tiempo que modelan la narración.

La trama, es el conflicto que mueve a la acción. 
La intensidad, se refiere al desarrollo de la idea principal, eliminando las superfluas.

La tensión, son los ajustes de elementos formales y expresivos del tema para captar la atención del lector o del oyente.

La atmósfera, es la sensación emotiva de la narración (alegría, misterio, tranquilidad, entre otras sensaciones).

El tono, es la inflexión intencionada del sonido, la letra escrita, el modo particular de expresarse; es la actitud con que se maneja una circunstancia, la cual puede ser humorística, alegre, irónica, sarcástica.

Los personajes, son los protagonistas, cuya conducta debe estar acorde con el papel que presentan dentro de la obra.

La estructura, es el orden interno de toda unidad narrativa.

\section{La ilustración.}

Como hace referencia Fernández (2012, p. 14), "la imagen ha ido ganando espacio al texto", pues la información gráfica es más memorable que la información escrita, por lo que permite sintetizar conceptos y minimiza los procesos de aprendizaje, en otras palabras la imagen es más sencilla de entender.

Un gran ejemplo es la ilustración que va más alla de trasos y dibujos, jugando un papel en el diseño como herramienta de comunicación.

\section{a. Concepto de ilustración.}

Como hace referencia Ortega (2007), algunos profesionales ilustradores consideran que la ilustración es "una rama de la pintura y del dibujo que produce obras de arte destinadas al gran público” (p. 40). Dadley (citado en Espinoza, 
2015, p. 9), define la ilustración como la "acción de dibujar o plasmar algo. Asimismo, asocia a la ilustración como una función cognitiva de la imagen”.

Por otro lado, Siliezar (citado en Espinoza, 2015, p. 9) lo define como “el componente gráfico que complementa o realza un texto. Agrega que las ilustraciones pueden ser mapas, planos, diagramas o elementos decorativos los cuales generalmente representan escenas, personajes u objetos que tienen relación directa, indirecta o simbólica".

Desde una perspectiva gráfica, Sánchez (s.f., p. 17) la define como:

La traducción de información del lenguaje escrito u oral a dibujos, pinturas o fotografías. Esta traducción se da con el uso de herramientas prestadas de las artes pictóricas. En este caso el mismo uso de la palabra ilustrar abarca lo más importante de la comunicación, la necesidad de hacer llegar un mensaje a unas personas que pueden tener diferentes lenguas, costumbre, hábitos sociales y maneras de ver las cosas.

Otros investigadores consideran que la ilustración es un lenguaje que comunica un mensaje. Fernández (2012), define a la “ilustración es una disciplina que forma parte de todo un proceso global de comunicación" (p. 16), por lo que guarda un lenguaje condicionado en el mensaje, “cada vez más, la ilustración ya no es un fin sino un engranaje, una vía de transmisión” (Fernández, 2012, p. 25).

Así mismo, Sánchez (s.f., p. 17) considera que la ilustración es: Aquella imagen iconográfica estática (impresa) o en movimiento (pantalla), cuyas cualidades oscilan entre lo comunicativo y lo expresivo, que tiene una dimensión definida en píxeles o centímetros, y que puede ser llamada también dibujo o lámina. Hay un valor estético imprescindible en las 
ilustraciones, que las distingue de aquellas imágenes que simplemente están determinadas para transportar información.

Por lo tanto, Dalley (citado en Espinoza, 2015, 9), lo define como “el objetivo de todo arte visual es la producción de imágenes. Cuando estas imágenes se emplean para comunicar una información concreta, el arte suele llamarse ilustración”. Es decir, "ilustrar es comunicar y la comunicación no solo es un dibujo sin más" (Fernández, 2012, p. 16), por lo que la idea de que ilustrar es igual a dibujar es errónea. "Un dibujante es libre de trazar aquello que desee. Un ilustrador está sometido a una visión comercial en cuanto a los resultados. Ilustrar sirve para vender comunicando" (Fernández, 2012, p. 19).

\section{b. Características de la ilustración.}

Para Ortega (2007, pp. 40-41), las principales características que guarda una ilustración son:

- La capacidad de significación inmediata y evidente.

- Poder de persuasión y eficacia para la comprensión e interpretación de un relato.

- Es una forma de arte visual representativo o figurativo, donde predomina la síntesis simbólica (que es superior a la figurativa).

- Capacidad de simbolizar un elemento sin necesidad de representarlo tal cual es, por lo que juega mucho con la memoria.

- Es un arte instructivo que enriquece el conocimiento visual y la percepción de las cosas.

- Interpreta y/o complementa un texto, es decir visualmente ayuda aclarar lo que no se puede expresar con palabras. 
- Pueden reconstruir el pasado, reflejar el presente, imaginar el futuro o mostrar situaciones imposibles en un mundo real o irreal.

- Las ilustraciones pueden ayudar, persuadir y avisar de un peligro; pueden desperezar consciencias, pueden recrear la belleza o enfatizar la fealdad de las cosas.

- Pueden divertir, deleitar y conmover a la gente.

Así mismo, para Fernández (2012) la principal característica de la ilustración es su capacidad de contar una historia con un objetivo, pues es una poderosa herramienta de comunicación, a lo que agrega como "los ilustradores comunicamos, a través de nuestros dibujos, aquello que se nos pide narrar" (p. 25).

\section{c. La ilustración y su potencial comunicacional.}

Se debe tener claro que existen dos grupos que tienden a definir a la ilustración, el primero considera que la ilustración es meramente una rama de la pintura y del dibujo destinada a un público, mientras que, para el segundo grupo, es un lenguaje, quizá más narrativo, condicionado al mensaje. Por lo cual, la ilustración deja de ser un fin, para volverse una vía de transmisión (Fernández, 2012). Es decir, "la ilustración es ahora herramienta de comunicación" (Fernández, 2012, p. 25), donde la ilustración cuenta una historia que se necesita comunicar, respondiendo a una necesidad concreta.

Por lo tanto, según Fernández (2012), el ilustrador es parte del proceso de comunicación de una idea, producto o concepto que se pretende hacer llegar a un consumidor final, por lo que guarda intención social determinada por un cliente. Es un narrador de encargo, pues se encarga que el mensaje que se pretende comunicar llegue fácilmente al consumidor de manera fácil y lo más directamente 
posible. Así mismo, el autor agrega como las ilustraciones aportan un "valor añadido a un concepto que proviene de un tercero desde una imagen dibujada específicamente para ello" (Fernández, 2012, p. 20).

\section{d. Tipos de ilustración.}

A continuación, se describe algunos tipos de ilustración que permitirá comprender mejor el tema.

\section{- $\quad$ Ilustraciones conceptuales.}

Según Sanmiguel y Canal (2013), en aquella que no se ciñe en datos proporcionados por textos, argumentos o información, sino que busca desarrollar una idea personal nacida de las consideraciones que hace el ilustrador acerca del tema que se propone ilustrar.

En este grupo se considera: (a) las ilustraciones creativas, (b) los recursos técnicos y (c) las ilustraciones decorativas, que busca embellecer las páginas de un texto, y enriquecer el diseño gráfico de la publicación. En este grupo también se rigen las ilustraciones de portadas, por lo que sus principales características son:

Es creativa y su éxito radica en el estilo original del ilustrador.

Representa ideas generales y no hechos específicos.

El ilustrador debe trabajar bajo una línea editorial de la publicación.

\section{- Ilustraciones narrativas.}

Sanmiguel y Ubach (2014) las definen como aquellas que consiguen una expresión gráfica de un argumento. En este grupo se consideran (a) la ilustración de obras literarias, que acompañan los relatos y las narraciones clásicas que siguen un suceso según un guion literario, (b)las ilustraciones de humor gráfico, que transmite ingenio y humor a través del grafismo, por 
lo general un caricaturesco. Por lo general se observa en publicaciones periodísticas. (b) La ilustración infantil, que abarca un inmenso campo y donde es muy importante tener presente la edad del público. Para este tipo de ilustraciones se debe de dar una interpretación clara y legible del tema. (c) El Comic, muchos lo consideran un mundo aparte, sin embargo, también debe seguir un guion, el cual debe ser muy bien plasmado con personajes bien caracterizados.

\section{- $\quad$ Ilustración publicitaria.}

Para Sanmiguel y Ubach (2014) están enfocadas en complementar la personalidad de un producto o marca, o anunciar un acontecimiento. Guardan distintos formatos, según el medio en el que se publique pueden ser carteles, portadas, envases, página de revista, etc. Por lo que su principal característica es su inmediato impacto visual. Aquí se considera (a) las ilustraciones de moda, (b) las ilustraciones de envases, (c) las imágenes comerciales, etc.

- $\quad$ Ilustración científica.

Según Sanmiguel y Ubach (2014, p. 18), la ilustración científica es: Uno de los medios más efectivos de exponer informaciones precisas y detalladas acerca de temas que requieren un importante apoyo visual. A pesar de la moderna tecnología a disposición de los profesionales, la ilustración científica es una de las áreas en las que los avances de la reproducción fotográfica no han conseguido desbancar el trabajo del ilustrador gráfico.

- $\quad$ Ilustración técnica. 
Los adelantos de la técnica y de las ciencias en general exigen representaciones claras que sean verdaderamente útiles como referencia fiable del mecanismo, los componentes y las funciones específicas de una máquina, un organismo o un sistema natural. (Sanmiguel y Ubach, 2014, p. 20),

Este tipo de ilustración debe guardar claridad y legibilidad de la información que transmite. Cada detalle guarda una forma y tamaño proporcional, y debe ser a su vez visualmente atractiva.

\section{e. Técnicas de ilustración.}

Existen diversas técnicas que se pueden emplear para la creación de ilustraciones, a continuación, se detalla las principales técnicas empleadas hoy en día.

- Ilustración a tinta.

- Ilustración con acuarelas.

- Ilustración con rotuladores.

- Ilustración con pasteles.

- Ilustración con lápices de colores.

- Ilustración con acrílico.

- Ilustración con óleo.

- Ilustración con collage

- Ilustración con fotomontaje.

- Ilustración a tres dimensiones

- Ilustración en relieve

- Ilustración digital 


\subsection{Estado del Arte}

A continuación, se alega aspectos más relevantes de proyectos o investigaciones relacionadas con el presente proyecto de investigación.

\section{A. Internacionales.}

De tal manera, en un plano internacional podemos rescatar los siguientes proyectos o investigaciones.

\section{a. Libro ilustrado “Abuelos".}

Es un álbum ilustrado escrito por Chema Hera e ilustrado por Rosa Osuna. Un cuento para todo tipo de edades, que fue publicado por la editorial Kalandraka en el 2002 y fue galardonada con el Premio Llibreter en el 2003.

La historia se centra en una pareja de ancianos que, con delicadeza, ingenio y emotividad busca romper algunos aspectos sociales establecidos acerca de la ancianidad, abordando la imagen de las personas mayores y la autopercepción del paso del tiempo.

Por otro lado, lo textual es reforzada por ilustraciones en acuarela con un estilo sencillo y expresivo, empleando colores suaves para resaltar a los personajes y dibujos lineales para recrear recuerdos que intensifica la historia.

\section{b. Libro ilustrado "Miedos y otros Monstruos".}

Es un proyecto de Aida Valugo Ramírez, quien representa cuatro miedos: ornitofobia, talasofobia, escotofobia y los sustos, en diferentes criaturas que interactúan con el personaje principal, con el fin de enseñar al público infantil que los miedos no son tan terroríficos como uno se lo imagina.

Además, la autora emplea el formato acordeón para convertir el libro en un desplegable donde el lector puede interactuar y ser parte de la aventura del personaje por los distintos escenarios del cuento. (Artediez, 2019) 


\section{B. Nacionales.}

En un ámbito nacional, podemos rescatar los siguientes iniciativas, programas o campañas.

a. Historias Gráficas en el Centro Histórico de Lima: Identidad Cultural de Barrios Altos.

Este concurso se desarrolló en el 2017 y fue organizado por la Dirección de Promoción Cultural de la Escuela Nacional Superior Autónoma de Bellas Artes del Perú (ENSABAP), el Centro de la Imagen, el Instituto Cultural Peruano Norteamericano (ICPNA) y que contó con la participación de duplas intergeneracionales conformadas por estudiantes o egresados de Bellas Artes y adultos mayores residentes de Barrios Altos, quienes debían compartir un relato que sería graficado por el artista de Bellas Artes.

El concurso busco promover la valoración del patrimonio cultural inmaterial de Barrios Altos, esto debido a la situación crítica en la que se encontraba. Así mismo, contó con una exposición como resultado del concurso, donde se presentó las obras realizadas por las duplas intergeneracionales y se premió a los ganadores. De tal forma esta iniciativa, logró reconocer la importancia de las personas mayores como pieza fundamental en la memoria colectiva de la sociedad.

\section{b. Proyecto “Libro Infantil”.}

Este proyecto inicia en 2006, por la Asociación Cultural Peruana Alemana en Cusco (ACUPARI), quienes buscaban fomentar la lectura en los niños de las zonas rurales de comunidades andinas, los cuales no contaban con mucho material didáctico de literatura infantil. 
Un año después, lanzaron el “Concurso Regional del Cuento Infantil”, el cual contó con 89 participantes en la creación literaria y 14 artistas presentaron sus ilustraciones. Cuyo ganador fue el cusqueño Braddy Romero, autor del cuento “Catalina y la Unkuña Mágica”, historia que enseña la relación que existe entre “texto" y “textiles", escrita en español y quechua y que fue compartida con los niños andinos.

Hoy en día, ACUARI ya ha publicado "Los Cuentos de mi Abuela", narrados en quechua por una anciana cusqueña, y "Kantu y Quenti" que cuenta una amorosa relación entre el picaflor y la flor andina kantu, cuentos bilingües entregados a las escuelas rurales de las provincias andinas del Cusco. 


\section{Capítulo II}

\subsection{Análisis del Público Objetivo}

El actor elegido para abordar el problema es la comunidad de Santa Isabel, Arias citado en Causse $(2009$, p. 3$)$ define a la comunidad como "grupo de personas que viven en un área geográficamente específica y cuyos miembros comparten actividades e intereses comunes, donde pueden o no cooperar formal e informalmente para la solución de los problemas colectivos".

De tal manera, la comunidad de Santa Isabel lo conforman todas las personas que viven en la Urbanización del mismo nombre y cuyos miembros son niños, adolescentes, jóvenes, adultos y personas mayores, así como también, familiares, amistades y vecinos que interactúa con los actores discriminados (personas adultas mayores) en su vida diaria.

Para un mejor entendimiento se dividió en dos bloques a los principales actores que encontramos en la comunidad:

- Los discriminados, que lo conforman las PAM de la comunidad.

- Los discriminantes, conformado por todas las personas que interactúan con las PAM.

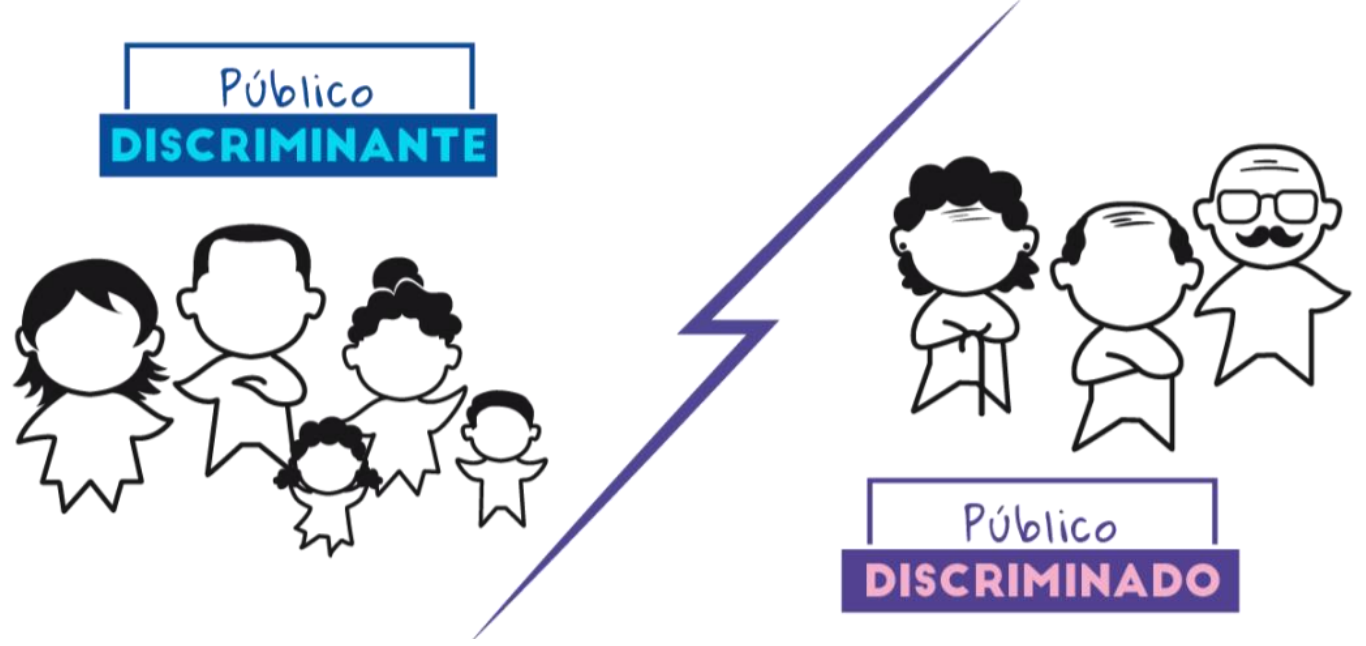

Figura 5. Públicos objetivos. Elaboración propia. 
De acuerdo, al resultado de las encuestas y entrevistas realizadas, los jóvenes perciben la vejez como una etapa en la que se pierden los atributos positivos asociándolos a una valoración negativa.

De tal manera, se eligió del público discriminante a las personas que oscilan entre los 15 a 30 años, de un nivel socioeconómico C y D, que viven en Lima Norte. Jóvenes que vienen desarrollando una imagen negativa de la vejez a raíz de los estereotipos y prejuicios que reproduce nuestra sociedad hacia las personas mayores. Jóvenes que no piensan que en un futuro también envejecerán y deberán enfrentar esa etapa con sus propios estereotipos y prejuicios.

\subsection{Descripción del Proyecto de Diseño}

El proyecto social busca promover la revaloración de la población adulta mayor para su reconocimiento como el tesoro de la sociedad. De tal forma, permitirá revalorizar la experiencia, el esfuerzo y las habilidades de aquellos que poseen el conocimiento de toda una vida.

No es casualidad que, para las antiguas culturas, las personas mayores representaban sabiduría y eran los encargados de transmitir las experiencias del pasado. Por lo que se les atribuía un rol primordial, alguien a quien recurrir para encontrar consejos, guías, orientaciones y hasta decisión. Por lo que se les honraba, respetaba y apreciaba en todos los ámbitos de la vida. Sin embargo, hoy en día, el rol de las personas mayores queda relegado al confinamiento del hogar, asilo, o dependencia, donde los estereotipos y prejuicios establecidos por la sociedad e influenciada por los medios de comunicación y publicidad, han hecho que las personas tengan una imagen negativa de los PAM. Por ello, tienden a confundir vejez con decadencia o enfermedad, dándoles pocas posibilidades de reconocimiento y oportunidades de desarrollo personal y social. Vivimos en una sociedad que da primacía a 
una juventud que tienden a asociarla con productividad, belleza y éxito, mientras que la edad es vista erróneamente como un desvalor en la persona adulta mayor.

Ante esto, es importante redefinir el rol de los PAM en la sociedad, en la comunidad y en la familia como personas que aportan conocimientos y experiencias, así también, como transmisores de tradiciones y valores intergeneracionales con un legado para compartir y difundir. Y, como un tesoro de la sociedad, hay que darle la valoración que con el tiempo se ha ido perdiendo.

De ahí, que el proyecto busca dar solución al problema identificado en el distrito de Carabayllo, por lo que el presente proyecto, es el instrumento para concientizar a los jóvenes sobre las conductas discriminatorias que son influenciadas por los estereotipos y prejuicios de la vejez, que condicionan a las personas mayores.

El proyecto abarca tres fases, la primera fase consta de la recopilación de historias de las PAM, en el cual se intervendrá diversos espacios públicos para recopilar historias por medio de entrevistas a diversas personas mayores de la urbanización que quieran transmitir su historia a las nuevas generaciones. Para luego seleccionar algunas historias que serán convertidas en un cuento, acompañadas por ilustraciones que permita narrar la historia de vida.

Como segunda fase, está la mini campaña de intriga, enfocada a consultar la imagen que tienen los jóvenes de la vejez e informar al público sobre la problemática con datos reales a través de una red social de su preferencia (Instagram).

Como tercera fase, está la presentación del cuento, enfocada a despertar empatía del público, a través de un cuento ilustrado basado en historias reales de personas mayores. Estas historias serán compartidas al público de forma virtual a través de una reunión virtual por medio de la plataforma de Zoom.

\subsection{Proceso del Proyecto}




\section{a. Concepto del proyecto.}

El proyecto tiene como concepto la "revalorización del tesoro", debido a que las personas mayores son un tesoro escondido detrás de la imagen negativa de la vejez, estereotipos y prejuicios de una sociedad edadista.

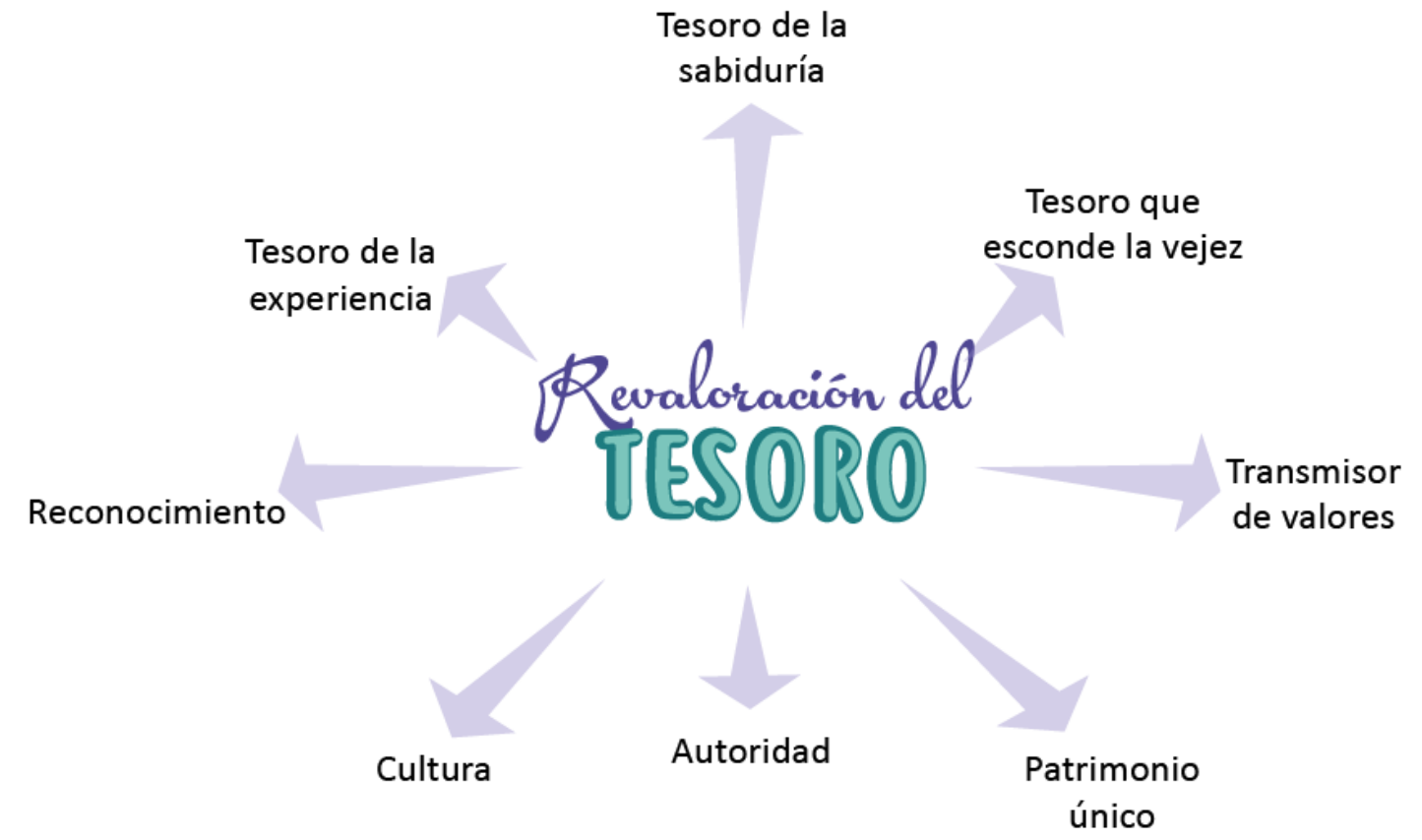

Figura 6. Concepto del proyecto. Elaboración propia.

Por lo tanto, cuando se habla de "tesoro", se hace referencia a los conocimientos, experiencias y sabidurías que tienen las personas mayores por el hecho de haber vivido varias décadas, un patrimonio único e inmaterial que cada individuo acumula a través de los años y en el transcurso del tiempo, y pese a que hoy en día la edad es vista como un desvalor en la persona, nadie puede negar el rol social que tienen los PAM en la sociedad como transmisores de valores intergeneracionales. 


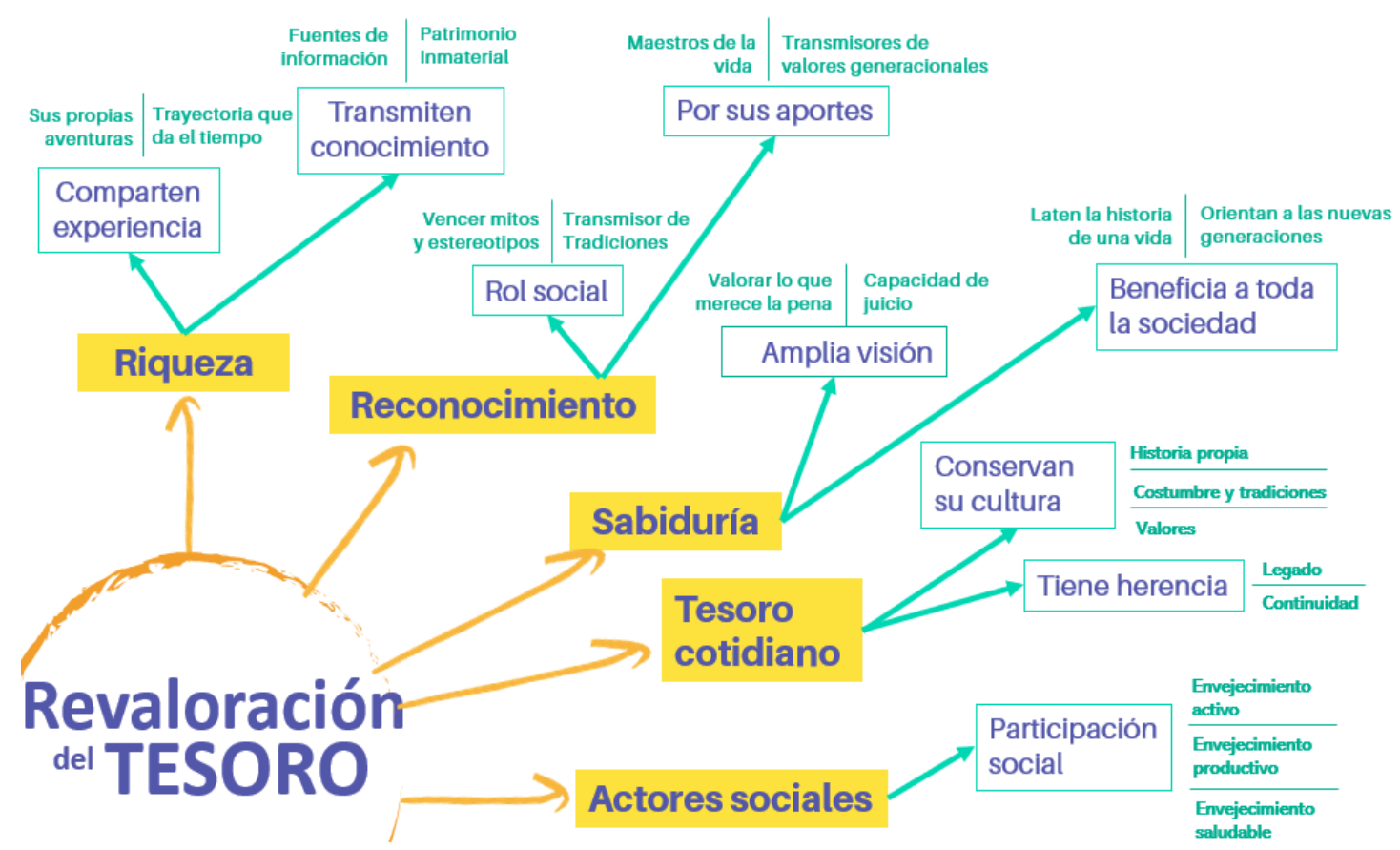

Figura 7. Análisis Conceptual Revaloración del Tesoro. Elaboración propia.

Podemos decir que las personas mayores son un tesoro oculto en la vida cotidiana, que con los años se les ha estigmatizado, marginado, abandonado, desechado y descartado de nuestra sociedad y de las actividades diarias.

Por lo tanto, el proyecto busca promover la revaloración de la población mayor a través de historias ilustradas de personas mayores, que transmitan valores intergeneracionales, que oriente desde la experiencia y conocimiento de toda una vida a los jóvenes. Aportando conocimientos para combatir los mitos y prejuicios con relación al imaginario de la vejez, contribuyendo así, a construir una imagen positiva de la vejez, revalorizando la experiencia, el esfuerzo y las habilidades de aquellos que poseen los conocimientos de toda una vida, reconociéndolos así como el tesoro de la sociedad. 

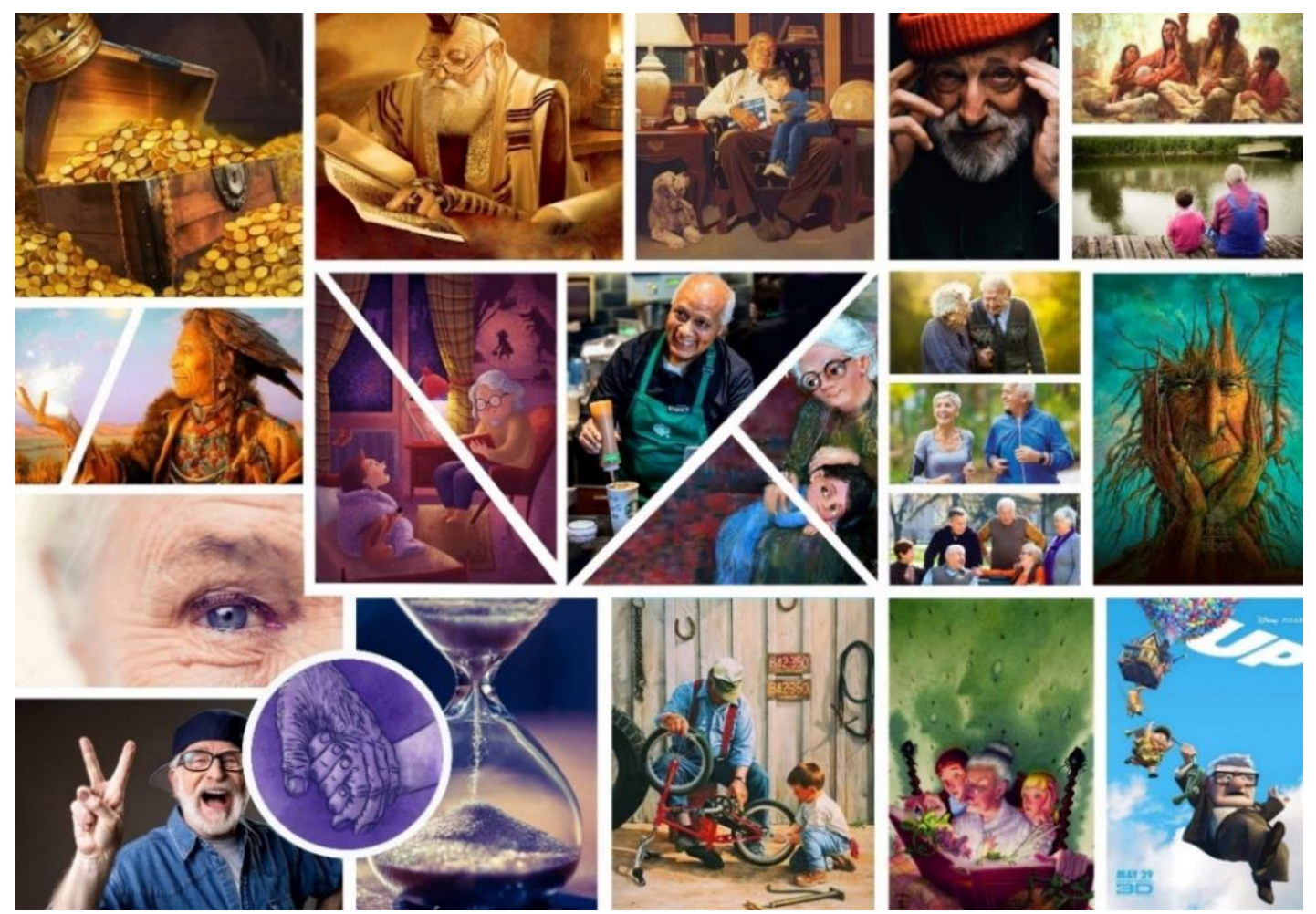

Figura 8. MoodBoard del concepto "Revaloración del Tesoro". Elaboración propia.

\section{b. Nombre del proyecto.}

El nombre del proyecto es "Tesoros de vida", debido a que este proyecto social recurre a rescatar el valor de las personas mayores por la relevancia de sus aportes y beneficios que ofrecen a la sociedad, como transmisores de valores intergeneracionales, que permitan orientar y educar desde la experiencia y el conocimiento del pasado a las nuevas generaciones.

Según la Real Academia Española (RAE), en su tercera acepción referente al termino "tesoro", lo define como "persona o cosa, o conjunto o suma de cosas, de mucho precio o muy dignas de estimación.", de tal manera, nos referimos con este término a las personas mayores, que pese a que con los años se ha perdido su lugar en el mundo, son un tesoro de sabiduría, reverenciado por su trayectoria temporal, su experiencia y por el talento acumulado que transmite y hereda a las nuevas generaciones. Un tesoro escondido detrás de la imagen de la vejez, que traslucen una 
actitud vital fruto de la madurez, que aportan ciencia y técnica no disponible en internet, con conocimientos y talentos especiales que solo los da el tiempo. Un tesoro de la experiencia acumulada que puede iluminar a las nuevas generaciones, legando valores, recuerdos y lecciones aprendidas para que estos puedan formar capacidades, habilidades, conocimientos y valores propios que les permita poder aprender y comprender a cada persona sin juzgar o discriminar. Logrando crear un mejor vínculo intergeneracional entre la familia, la comunidad y la sociedad.

Cuando hacemos referencia al término "vida", desde una definición filosófica del término, es un conjunto de experiencias acumuladas a través de los años y por el transcurso del tiempo.

\section{c. Fundamentación del proyecto.}

El proyecto tiene como objetivo promover la revaloración de la población adulta mayor en los jóvenes, de tal manera, se plantea redefinir el rol de las personas mayores como transmisores de valores intergeneracionales, que permitan orientar y educar desde la experiencia y el conocimiento del pasado a las nuevas generaciones. Logrando crear un mejor vínculo intergeneracional entre la familia, la comunidad y la sociedad, contribuyendo así a combatir los mitos y prejuicios de la vejez y por ende, se busca aportar con conocimientos para construir una imagen positiva de la vejez en la sociedad.

De tal manera, se busca que los jóvenes replanteen sus creencias estereotipadas y prejuicios acerca de la vejez, que solo limita y condiciona a las personas adultas mayores. Que dejen de ver la edad como un desvalor en la persona mayor, y, por el contrario, los valoren más por el patrimonio inmaterial y huellas que deja en la sociedad, legando valores intergeneracionales en los jóvenes para que puedan formar 
capacidades, habilidades, conocimientos y valores propios que les permita poder aprender y comprender a cada persona sin juzgar o discriminar.

Es así como el público, luego de ser aleccionado por el proyecto, contribuirá a construir una imagen positiva de la vejez, fortaleciendo el rol de los PAM en las familias, comunidades y sociedad con el fin de recuperar y revalorar sus experiencias de vida.

\subsection{Diseño de la Comunicación.}

\section{a. ¿Cómo llegamos a este público?}

El método de generar interés en nuestro público será a través de un tono informativo, debido que se busca brindar información sobre el problema del edadismo, así mismo, tendrá un tono emocional e inspiracional.

\section{b. ¿Cómo logramos que entienda el mensaje?}

La idea fundamental del mensaje será comunicada a través de un cuento ilustrado que narre historias de vida de personas mayores. Por ello guarda un lenguaje claro, sencillo y sin ambigüedades, evitando las palabras complicadas o analogías complejas, con frases bien estructuradas. Con un contenido gráfico que va más alla de trasos y dibujos, por lo que, la ilustración juega un papel relevante en el diseño del cuento, como herramienta de comunicación.

\section{c. ¿Cómo nos aseguramos en despertar su interés?}

Se logrará captar su atención con la técnica de ilustraciones, a mano alzada, combinado con la aplicación de color en acuarela digital para aportar profundidad y dinamismo. Debido a ello, el contenido ilustrado permite al lector interpretar el texto más allá de las palabras, cobrando un atractivo especial para el público lector.

d. ¿Cómo lograremos que el mensaje perdure en el tiempo? 
El proyecto está compuesto por tres fases, la primera consta en recopilar las historias de vida de las PAM, la cual se realizará a través de entrevistas. La segunta consta de una campaña de intriga, la cual se va a realizar a través de las redes sociales, la tercera es la presentación del cuento a efectuarse a través de una reunión digital. Así mismo, está etapa está compuesta por una serie de piezas gráficas que permitirá un mensaje efectivo y fácil de entender, la recordación por parte del público, donde deberá generarle confianza y ser creíble para tener efectividad, dentro de lo que el consumidor considere factible y viable. Entre las principales piezas, esta: un video testimonial de las PAM, que recopilará una serie de testimonios de personas mayores sobre la imagen de la vejez, los estereotipos y prejuicios que existen en la sociedad que los limita. Así mismo, se contará con un cuento que contiene una serie de ilustraciones de historias de vida de personas mayores como transmisores de valores intergeneracionales, que serán difundida virtualmente.

Por lo tanto, se contará con estímulos que resulten familiares para el público objetivo, con varios elementos visuales para facilitar la recordación, y mensajes emocionales para que perdure en el tiempo.

\section{e. ¿Qué medios se utilizarán, impresos, digitales, audiovisuales, interactivos?}

Se empleará medios digitales, como la plataforma de Zoom, por donde se presentará el cuento digital. Así mismo, se contará con una red social, la cual tendrá un rol importante promocionando el proyecto, transmitiendo información e interactuando con el público. Para ello se creará una cuenta de instagram, en ella, se publicarán post informativos con datos estadísticos, encuestas interactivas y videos con las percepciones del público respecto a la imagen de la vejez y del PAM.

\section{f. ¿Qué etapas de comunicación tiene el proyecto?}

El proyecto consta de tres fases, cada una de ellas representa un enfoque distinto. 


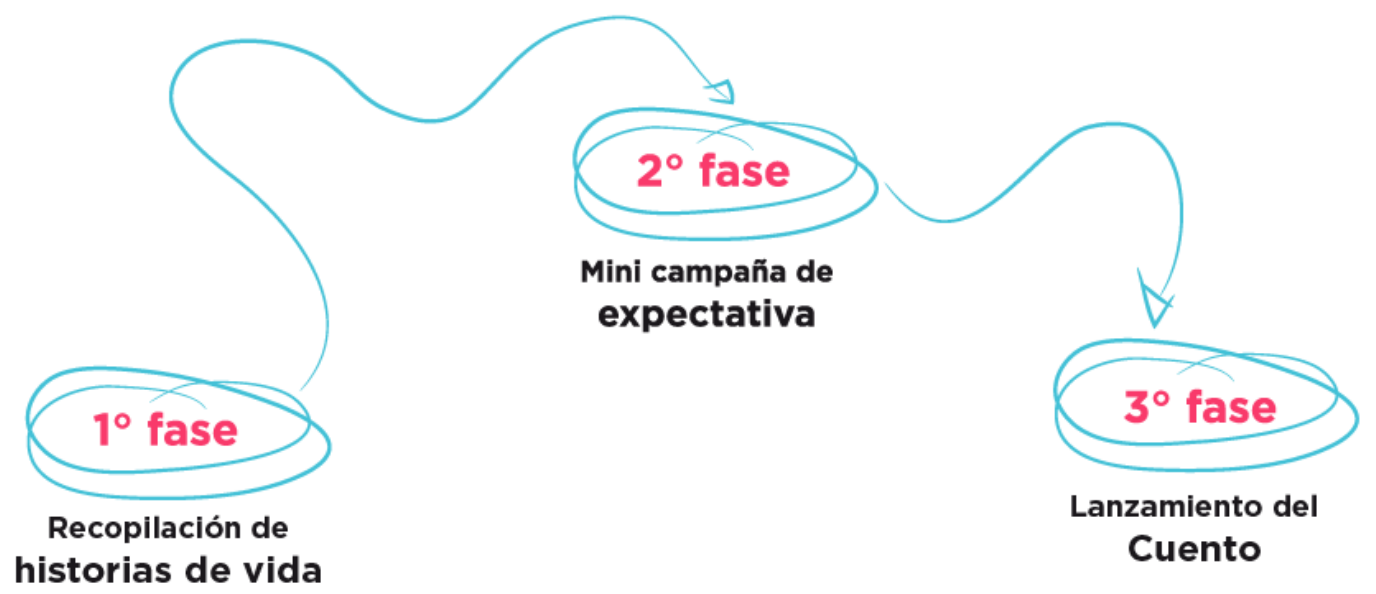

Figura 9. Fases del proyecto. Elaboración propia.

- Primera fase: Recopilación de historias de las PAM

En esta primera fase se intervendrá diversos espacios públicos para recopilar vivencias por medio de entrevistas a diversas personas mayores de la urbanización que quieran transmitir su historia a las nuevas generaciones. Para luego seleccionar algunas historias que serán convertidas en un cuento, acompañado por ilustraciones que permitan narrar la historia de vida.

- Segunda fase: Mini campaña de intriga

Dirigida a informar al público la problemática con datos reales. Por lo que, a través de la red social de su preferencia (Instagram) se busca contactar con el público e informar sobre la problemática con datos relevantes. Se empleará post informativos, videos, hashtags y encuestas para generar mayor interacción. Así mismo, se intervendrá un área pública para conocer la opinión de las personas acerca de la imagen de la vejez, los cuales serán transmitidos en redes sociales.

- Tercera fase: Presentación del cuento

Enfocada a despertar la empatía del público, hacerles ver que las personas mayores poseen conocimientos y experiencias por el hecho de haber vivido varias 
décadas, y ser reconocidos como patrimonio único e inmaterial que cada individuo acumula a través de los años y en el transcurso del tiempo. Por lo tanto, revalorar el rol social que tienen los PAM en la transmisión de valores intergeneracionales.

A través de las redes sociales se pretende promover el proyecto "Tesoros de Vida”, a través de diversos posts informativos, así mismo se invitará a la presentación del cuento, que se realizará de forma virtual, a través de la plataforma de Zoom, dándole al público la oportunidad de interactuar con la pieza editorial, se tomará registro de las reacciones e invitará a que el público exprese su reflexión acerca de la historia ilustrada.

\section{Receptor}

Para la realización del proyecto se seleccionó como público objetivo las personas que oscilan entre los 15 a 30 años, de un nivel socioeconómico C y D, que viven en Lima Norte. Jóvenes que vienen desarrollando una imagen negativa de la vejez a raíz de los estereotipos y prejuicios que reproduce nuestra sociedad hacia las personas mayores.

\section{Perfil del público objetivo:}

\section{Perfil demográfico}

- Sexo: Hombres y mujeres

- Edad: 15 - 30 años

- N.S.E.: C, D

- Personas que viven en Lima Norte

\section{Perfil psicográfico}

- Personas emprendedoras, buscan salir adelante, y son optimistas respecto a la mejora de su situación económica. 
- La mayoría cuenta por lo menos con formación básica secundaria, profesional o técnica.

- Tienen una vida muy activa, por lo que realizan ocupaciones laborales, estudio, compras, etc.

- Viven acelerados, a su propio ritmo y con prisa.

- Se movilizan principalmente dentro de la ciudad para ir a su trabajo, oficina o centro de estudios con transportes públicos como combi, coasters, buses, colectivos y mototaxi.

- Son personas que les gusta asistir a centros comerciales y parques para pasear, les agrada ir a cines, realizan compras en tiendas por departamento. Por lo que les encantan las promociones, ofertas y obsequios.

- Son personas que dedican su tiempo a usar dispositivos electrónicos como teléfonos móviles, tabletas, pc o laptops.

- Tienen acceso a internet por lo que cuentan con un celular, y por lo menos con alguna red social, como Facebook e Instagram.

\section{- ¿Por qué se eligió a este actor?}

Porque de todos los miembros de la comunidad que intervienen en la problemática, son los jóvenes los que tienen un pensamiento más errado respecto a la imagen que perciben de las personas mayores y de la vejez, esto debido a los estereotipos y prejuicios negativos que la sociedad inculca, dándo primacía a tantos productos antiedad, donde la juventud tiende a ser asociada con productividad, belleza y éxito, mientras que la vejez es vista por muchos como una etapa de enfermedad, discapacidad y debilidad, entre otras creencias descalificativas que solo atribuyen a distorsionar la imagen de la vejez en la sociedad, por lo que obstaculiza la integración de las personas mayores, en la sociedad, comunidad y vida familiar. 


\section{- Emisor}

La realización del proyecto y todas las fases, estará a cargo de la creadora del proyecto. Así mismo, se busca crear alianza con algunas empresas o instituciones para que financien y difundan el proyecto.

\section{- Canales y medios}

Entre los medios digitales, se eligió las redes sociales, para crear difusión e interacción con en el público objetivo, por lo tanto, se planteó como red social una cuenta de Instagram debido a que es la red social más usadas por el público. Por lo cual será una pieza clave para la difución de los mensajes. En ellas, se publicarán post informativos, videos del proyecto y testimonios de las personas mayores. Así mismo, el lanzamiento del cuento, se realizará de forma virtual, a través de la plataforma de Zoom. El cual permitá crear una interacción entre el público y el cuento ilustrado.

\section{- Mensaje}

Redefinir el rol de los PAM en la sociedad, en la comunidad y en la familia para revalorizarlas como personas que transmiten valores, conocimientos y experiencias, por el hecho de haber vivido varias décadas, un patrimonio único e inmaterial que cada individuo acumula a través de los años y en el transcurso del tiempo.

Las personas mayores son un tesoro oculto en la vida cotidiana, que con los años se les ha estigmatizado, marginado, abandonado, desechado y descartado de nuestra sociedad, sin embargo, nadie puede negar el rol social que tienen los PAM en la transmisión de valores intergeneracionales.

\subsection{Estudio de la comunicación}

\section{a. Sintaxis.}

Con respecto al diseño de las piezas gráficas se busca transmitir al público un mensaje claro y conciso, para ello se optó por un estilo gráfico que conecte con el 
público, por medio de una serie de componentes visuales como ilustraciones, colores, formas, etc., que transmitan y reflejen el concepto del proyecto. De tal manera, se busca que el público objetivo comprenda el mensaje del proyecto de manera efectiva.

Respecto a la representación visual del nombre del proyecto "Tesoros de vida", se optó por un logotipo que refleje confianza, equidad e inclusión, y una relación amigable, reflexiva e intergeneracional entre las personas mayores y los jóvenes.

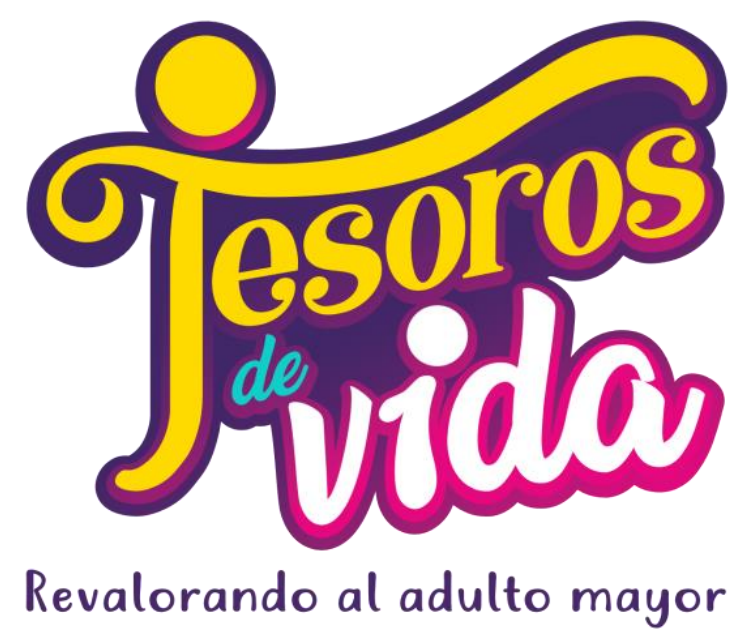

Figura 10. Logo del proyecto. Elaboración propia.
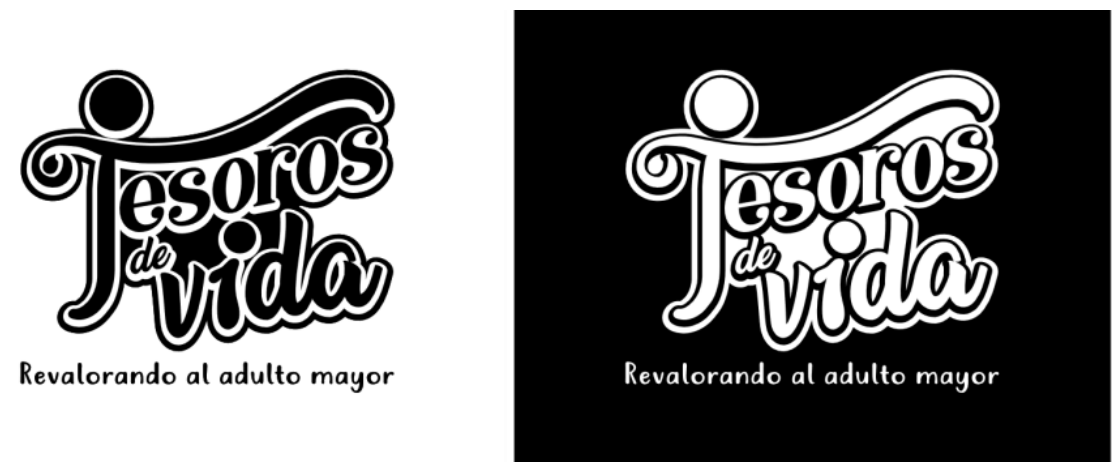

Figura 11. Logotipo en positivo y negativo. Elaboración propia.

Se personalizó las letras “t” e "i” para evocar a dos personas. La primera se encuentra abrazando y acogiendo a todo lo demás, mientras que la segunda mira y 
escucha a la otra persona transmitiendo así el vinculo intergeneracional entre las personas mayores y los jóvenes.

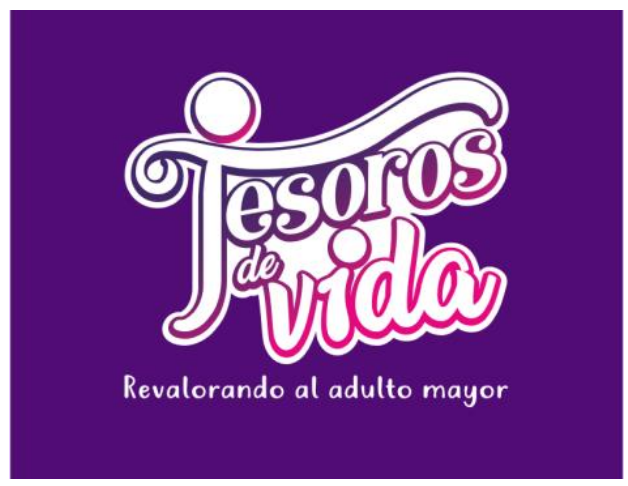

Figura 12. Logotipo a una tinta. Elaboración propia.

El logotipo está compuesto por dos tipografiás rotuladas y redondeadas, que parecen escritas a mano y reflejan cercanía. Se combinó las fuentes, tamaños de letra y grosores para personalizar la gráfica y así transmitir una relación amigable, que vaya acorde a la personalidad de la marca, moderna, social y activa. Así mismo se empleó una fuente tipográfica sin serif para el descriptor de la marca, debido a que se busca que el peso caiga en el logotipo de la marca. El descriptor hace referencia al problema que estamos abordando.

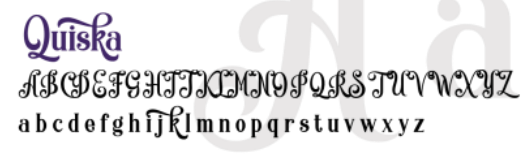

Nature Beauty Personal Use ABCDEF GAIJKLSUNOP QRSTUИWXXZ abcdelghijklmnopqrstuvwxyz

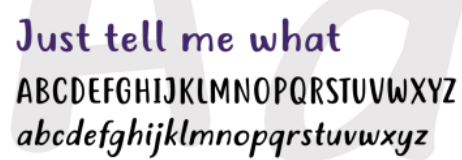

abcdefghijklmnopqrstuvwxyz

Figura 13. Paleta tipográfica. Elaboración propia. 
Se empleó una paleta de colores que vayan acorde al concepto del proyecto, donde predominan los colores alegres amarillo, morado, magenta y turqueza que buscan representar el vínculo de dos generaciones (las personas mayores y jóvenes).

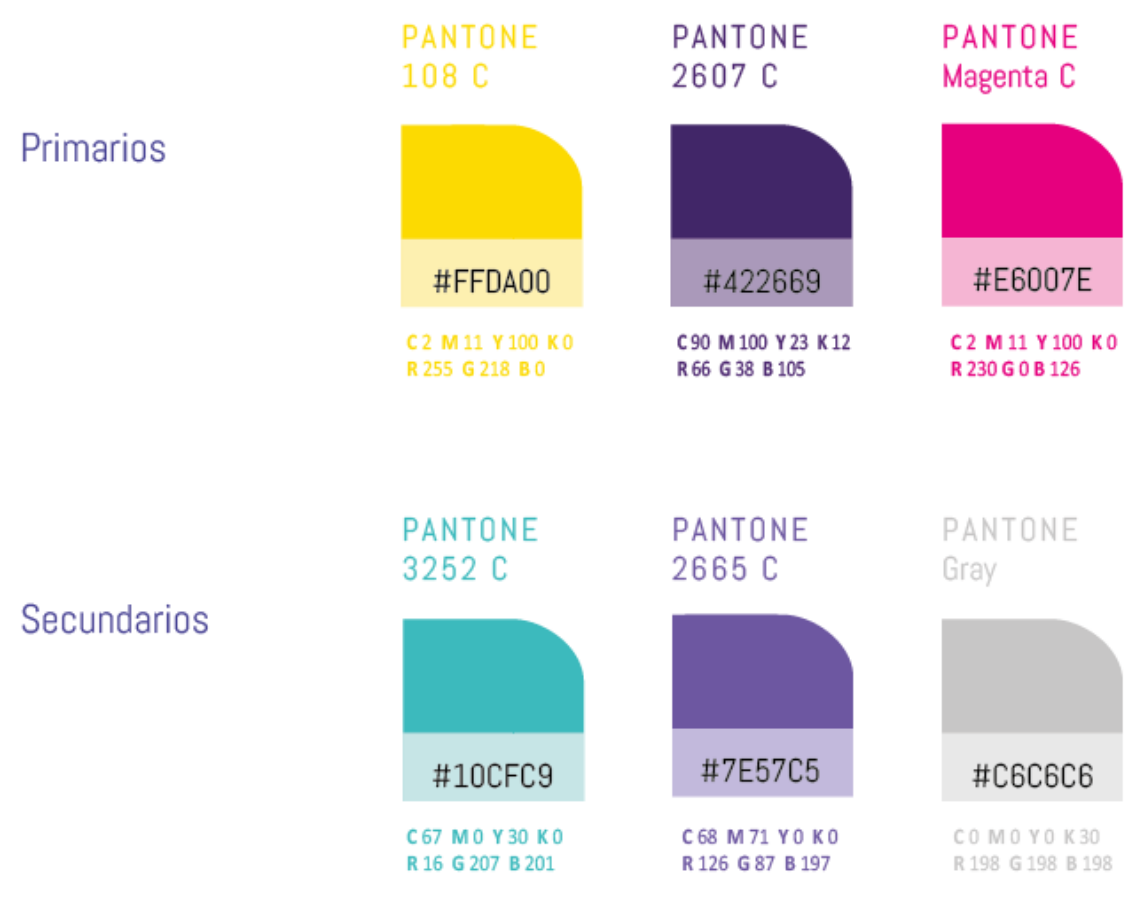

Figura 14. Paleta de colores. Elaboración propia.

\section{b. Simbología.}

El proyecto "Tesoros de vida" busca promover la revaloración de la población mayor a través de historias ilustradas de las PAM, que transmiten valores intergeneracionales al público, por ello se trabajó con el diseño del símbolo gráfico del logotipo y se personalizó las letras “t” e "i”" para transmitir el vínculo intergeneracional, de tal forma, se colocó un círculo encima de la letra " $t$ ", también se modificó el brazo y asta de la misma, convirtiéndoló en una persona que abraza y envuelve a todas las demás palabras, aludiendo así a las personas mayores, en su rol de orientar y transmitir valores intergeneracionales. En la palabra vida, se personalizó la letra “i” para crear una figura que evoque a los jóvenes. 


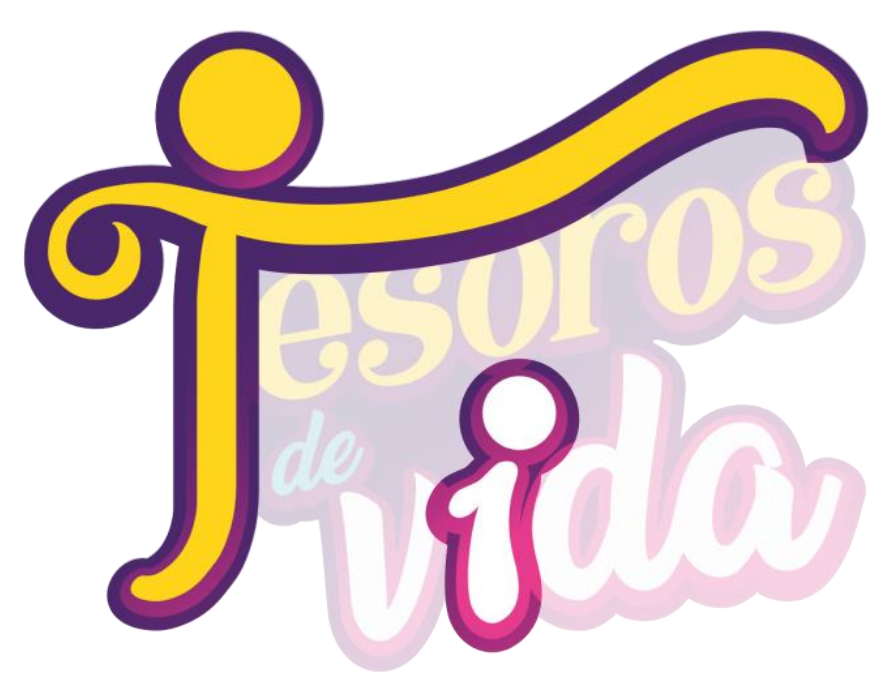

Figura 15. Símbolo gráfico. Elaboración propia.

Así mismo, los colores empleados buscan hacer referencia al rol que cumplen las personas mayores en la sociedad, de tal manera, el color amarillo que transmite alegría, calidez, amabilidad busca representar el valor y sabiduría de las personas mayores. El color morado representa el misterio y equilibrio, es el color de la reflexión, la sabiduría que las personas buscan y que lograrán con el paso de los años, por lo que, lo relacionamos con los jóvenes y el cultivar valores. El color magenta está relacionado a la bondad, compasicón y ayuda, por lo que evoca amabilidad y protección.

\section{c. Pragmatismo.}

El problema que se aborda en el presente proyecto es desconocido para la mayoría de jóvenes, por lo que se busca con la pieza diseñada informar sobre el problema desde la experiencia vivida del propio adulto mayor, para que sea entendida de una manera eficaz por el público objetivo.

La principal pieza gráfica es un cuento basado en ilustraciones que narran la historia de vida de una persona mayor entrevistada. Transmitiendo así al público los conocimientos, experiencias y valores acumulados a través de los años y en el transcurso del tiempo. Por lo tanto, está pieza permitirá crear un vínculo entre las 
personas mayores y los jóvenes, en su rol de orientar y transmitir valores intergeneracionales.

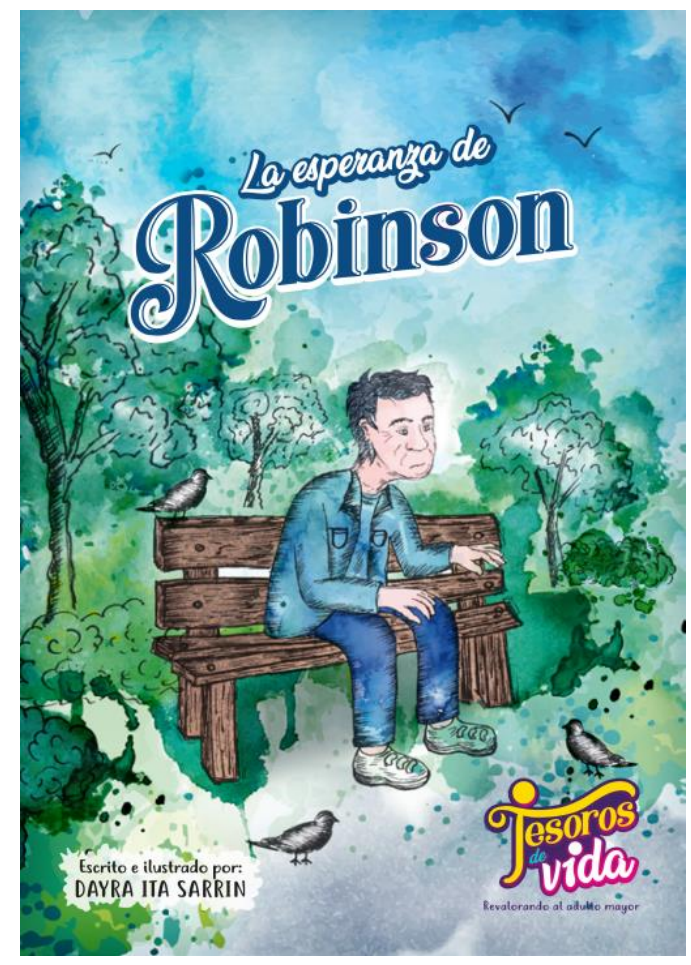

Figura 16. Portada del cuento. Elaboración propia.

Así mismo, aportar conocimientos, para combatir los mitos y prejuicios sobre la vejez, contribuyendo en la construcción de una imagen positiva.

\section{d. Estética.}

La estética del proyecto es fresca, juvenil y atractiva, con un estilo gráfico amigable y dinámico. Hace uso de la ilustración como herramienta visual principal para narrar las historias de vida de las personas mayores, y así crear empatía con el público guardando una gráfica fácil de comprender por medio de trazos sencillos y formas curvilíneas que puedan llamar la atención.

Así mismo, se emplea efectos de acuarelas que permite que la lectura visual sea fácil y rápida de asimilar, aplicando colores fríos y cálidos acordes a la trama de la historia, transmitiendo los sentimientos de los personajes. De igual forma, se empleará tramas e 
iconografías para que complementen la identidad del proyecto, los cuales serán usados en el diseño de información de varias piezas gráficas.

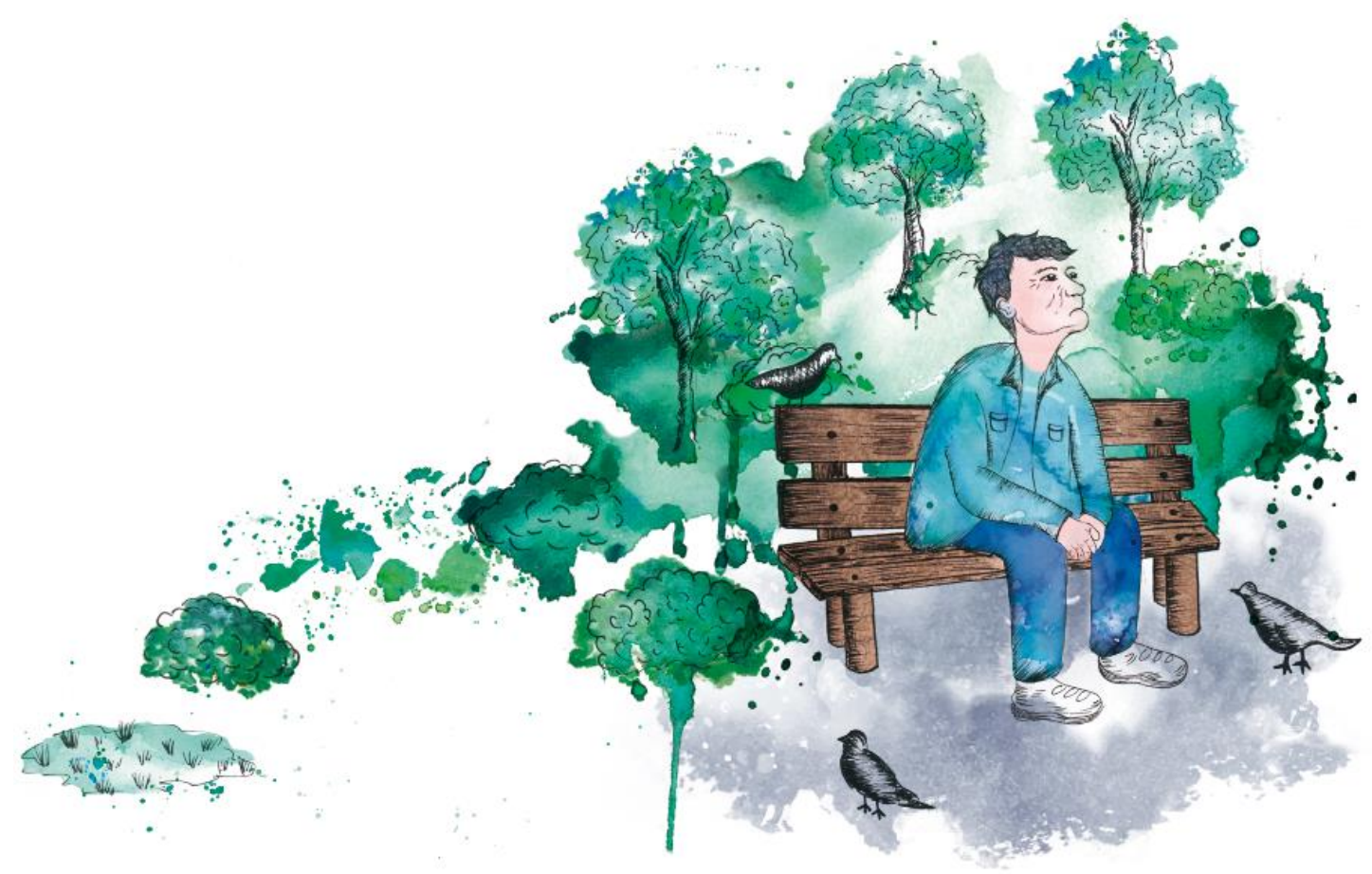

Figura 17. Estilo gráfico del cuento. Elaboración propia.

Se escogió dicha estética para captar la atención del público y la fácil comprensión del problema que se aborda, así será más amena, lúdica y dinámica la información y mensaje a transmitir en las piezas gráficas, sin llegar a ser tan pesado.

\subsection{Implementación}

La implementación se llevó a cabo por medio de cada fase del proyecto.

\section{a. Primera fase: Recopilación de historias de vida.}

Para la primera fase del proyecto se recorrió las principales calles, mercados y parques de la Urb. Santa Isabel para entrevistar a las personas mayores, dispuestas a compartir sus historias con las nuevas generaciones.

Para luego seleccionar las historias que serían convertidas en cuentos, adaptando lo narrado en un guión que posteriormente fue ilustrado. 


\section{b. Segunda fase: Mini campaña de intriga.}

En esta segunda fase se creó una cuenta en la la red social Instagram, con el objetivo de interactuar con el público, e informar sobre la problemática con datos relevantes.

En está fase, se empleó diversos post: informativo, video, encuestas interactivas, entre otros, para generar mayor interacción. Así mismo, se intervino un área transitada por el público para preguntar su opinión acerca de las personas mayores y la imagen de la vejez, que posteriormente fue publicado en la red social.

CALENDARIO EDITORIAL MES DE MARZO 2020

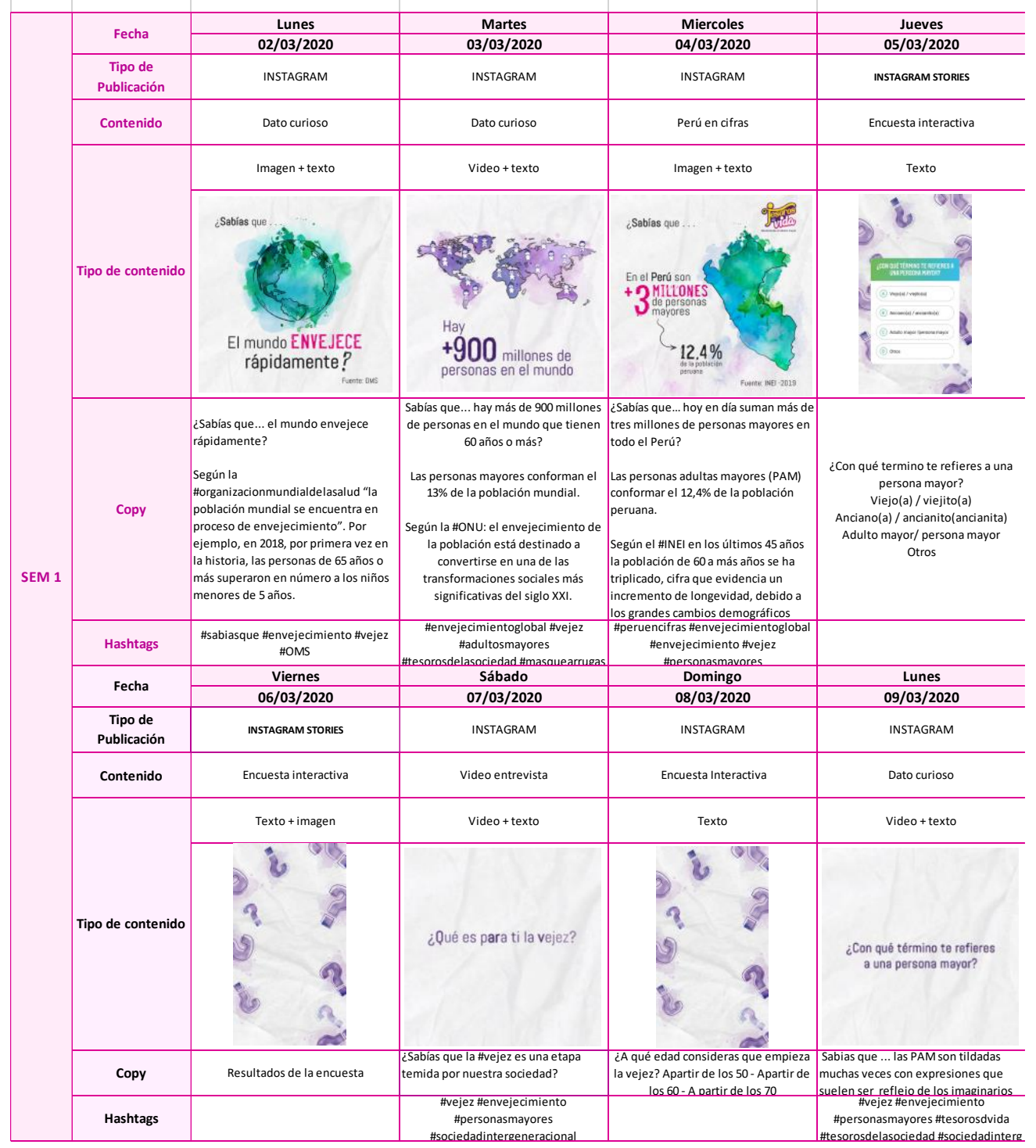

Figura 18. Calendario editorial. Elaboración propia. 


\section{c. Tercera fase: Presentación del cuento.}

Esta fase se enfoca en la presentación del cuento "La esperanza de Robinson", por lo cual, se invitará al público objetivo asistir al lanzamiento del cuento a través de un post en instagram del proyecto, que contendrá una escena del cuento, generando así intriga del lanzamiento.

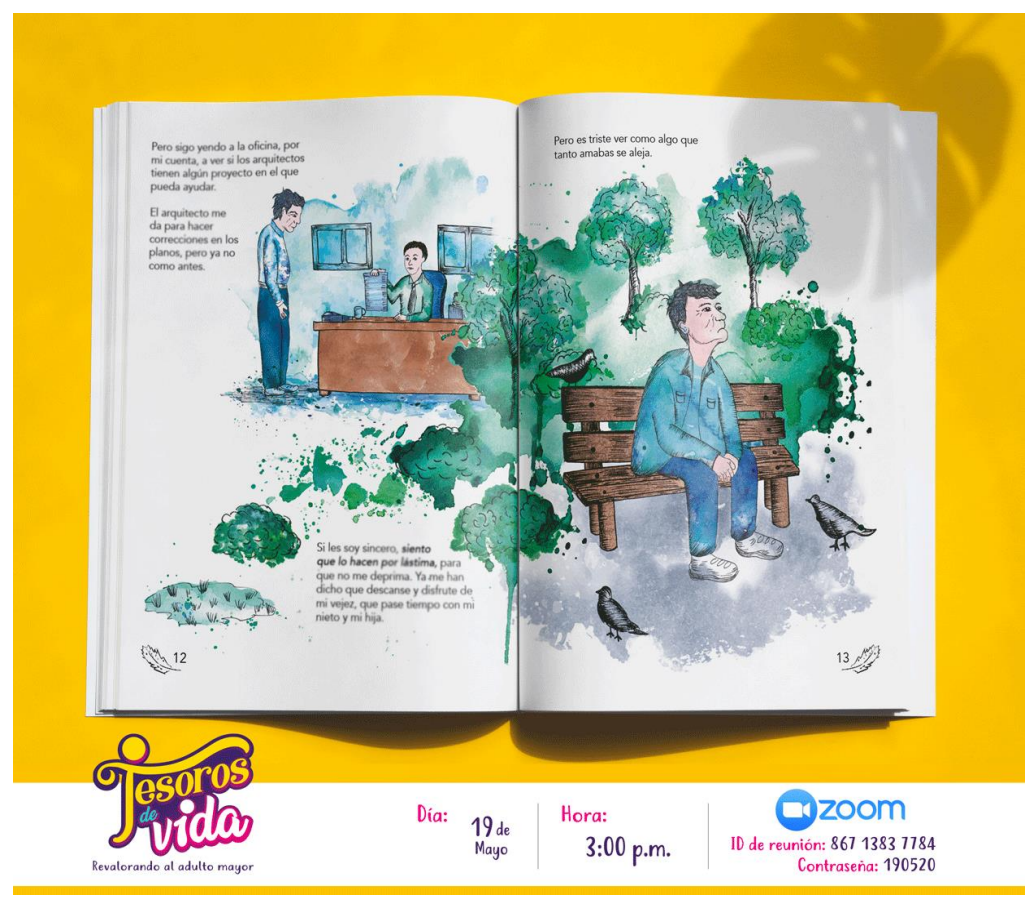

Figura 19. Invitación a la presentación del cuento. Elaboración propia.

La presentación del cuento se realizará de forma virtual, a través de la plataforma de Zoom, donde en primer lugar se pasará a presentar el proyecto "Tesoros de vida", y unos videos cortos que muestran la percepción de la gente respecto a las personas mayores y la vejez. Luego los presentes responderan tres preguntas:

- ¿Saben o han escuchado qué es el edadismo?

- ¿Hay algún miembro cercano de tu familia que sea persona adulta mayor?

- ¿Cuál sería la principal dificultad que tiene una persona adulta mayor? ¿Por qué? Luego, se pasará a leer el cuento: “La esperanza de Robinson”. 

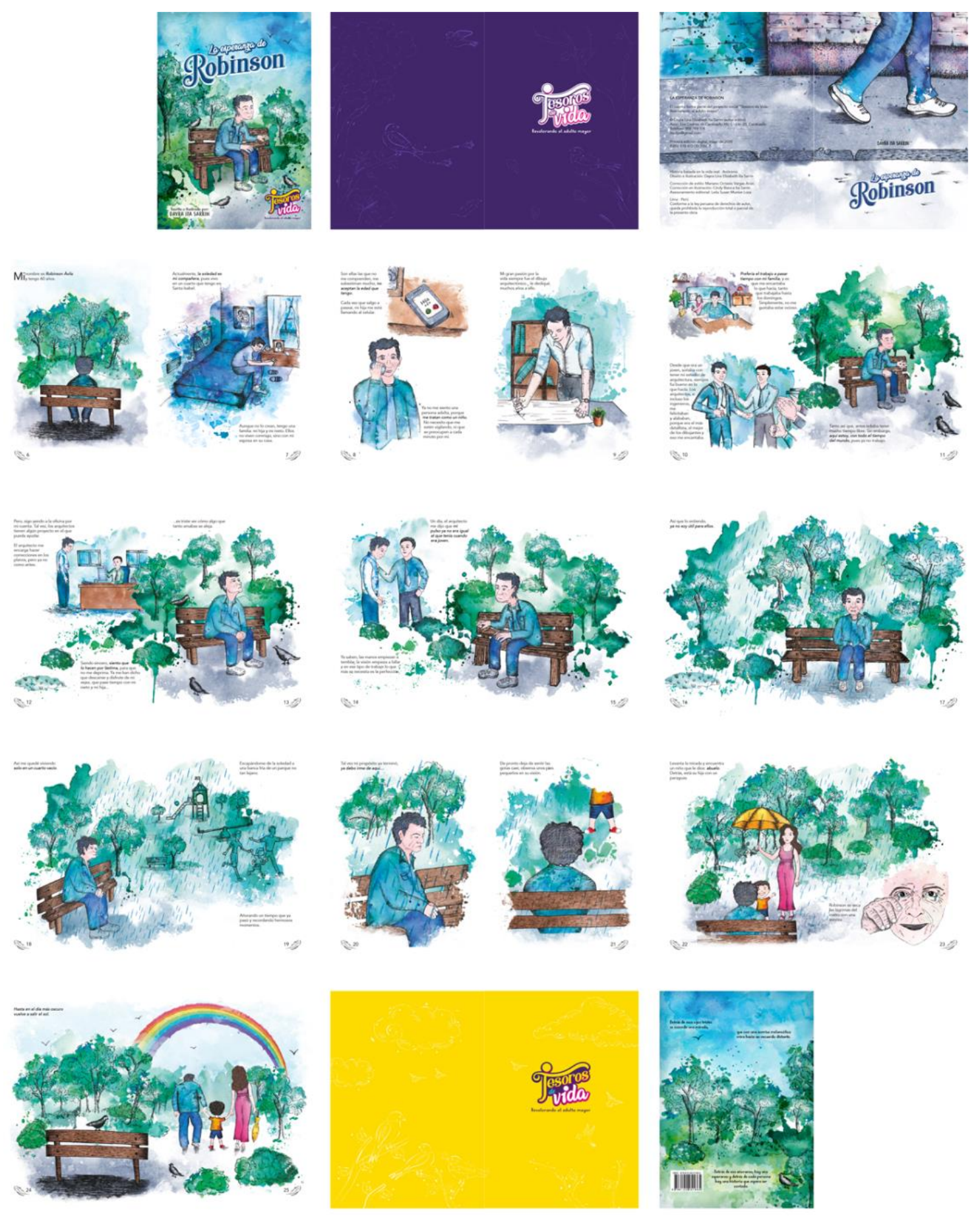

Figura 20. Pieza principal: cuento. Elaboración propia.

Posteriormente, se haran unas breves preguntas de comprensión del cuento e invitará a que el público exprese su reflexión acerca del cuento.

- ¿Con quién vive Robinson?

- ¿Cúal es la actividad que hace Robinson? 
- ¿Por qué Robinson se siente triste?

- ¿Cuál era el motivo de alegría de Robinson?

- ¿Cuál es el actual motivo de alegría de Robinson?

- ¿Qué valores encuentras en la historia?

- ¿Qué te enseña la historia de Robinson?

De tal forma, se busca que el público deje de ver la edad como un desvalor en las personas mayores y por el contrario, los valoren por el patrimonio inmaterial y huellas que deja en la sociedad, como transmisores de valores intergeneracionales. 


\section{CAPITULO III}

\subsection{Análisis de los Resultados}

\section{A. Aplicación del proyecto.}

El proyecto tuvo una duración de siete meses y fue desarrollado en tres fases.

\section{a. Primera fase: Recopilación de historias de vida.}

La primera fase del proyecto empezó en el mes de octubre del 2019 contando con una duración de tres semanas, y consistió en recorrer las principales calles, mercados y parques de la Urb. Santa Isabel para recopilar las historias de las personas mayores. Se llegó a recopilar las historias de cuatro personas mayores que fueron entrevistados.

Luego, se pasó a seleccionar el testimonio que sería convertido en cuento, adaptando lo narrado en un guion que transmita la historia de vida del adulto mayor. Así mismo, se desarrolló una escaleta para definir los escenarios y personajes que componen cada escena del cuento. Y un machote que permitió establecer los diversos elementos de cada página.

Posteriormente, se pasó a ilustrar las escenas de la historia. Está parte del proyecto, se desarrolló entre los meses de febrero y abril del 2020, contando con una duración de tres meses. Al final se realizó diecinueve ilustraciones a mano alzada. Para luego colorizar las ilustraciones de forma digital, a través del programa Adobe Photoshop dándole un estilo de acuarela a las ilustraciones. Dejando listo para pasar a diseñar y diagramar el cuento en el programa Indesing.

\section{b. Segunda fase: Mini campaña de intriga.}

Tuvo lugar en la primera semana de marzo del 2020, y se desarrolló durante la semana mencionada. Por lo que se buscó interactuar con el público a través de la red social Instagram. 
En esta fase, se empleó seis posts informativos basados en datos relevantes de la problemática. Así mismo, se realizó dos encuestas interactivas, para generar mayor atracción al tema.

Además, se compartió en la red social videos de entrevistas realizada en un área transitada por el público (Universidad César Vallejo) sobre su opinión acerca de las personas mayores y la imagen de la vejez.

\section{c. Tercera fase: Presentación del cuento.}

La tercera fase del proyecto empezó con la invitación virtual realizada un día antes de la presentación del cuento, a través de la red social Instagram. Como resultado se obtuvo: 18 interacciones de "me gusta", 0 "comentarios" y 2 “compartidos”. Así mismo, esta publicación alcanzó a 29 cuentas y tuvo 32 impresiones. Debido al poco tiempo de publicada la invitación, se decidió comunicarlo también a través del WhatsApp personal, logrando 49 vistas del estado publicado.

La presentación del cuento "La esperanza de Robinson” se desarrolló de forma virtual, el martes 19 de mayo a las 3:00 pm, a través de la plataforma de Zoom. Y contó con la participación de 23 personas.

En primer lugar, se inició con la presentación del proyecto social "Tesoros de vida", explicando brevemente cómo nace el proyecto y en qué consiste. Luego, se pasó a visualizar unos cortos videos que muestran la percepción del público entrevistado sobre la imagen de la vejez y del adulto mayor. Después, se desarrolló un conversatorio sobre tres preguntas relacionadas al problema observado en la comunidad: ¿Qué es el edadismo?, ¿Hay algún miembro cercano de tu familia que sea persona adulta mayor?, ¿Cuál sería la principal dificultad que tiene una persona adulta mayor? y ¿Por qué? 
Como consecuencia, se observó que el 91\% de los participantes nunca habían escuchado del término "edadismo", por lo que desconocían sobre este tipo de discriminación. Mientras que, solo el 9\% de los participantes conocían o tenían alguna referencia del término. Así mismo, la mayoría de los participantes indicaron que algunos de los miembros de su familia es adulto mayor, dentro de los cuales se identificó como sus abuelos, padres y/o tíos. Por lo tanto, consideran que la principal dificultad que tiene una persona mayor está relacionado principalmente a un aspecto psicológico y social, debido a la perdida de contacto social con los propios hijos y familiares, y la depresión que enfrentan al tener que adaptarse a la jubilación. Y en un aspecto biológico, a medida que empieza a deteriorarse la salud.

En segundo lugar, se presentó el cuento "La esperanza de Robinson” y se pasó a leerlo en voz alta mientras que los participantes visualizaban el cuento en la pantalla compartida. Se optó por esta forma dinámica de lectura, para llamar su atención y mantenerlos interesados en la historia.

Al término de la lectura se realizó una serie de preguntas referentes al cuento, para conocer su compresión de la historia. De esta manera, se logró comprobar que los participantes lograron prestar atención y comprender la historia. Finalmente, se solicitó la opinión de los participantes referente al cuento, para conocer el mensaje que interpretaron de la historia de Robinson, y conocer si se cumplió los objetivos del proyecto.

Además, se gestionó el número de identificación internacional, ISBN (sistema internacional de numeración de libros) y el código de barras del cuento "La esperanza de Robinson" a través de la plataforma digital de la Biblioteca Nacional del Perú. 


\section{B. Evaluación del proyecto.}

Cada fase fue necesaria para el desarrollo del proyecto. Sin embargo, pudo haberse agregado una fase adicional de "diseño del proyecto", después de la recopilación de historias. Ya que esta etapa es fundamental para el proyecto, por lo que tuvo una duración de cinco meses, necesario para terminar la pieza principal.

Con respecto a la segunda fase, la campaña de intriga presentó deficiencias, debido a que no se pudo dar mayor continuidad a través de la red social elegida. Por ello, se contó con un número bajo de interacciones y poco alcance en los diversos posts publicados.

Por otro lado, ante la coyuntura actual que vive el país por el COVID 19, se limitó la implementación del proyecto. Por ejemplo, la pieza principal fue diseñada en un inicio para ser presentada de forma impresa, se presentó de manera digital. Por lo que la presentación se desarrolló de forma virtual, a través de la plataforma de Zoom. Sin embargo, debido al corto tiempo que fue publicada la invitación en Instagram, se decidió publicarlo también a través del WhatsApp de mi persona. Pese a ello, la presentación contó, en un inicio con la participación de 23 personas. Lamentablemente, debido a la limitación de la cuenta gratuita de Zoom, que ofrece la posibilidad de hacer reuniones virtuales durante máximo 40 minutos, la presentación de la pieza editorial tubo un corte inesperado, que fue solucionado rápidamente. Pese a ello, la cantidad de participantes disminuyo a 15 personas.

A continuación, se rescata algunos comentarios de los participantes:

Para mí, Robinson se siente triste porque su hija cree que el ya no puede hacer lo que antes hacía, por ejemplo, mi abuela amaba cocinar, pero por la edad ha dejado de hacerlo. Cuando alguien deja de hacer algo que le apasiona es como si se apagara uno mismo... le cortan las alas. Y eso se ve en el cuento, no dejan que 
Robinson haga lo que realmente quiere hacer. (A, Coello, comunicación personal, 19 de mayo de 2020).

Hay tres palabras claves que se desprenden de la historia: familia, autoestima y error. Familia, porque a sus 60 años, él ya está aislado, lejos de su familia, pues no los tiene cerca. Y me parece algo incorrecto, porque de qué manera tú te podrías alejar de tu abuelo o tu padre sin tomar en cuenta sus sentimientos o sabiendo que eres lo único que tiene en la actualidad. La familia repercute en la autoestima, y la autoestima está presente tanto en el ámbito laboral como el ámbito personal. El a sus 60 años [Robinson] seguía yendo a una empresa que ya no le tomaba en cuenta, pero lo hacía porque su pasión era el dibujo. Y el, intentando ayudar se sentía de una manera vivo. Y error, porque en la actualidad estamos en una sociedad que va a los dos extremos: subestimamos la juventud como la experiencia. Entonces, en este caso se subestima la experiencia, cayendo en error de no darle el valor que merece. No se trata de idolatrar, sino de valorar la experiencia que él tiene”. (L. Lévano, comunicación personal, 19 de mayo de 2020).

Para mí el tema principal es el edadismo, y se ha logrado plasmarlo en el cuento, pues a lo largo de la historia, se ve las consecuencias que tiene justamente este tema, al quedar aislado por la edad, no solamente con su familia, sino en el trabajo. No confiar en las cualidades que puede tener un adulto mayor, que en este caso son muchas. No hay que ver a las personas mayores como un estorbo o una carga. Sino verlos como personas de quien aprender, al final, así como dice el cuento, hay una luz de esperanza, y tal vez ahí nace una oportunidad para que pueda desarrollar una nueva actividad. (A. Javier, comunicación personal, 19 de mayo de 2020). 
Yo lo veo como ponerse en el zapato de este adulto mayor para poder comprenderlo [...]. Como es un caso de la vida real, para mi es de mayor impacto, porque está basado en hechos reales. Como que comprendes más a la persona y te acerca más a ella con la historia. Llevando a la revaloración del adulto mayor. [...] Finalmente, me pareció interesante poder acercarme al personaje de la historia porque comprendí sus sentimientos de esta persona. [...] Porque cuando uno entiende los sentimientos quizá lo comprende un poquito más, y al final el cuento te deja pensando. Todos vamos a llegar a esa etapa, y eso te permite revalorarlo, porque al final no quieres que eso pase con tu vida. Hay que comprenderlos más, como te gustaría que te vieran en ese futuro. (M. Checco, comunicación personal, 19 de mayo de 2020).

El proyecto “Tesoros de vida”, logró contar la historia de vida de Robinson a través de ilustraciones para concientizar sobre la discriminación por edadismo, problema que era desconocido para la mayoría de los participantes. De ahí que estos, lograran entender la importancia del rol de las personas mayores dentro de la familia, y la valiosa función social que tienen en la comunidad y por ende se vea reflejado en la sociedad. Por lo que esta iniciativa permite reconocerlos como transmisores de valores intergeneracionales con un legado de experiencias y conocimientos para compartir y difundir.

En definitiva, el proyecto cumplió su objetivo principal, al promover en los participantes la revaloración de la población adulta mayor a través de la pieza editorial diseñada. El cuento permitió revalorizar la experiencia, el esfuerzo y las habilidades de aquellos que poseen el conocimiento de toda una vida. Así mismo, reconociéndolos como el tesoro de la sociedad que con el tiempo se ha ido perdiendo.

\section{Registro de implementación.}


Primera fase: Recopilación de historias de vida.

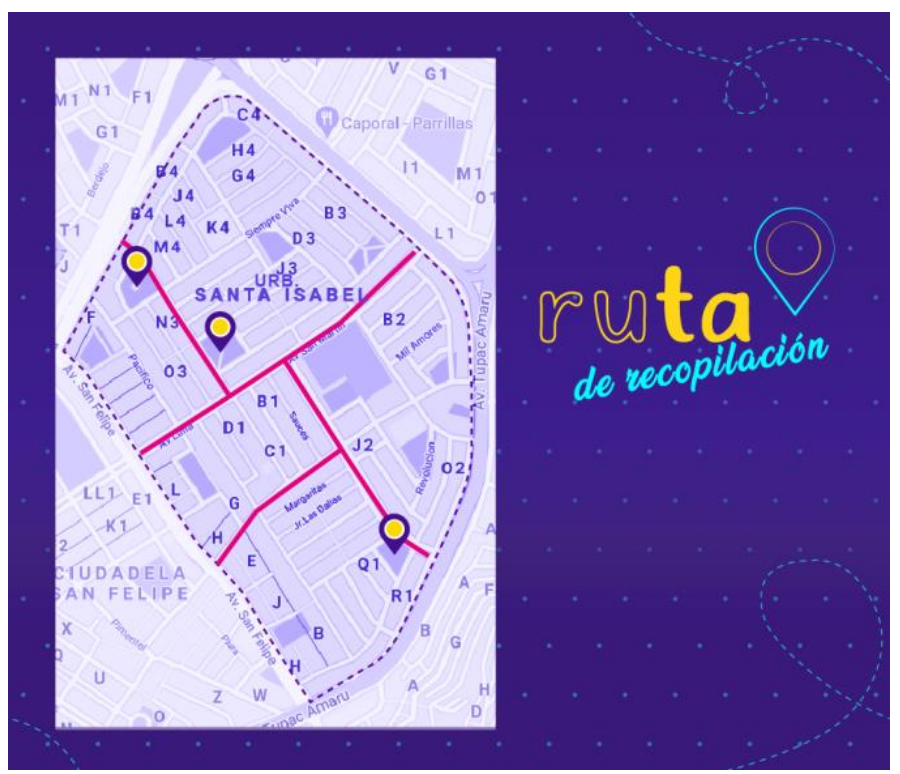

Figura 21. Ruta recorrida. Elaboración propia.

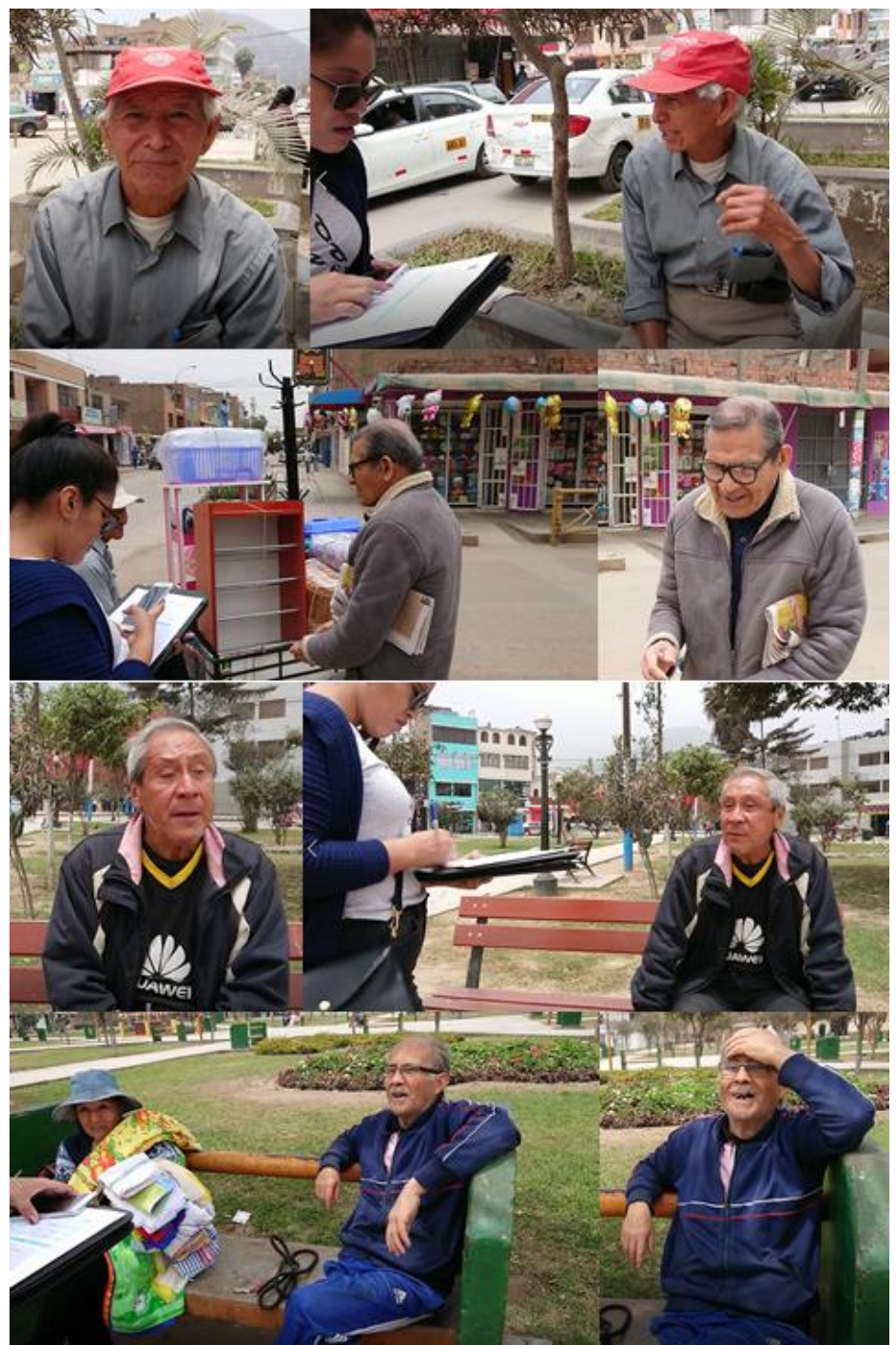


Figura 22. Entrevista a cuatro personas mayores. Elaboración propia.
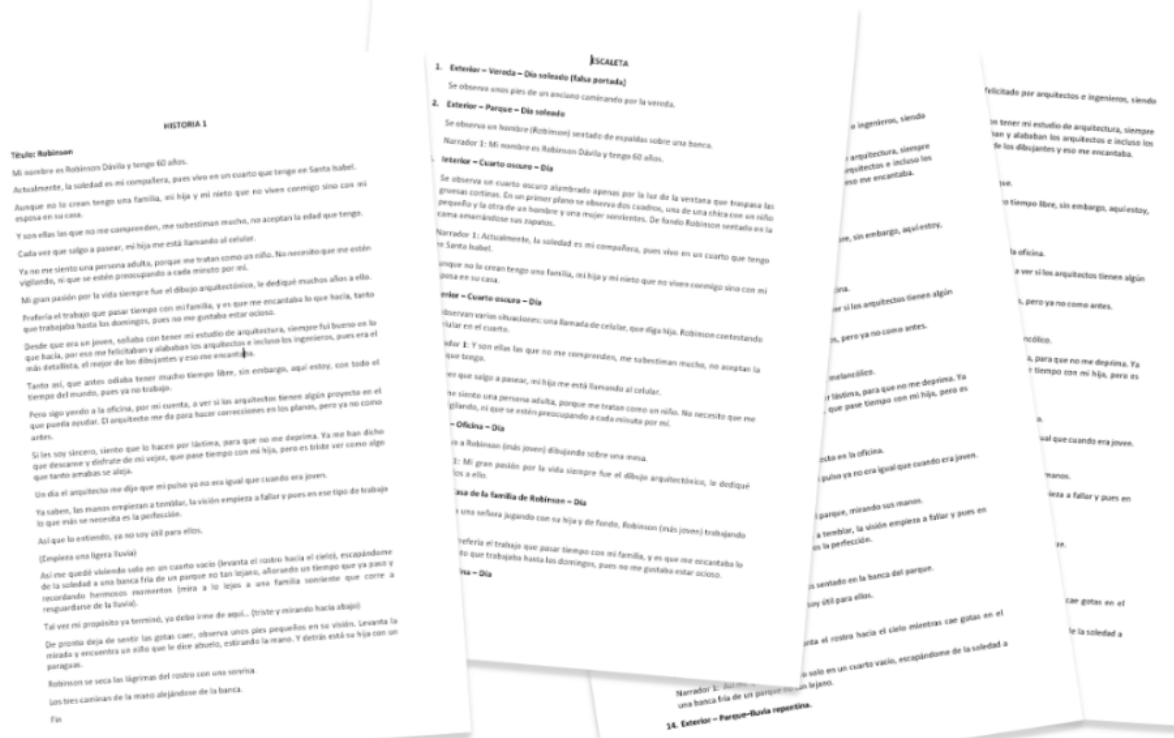

Figura 23. Guión de la historia seleccionada y escaleta. Elaboración propia.

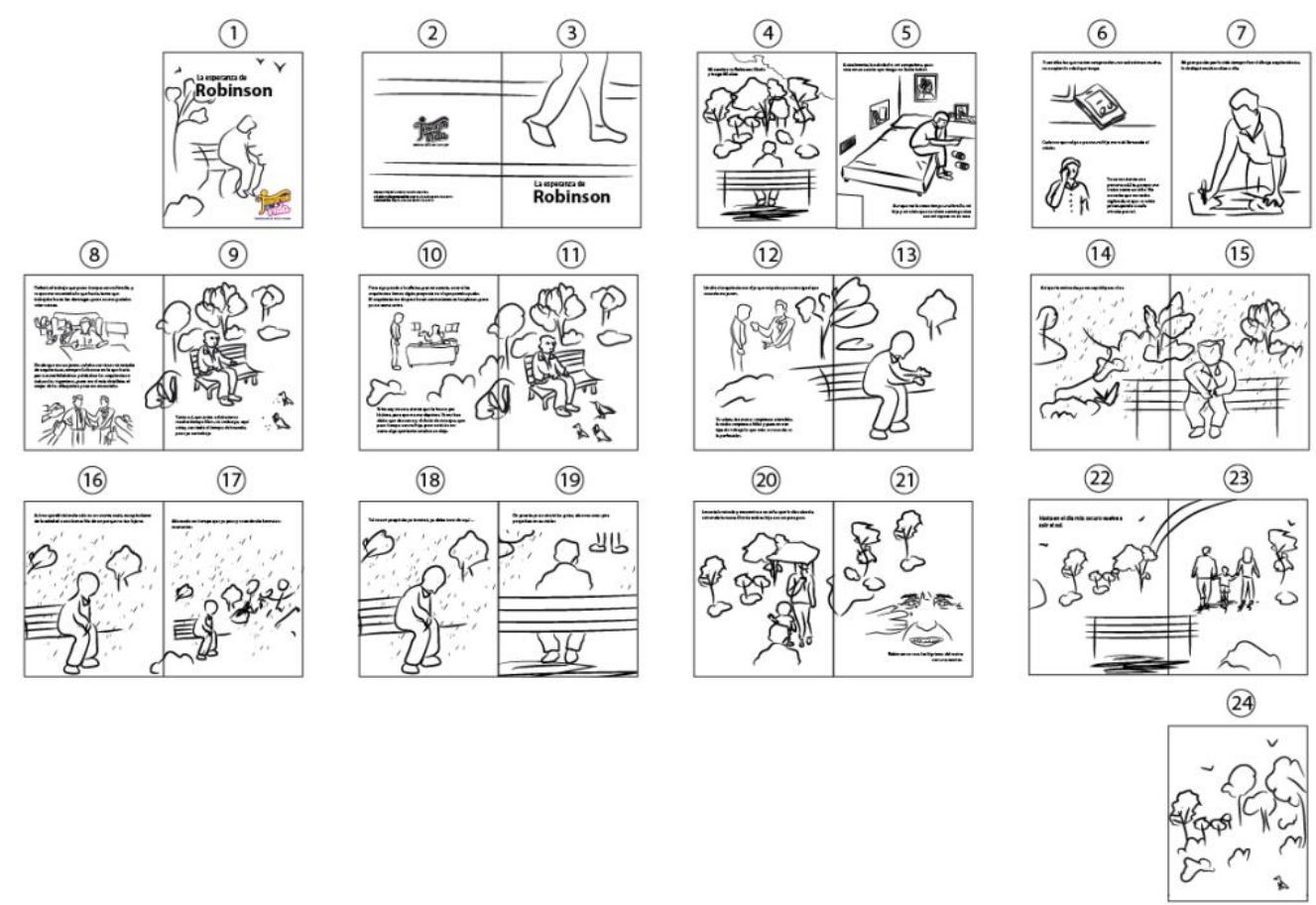

Figura 24. Machote del cuento. Elaboración propia. 

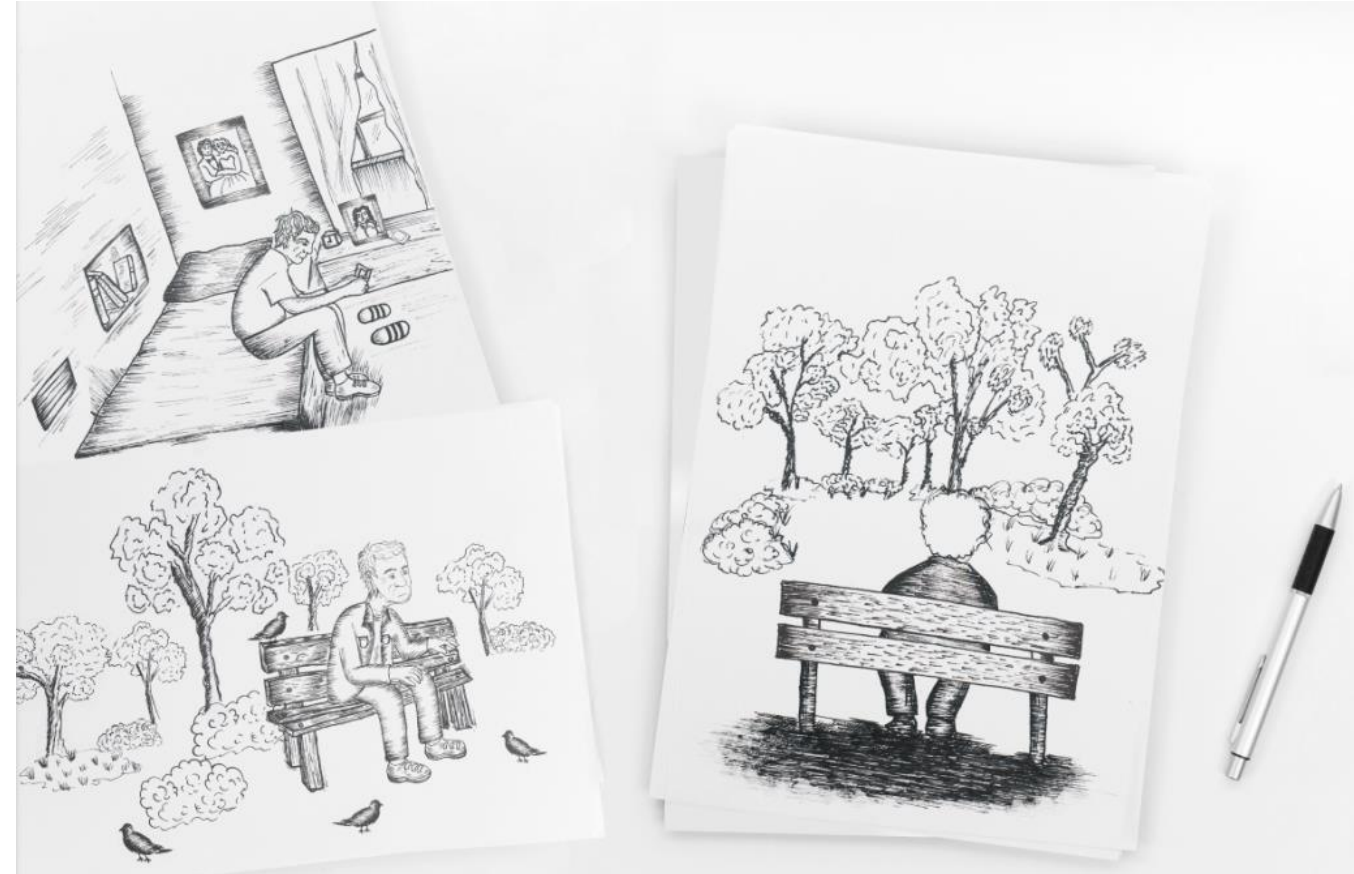

Figura 25. Ilustración a mano alzada. Elaboración propia.

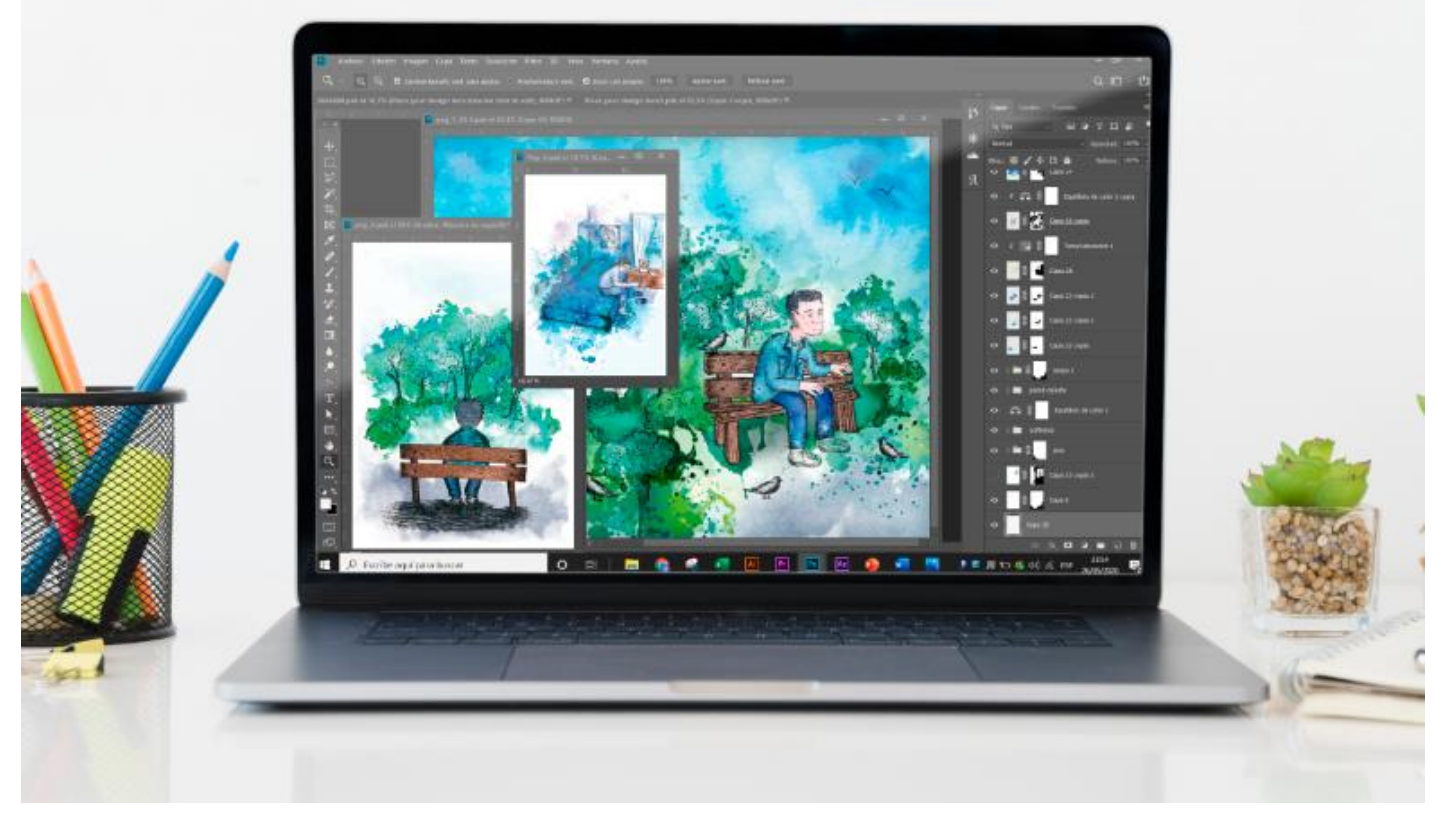

Figura 26. Colorización de las ilustraciones. Elaboración propia. 


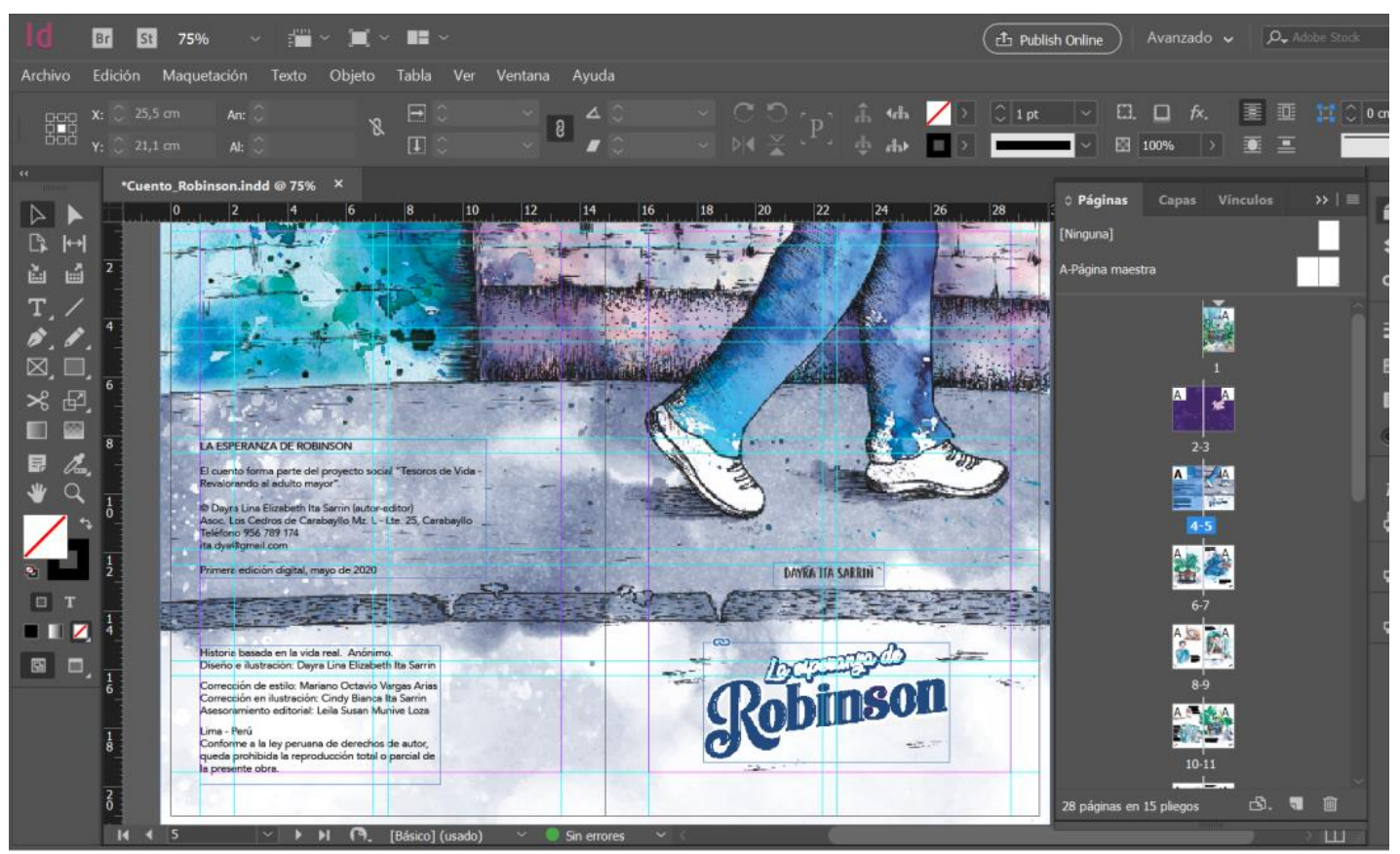

Figura 27. Diseño y diagramación del cuento. Elaboración propia.

\section{Segunda fase: Mini campaña de intriga.}

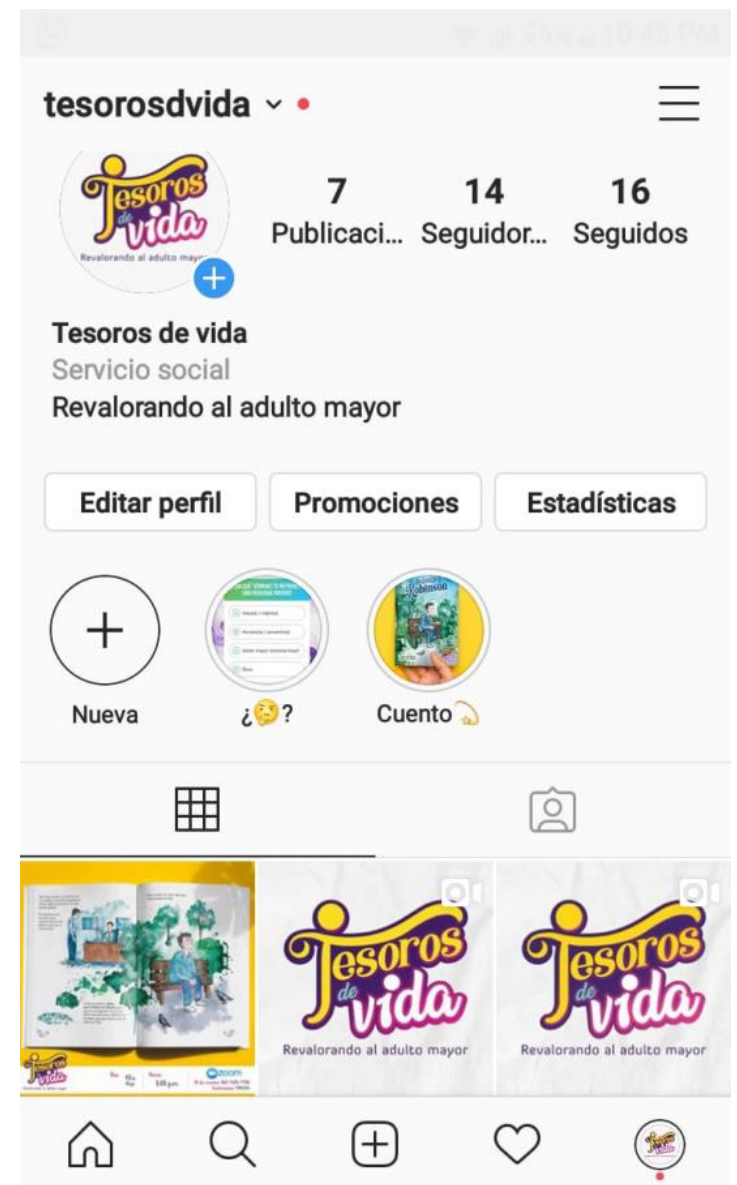

Figura 28. Instagram del proyecto. Elaboración propia. 

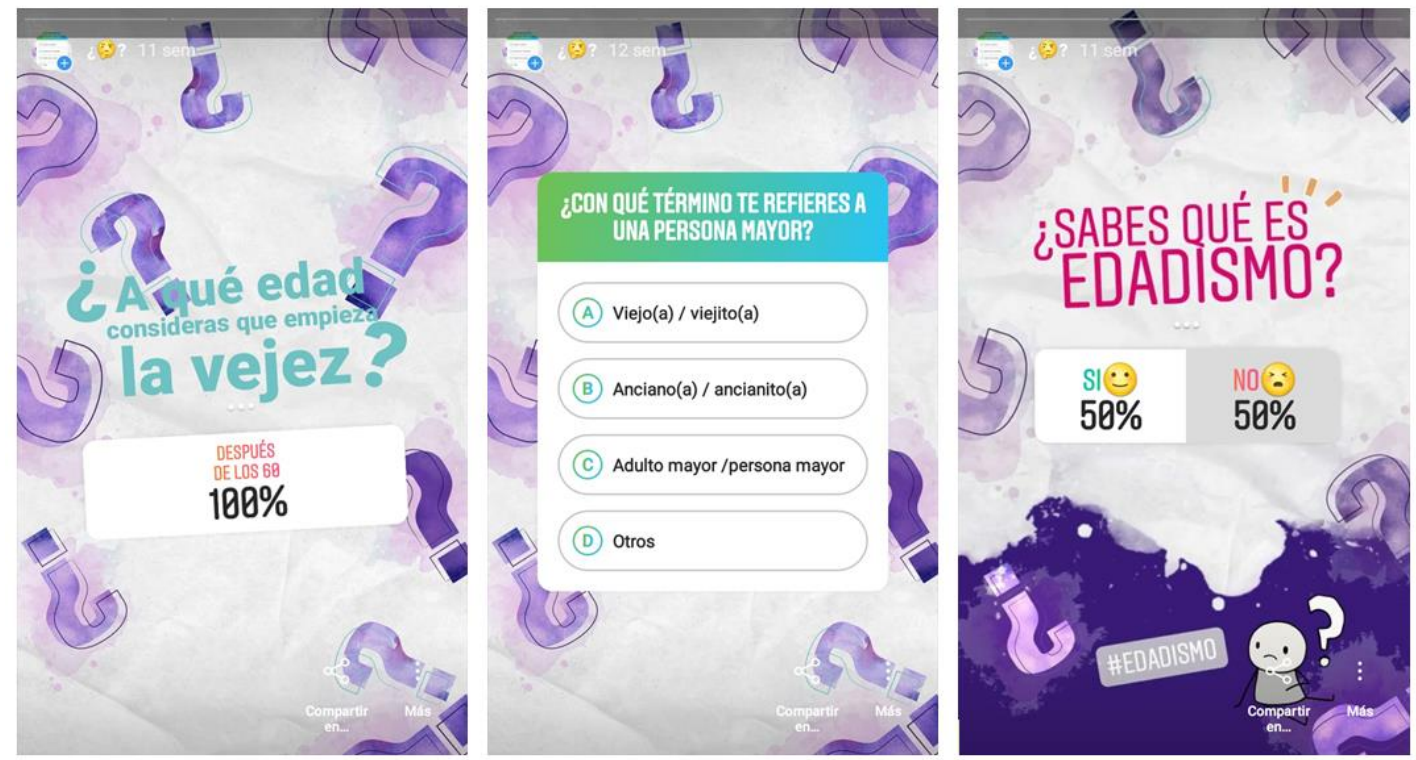

Figura 29. Historias publicadas en Instagram. Elaboración propia.

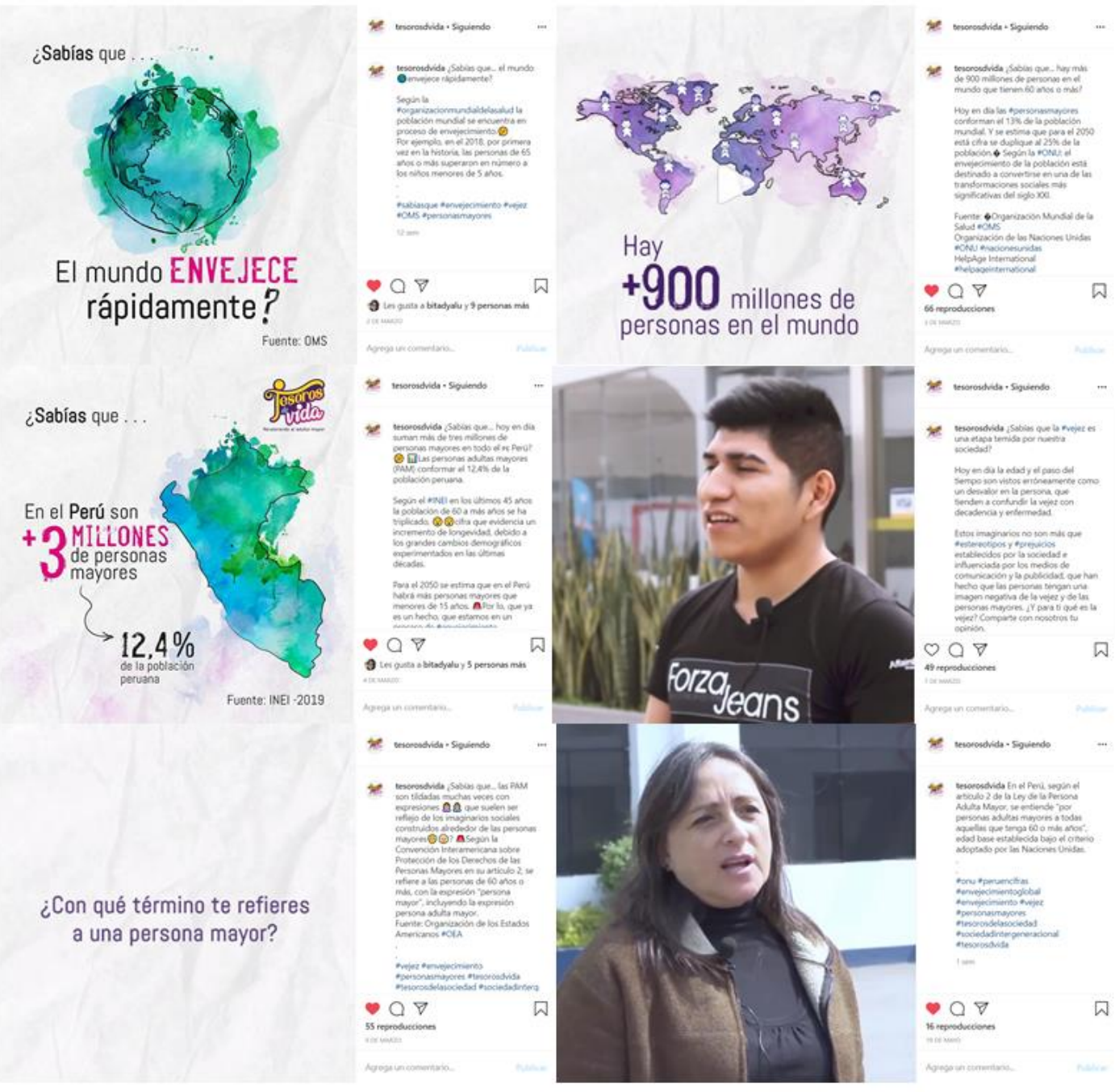

Figura 30. Post publicados en Instagram. Elaboración propia. 


\section{Tercera fase: Presentación del cuento.}

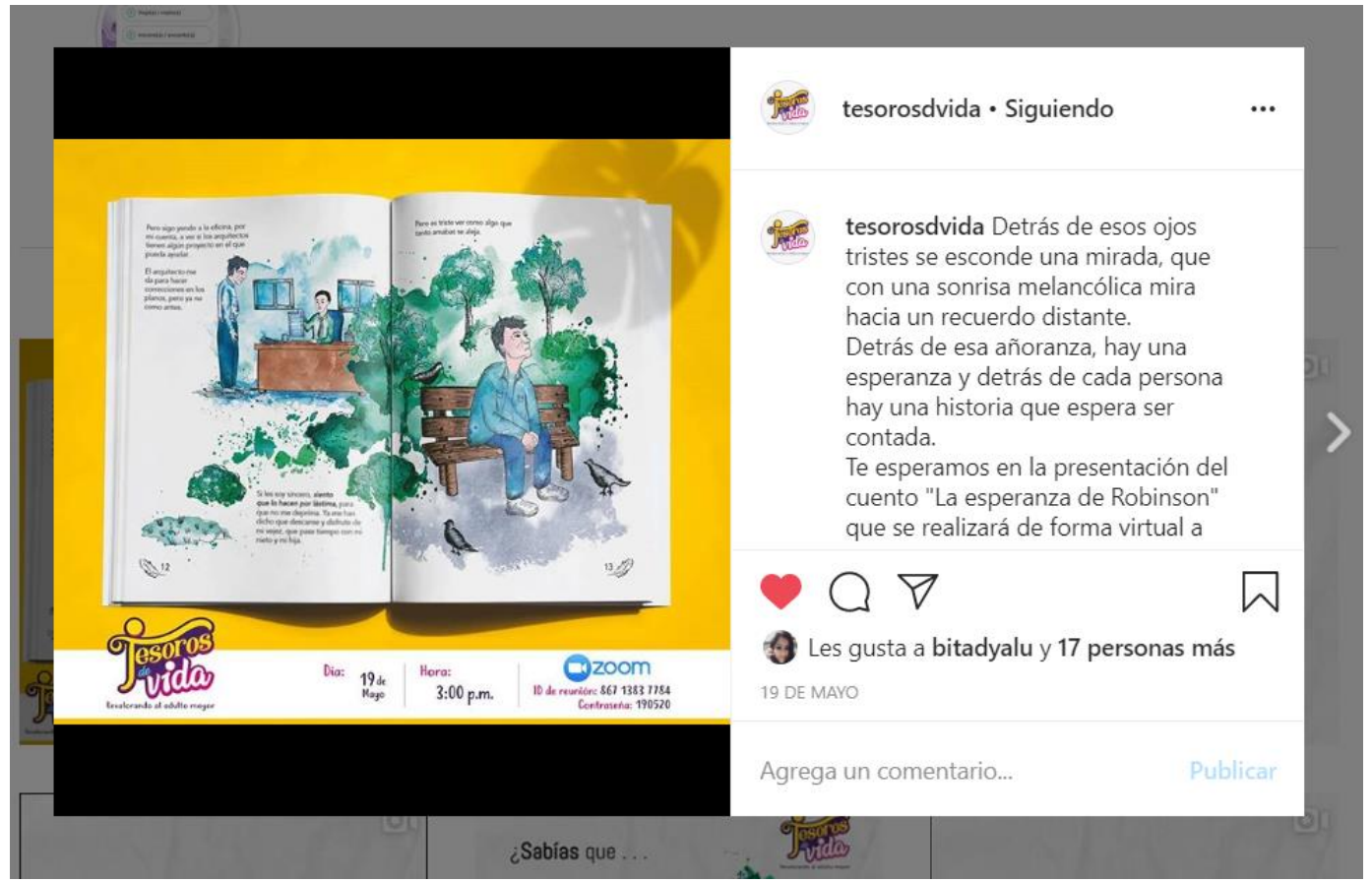

Figura 31. Publicación de la invitación por Instagram. Elaboración propia.
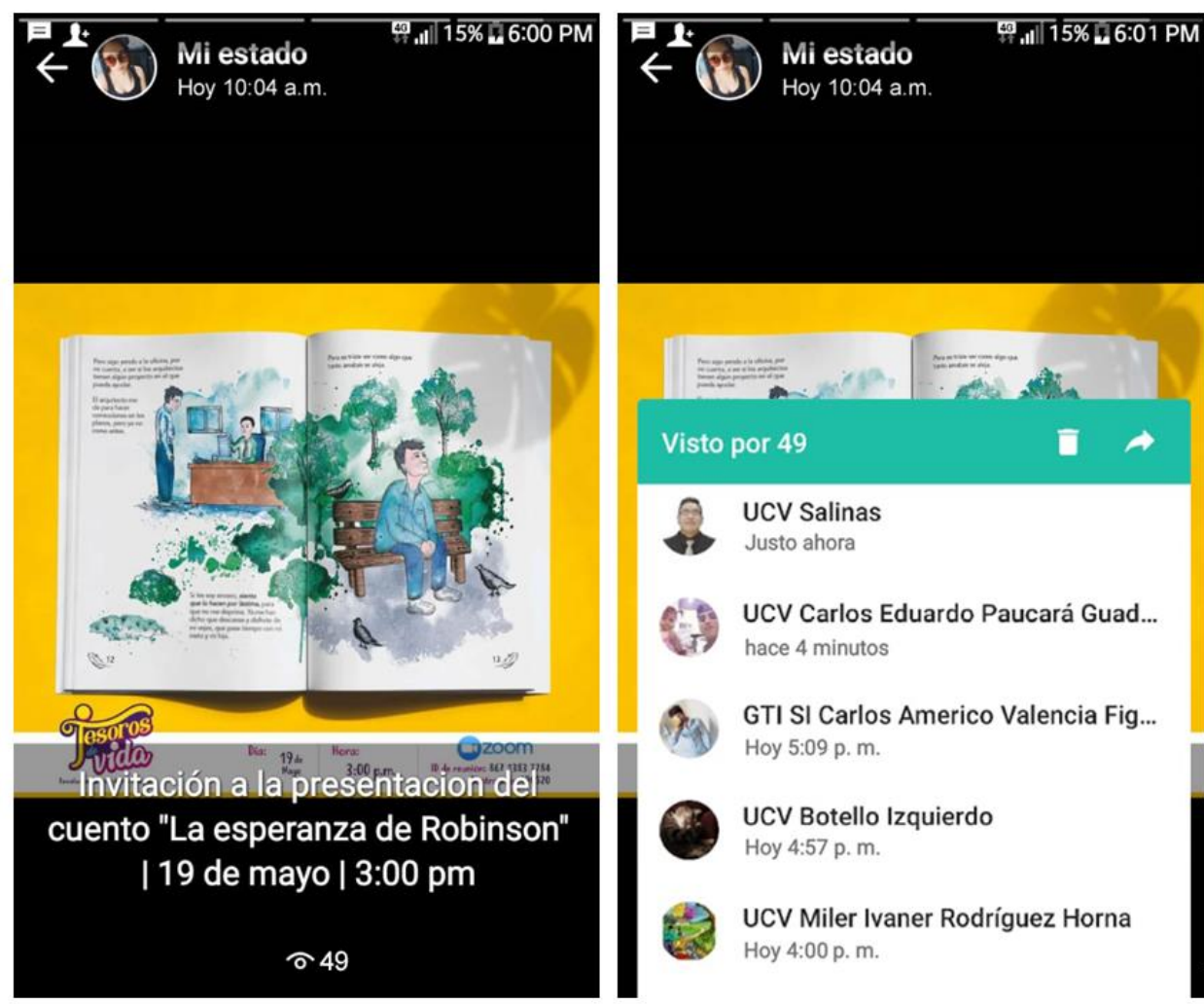

UCV Salinas

Justo ahora

UCV Carlos Eduardo Paucará Guad... hace 4 minutos

GTI SI Carlos Americo Valencia Fig... Hoy 5:09 p. m.

UCV Botello Izquierdo Hoy 4:57 p. m.

UCV Miler Ivaner Rodríguez Horna Hoy 4:00 p. m.

Figura 32. Publicación de la invitación por WhatsApp y número de vistos.

Elaboración propia. 


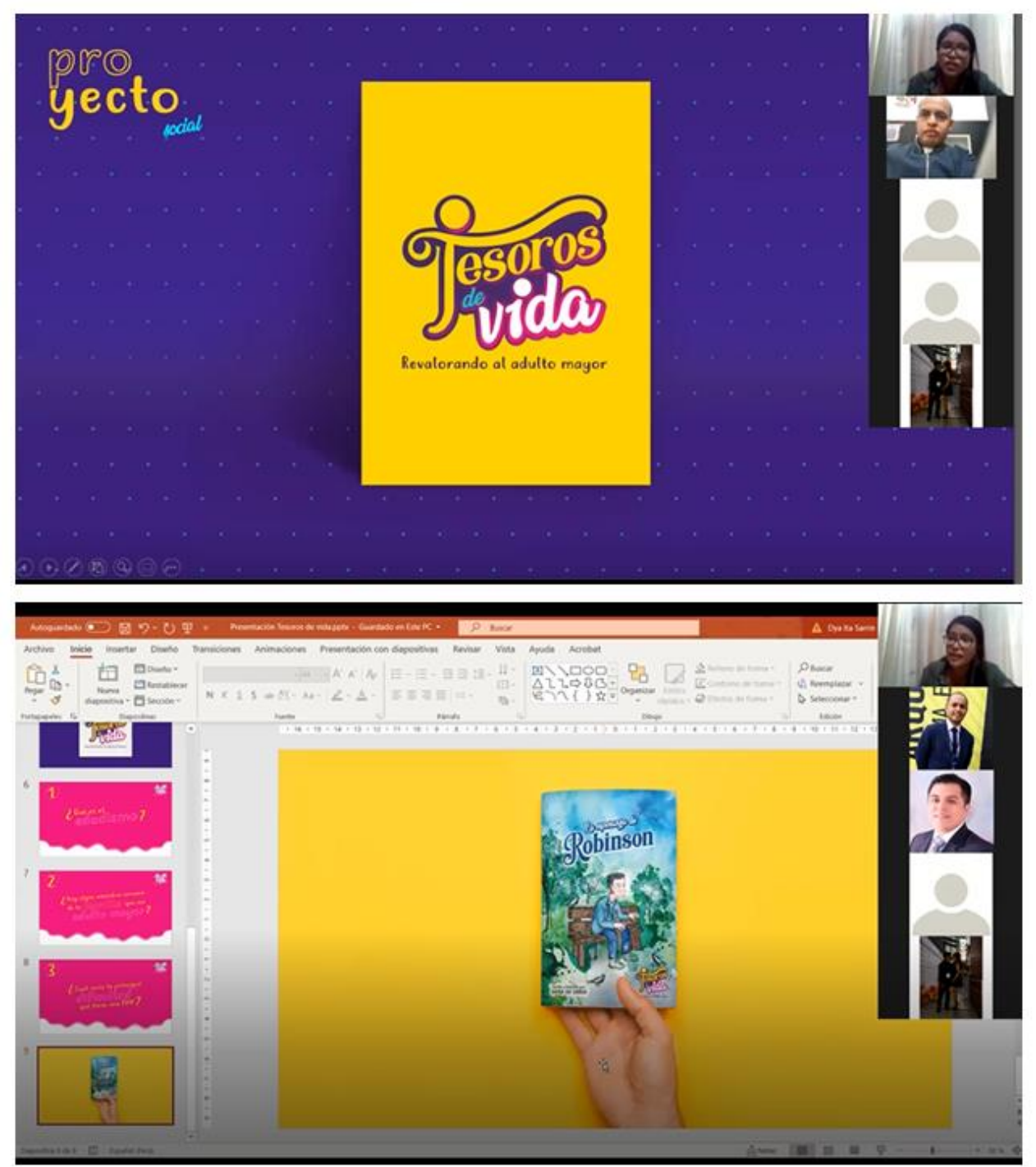

Figura 33. Presentación del proyecto social. Elaboración propia.

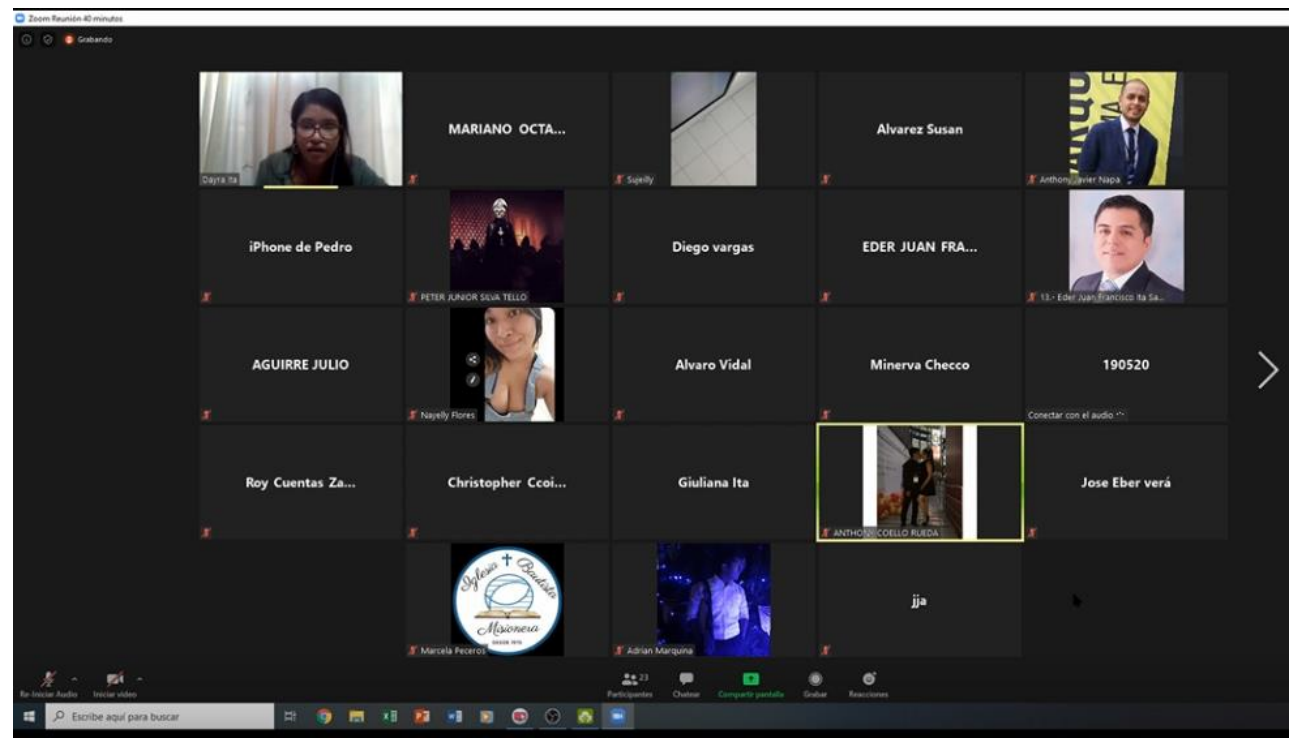

Figura 34. Participantes de la presentación virtual del cuento. Elaboración propia. 


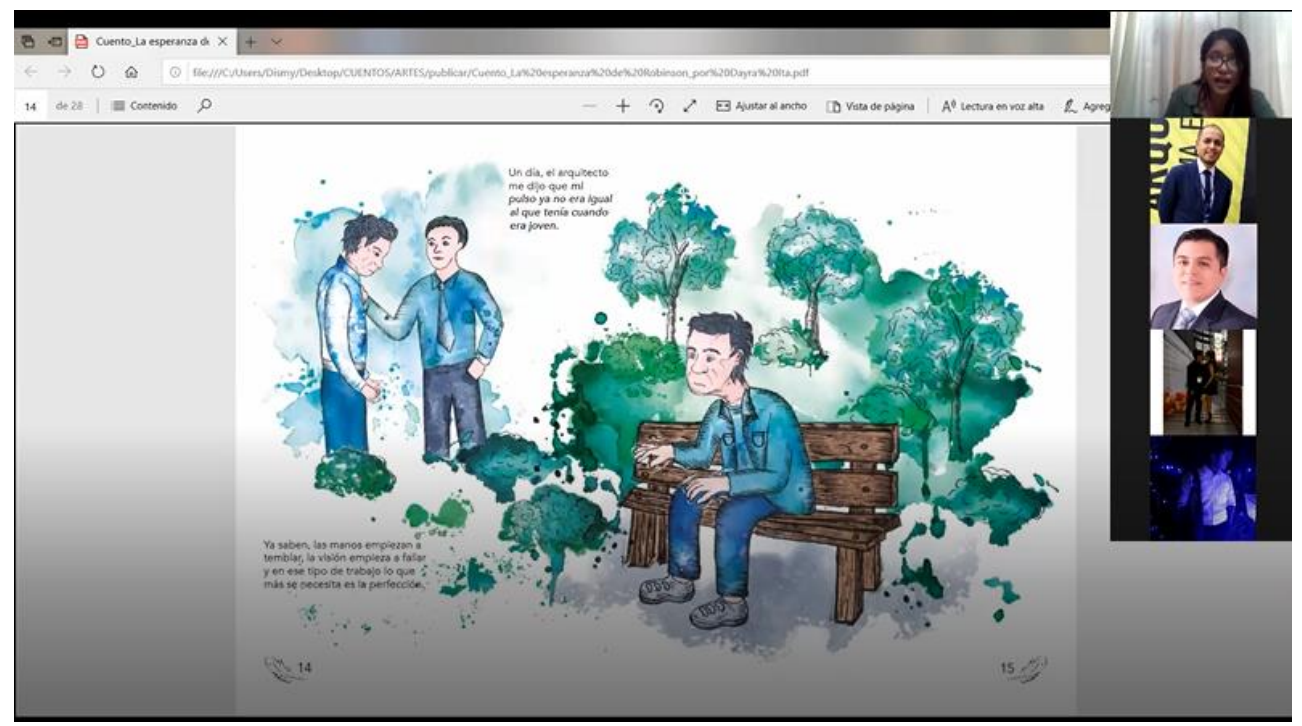

Figura 35. Lectura del cuento. Elaboración propia.

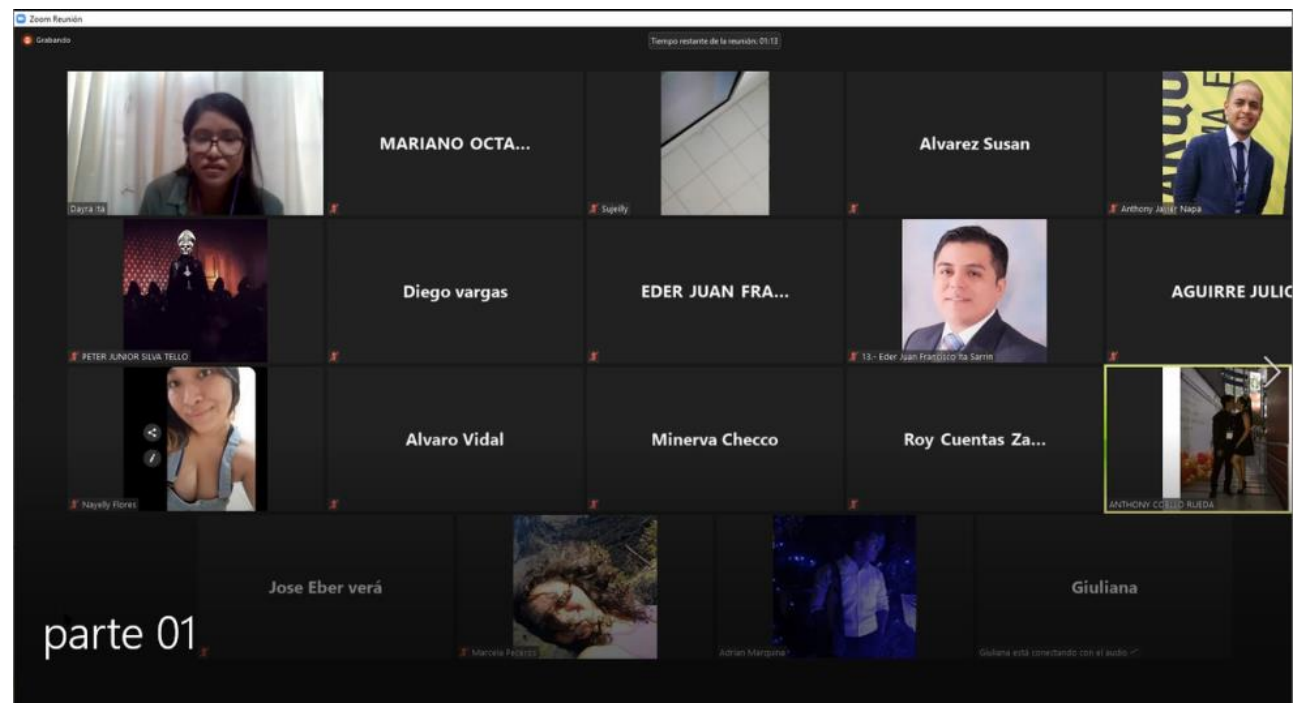

Figura 36. Comentarios de los participantes. Elaboración propia.

\section{Documentos que acreditan el proyecto}

A continuación, se expone los documentos que acrediten la evaluación de pares realizado por los Magisters Juan José Tanta Restreto y Osvaldo López Gaona. 


\section{CARTA DE PARES}

Lima, 23 de mayo de 2020

Señores,

Escuela de Posgrado

Universidad San Ignacio de Loyola

Por medio de la presente me dirijo a ustedes a fin de poder dar una opinión objetiva respecto al proyecto "Tesoros de Vida", diseñado por la Bachiller Dayra Lina Elizabeth Ita Sarrin. Esta obra está referida a promover la revaloración de la población adulta mayor a través de historias ilustradas de personas mayores, para ser reconocidos como el tesoro de la sociedad. De tal forma, el proyecto social permitirá contar las historias de vida de personas mayores por medio de ilustraciones que puedan ser transmitidas al público y así concientizar sobre la discriminación por edadismo. En consecuencia, redefinir el rol de las personas mayores en la sociedad, la comunidad y la familia, como personas que aportan conocimientos, experiencias y son transmisores de valores intergeneracionales. Todo ello, con el fin de revalorizar la experiencia, el esfuerzo y las habilidades de aquellos que poseen el conocimiento de toda una vida.

Por lo tanto, al analizar y revisar el proyecto minuciosamente encuentro que el mismo es pertinente debido a la escasa producción editorial en temas tan sensibles como es el caso de los adultos mayores y que ayuden a concientizar su importancia dentro de las familias, además de valorarlos como fuentes de experiencia y conocimiento dentro de la sociedad. Con este proyecto podemos evidenciar como a partir del diseño, se puede comenzar a construir soluciones a problemas sociales latentes.

Atentamente,

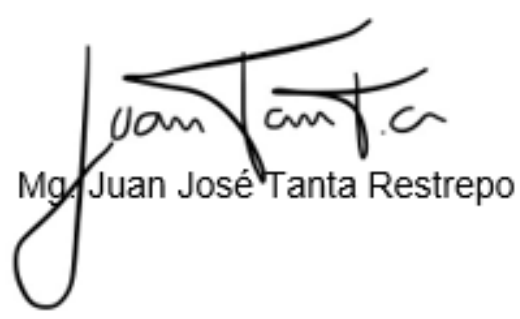

Figura 37. Carta de evaluación de pares $\mathrm{N}^{\circ} 1$. Elaboración propia. 


\section{CARTA DE PARES}

Puebla, México, 29 de Mayo de 2020

Señores,

Escuela de Posgrado

Universidad San Ignacio de Loyola

Por medio de la presente me dirijo a ustedes a fin de poder dar una opinión objetiva respecto al proyecto "Tesoros de Vida", diseñado por la Bachiller Dayra Lina Elizabeth Ita Sarrin. Esta obra está referida a promover la revaloración de la población adulta mayor a través de historias ilustradas de personas mayores, para ser reconocidos como el tesoro de la sociedad. De tal forma, el proyecto social permitirá contar las historias de vida de personas mayores por medio de ilustraciones que puedan ser transmitidas al público y así concientizar sobre la discriminación por edadismo. En consecuencia, redefinir el rol de las personas mayores en la sociedad, la comunidad y la familia, como personas que aportan conocimientos, experiencias y son transmisores de valores intergeneracionales. Todo ello, con el fin de revalorizar la experiencia, el esfuerzo y las habilidades de aquellos que poseen el conocimiento de toda una vida.

Por lo tanto, al analizar y revisar el proyecto minuciosamente encuentro que el mismo es destacable en el sentido de que cumple satisfactoriamente con el objetivo que se ha propuesto: que desde la perspectiva gráfica y las oportunidades que ofrece la ilustración, el proyecto consigue evidenciar a manera de cuento, el problema latente de la discriminación por edadismo y más aún, a través del mensaje, la construcción del texto, la generación de las imágenes y la síntesis que logra en ellas se hace presente no solo la parte narrativa o anecdótica de la historia, sino que se involucra en la parte simbólica y perceptual tocando elementos sensitivos y sensoriales, que hacen evocar partes emotivas en el espectador quien lee el producto editorial elaborado. Las imágenes son contundentes, hay un buen manejo del dibujo y la ilustración y la fuerza que le otorgan los colores en una paleta sobria hace que el concepto de adultez, frialdad y abandono se hagan presentes y evidencien más el problema del abandono, la depresión y la discriminación. Creo firmemente que el trabajo de investigación desarrolla un ambiente notable de un problema que hoy día se está viviendo y establece una línea real de lo que desafortunadamente, pero de manera atinada menciona la frase célebre: "como te ves me vi, como me ves te verás ${ }^{n}$, y como desarrollo investigativo plantea fielmente su objetivo, mismo que la autora al presentarse la contingencia provocada por el COVID- 19 no se amilanó y continuó desarrollando para obtener la información que requería. Respecto de la parte gráfica, el proyecto de solución cumple con lo requerido en términos de diseño, se hacen presentes los criterios de 10 creativo -existe idea, hay novedad, hay notabilidad y contribuye a la búsqueda de una solución-, 10 
comunicativo -existe simplicidad y funcionalidad efectiva del mensaje emitido, mismo que sin necesitar interlocución, genera un acercamiento emotivo a la historia escrita y gráfica, despierta conciencia -, y 10 perceptivo -existe una buena organicidad de los elementos que construyen tanto el diseño editorial, textos e imágenes, como en la composición y estructura de los elementos ilustrados, así como un buen manejo del color, la tipografía y por tanto de la imagen.

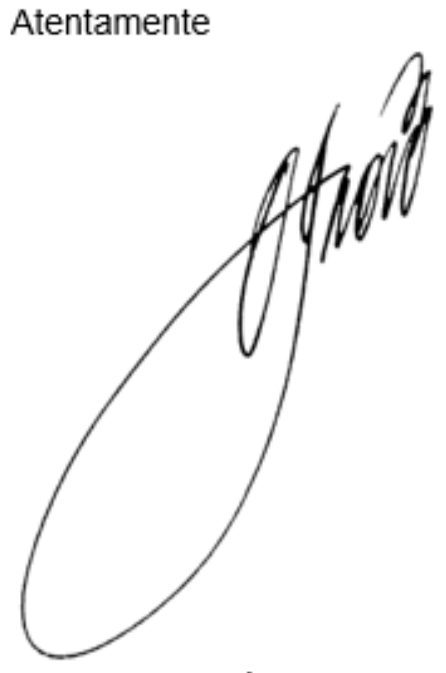

Mg. Osvaldo López Gaona

Figura 38. Carta de evaluación de pares $\mathrm{N}^{\circ}$ 2. Elaboración propia. 


\section{Conclusiones}

De acuerdo con lo analizado en la investigación y el desarrollo del proyecto se concluye lo siguiente:

- Después del estudio realizado se puede evidenciar que existen ciertas actitudes discriminatorias por edadismo que influyen en el desarrollo social de las personas mayores. Empezando desde un ámbito familiar, que afecta por igual a todos los miembros de la comunidad.

- Pese a ello, existe un gran desconocimiento referente a la discriminación por edadismo por parte de los jóvenes, que tienen una imagen negativa de la vejez, basado en prejuicios y estereotipos que acaban transformándose en una actitud habitual.

- Desde una perspectiva gráfica, la ilustración evidencia el problema de la discriminación por edadismo. Reforzado por una paleta sobria que refuerza la frialdad, el abandono, la depresión y discriminación que sufre el personaje.

- El mensaje, la construcción de textos, la generación de imágenes y síntesis, no solo se hace presente en la parte narrativa de la historia, sino que implica una parte simbólica y perceptual tocando elementos sensitivos y sensoriales, que evocan emociones al lector.

- La pieza gráfica, no solo refleja la historia de un adulto mayor, sino que permite transmitir, los sentimientos y pensamientos que tiene esta persona al ser discriminado por parte de personas allegadas a él. De ahí concluimos, la importancia de concientizar en los jóvenes este tipo de discriminación.

- La presentación de la pieza gráfica cumplió con los objetivos planteados, previamente, en el proyecto, pues logró que los participantes, en la presentación, reconozcan el rol que cumplen las personas adultas mayores, reconociéndolos 
como transmisores de experiencias, conocimientos y valores intergeneracionales.

Logrando así revalorar la experiencia, el esfuerzo y las habilidades de aquellos que poseen el conocimiento acumulado durante toda su vida.

- En el proyecto "Tesoros de vida" se puede evidenciar como a partir del diseño gráfico, se puede lograr y fomentar soluciones a problemáticas latentes en la sociedad. Es por lo que, como diseñadora y agente de cambio, se logró contribuir en la mejora y construcción de una sociedad para todas las personas de distintas edades. 


\section{Recomendaciones}

Según lo observado a lo largo del proyecto, se sugiere implementar las siguientes recomendaciones:

- Debido a que en la actualidad es de suma importancia abordar el problema de la discriminación por edadismo, se recomienda seguir recopilando historias de vida y generando publicaciones que sean adaptadas a cuentos que narren las experiencias de más personas mayores. Logrando una colección de experiencias enfocadas a la revalorización y consideración de estas personas.

- Como recomendación para mejorar la difusión en redes, se aconseja contratar a un Community Manager que se encargue de gestionar los distintos canales digitales, lo cual, permitirá obtener una mayor continuidad y presencia en redes sociales mejorando la imagen, constancia y conexión con el proyecto.

- Para reforzar el proyecto se recomienda que la pieza editorial diseñada, no solo esté en formato digital, sino incluir un soporte físico. Debido a que el formato preferido para la mayoría de las personas continúa siendo, a pesar de todo, el papel. 


\section{Referencias Bibliográficas}

Artediez (2019, 16 de octubre). "Miedos y otros Monstruos" por Aida Valugo Ramírez [Artediez.es] Recuperado de https://artediez.es/blog/proyectos/miedos-y-otrosmonstruos-por-aida-valugo-ramirez/

Blouin,C., Tirado, E. y Mamani, F. (2018). La situación de la población adulta mayor en el Perú: Camino a una nueva política. Recuperado de http://cdn01.pucp.education/idehpucp/wpcontent/uploads/2018/11/23160106/publicacion-virtual-pam.pdf

Castellano, C. y De Miguel, A. (2010). Estereotipos viejistas en ancianos: actualización de la estructura factorial y propiedades psicométricas de dos cuestionarios pioneros. Recuperado de https://www.ijpsy.com/volumen10/num2/261/estereotipos-viejistasen-ancianos-actualizaci-ES.pdf

Causse, M. (2009). El concepto de comunidad desde el punto de vista socio - históricocultural y lingüístico. Recuperado de https://www.redalyc.org/pdf/1813/181321553002.pdf

Comisión Nacional contra la Discriminación (CONACOD). (2019). Informe sobre la discriminación en medios de comunicación en el Perú, con especial énfasis en la discriminación étnico-racial. Recuperado de https://cdn.www.gob.pe/uploads/document/file/297520/Informe_CONACOD_Discri minaci\%C3\%B3n_Medios.pdf

Compañía Peruana de Estudios de Mercado y Opinión Pública (2019). Perú: Población 2019 (Recuperado de http://www.cpi.pe/images/upload/paginaweb/archivo/26/mr_poblacional_peru_20190 5.pdf 
Consejo Consultivo de Radio y Televisión. (2015). 2015 - Estudio sobre consumo radial y televisivo. Recuperado de http://www.concortv.gob.pe/wpcontent/uploads/2015/10/01-Total-nacional.pdf

Consejo Consultivo de Radio y Televisión. (2015). Análisis comparativo de los principales noticieros de televisión en señal abierta de la ciudad de Lima - 2015. Recuperado de http://www.concortv.gob.pe/file/2015/infografia-noticieros.pdf

Consejo Consultivo de Radio y Televisión. (2017). Los Adultos Mayores en la TV peruana. Recuperado de http://www.concortv.gob.pe/noticias/los-adultos-mayores-en-la-tvperuana/de las Personas Mayores. Recuperado de https://fiapam.org/wpcontent/uploads/2013/06/abay-participacion-01.pdf

Cumpa, L. (2002). Fundamentos de diagramación: revistas. Recuperado de https://es.scribd.com/document/156607662/Cumpa-Gonzalez-Luis-AlbertoFundamentos-De-Diagramacion-Revistas-pdf

De Miguel, A. y Castellano, C. (2012). Evaluación del componente afectivo de las actitudes viejistas en ancianos: escala sobre el Prejuicio hacia la Vejez y el Envejecimiento (PREJ-ENV). Recuperado de https://dialnet.unirioja.es/descarga/articulo/3849718.pdf

Defensoría del pueblo. (2007). La discriminación en el Perú. Problemática, normatividad y tareas pendientes. Recuperado de http://alertacontraelracismo.pe/sites/default/files/Ladiscriminacio\%CC\%81n-en-el-Peru\%CC\%81-problema\%CC\%81tica-normatividady-tareaspendientes \%20\%28Harry\%20Colchado\%27s\%20conflicted\%20copy\%202017-0908\%29.pdf

Diaz, L. (2015, 31 de agosto). La imagen de las personas mayores en los medios de comunicación [Cuartaedad.com]. Recuperado de 
http://www.cuartaedad.com/articulos/la-imagen-de-las-personas-mayores-en-losmedios-de-comunicacion/

Diez, J. (2016, 03 de octubre). Hay que redefinir el rol del adulto mayor en la sociedad [puntoedu.pucp.edu.pe]. Recuperado de: https://puntoedu.pucp.edu.pe/entrevistas/hay-que-redefinir-el-rol-del-adulto-mayoren-la-sociedad/

Dulcey, E. (2015). Envejecimiento y vejez. Categorías y conceptos. Recuperado de https://es.scribd.com/read/305234535/Envejecimiento-y-vejez-Categorias-yconceptos\#

Eguaras, M. (2018, 09 de enero). Qué es el diseño editorial [marianaeguaras.com]. Recuperado de: https://marianaeguaras.com/que-es-el-disenoeditorial/\#: :text=\%22El\%20dise\%C3\%B1o\%20editorial\%20es\%20el,la\%20historia $\% 20(\% \mathrm{E} 2 \% 80 \% \mathrm{~A} 6) \% 22$.

Espinoza, P. (2015). La ilustración como herramienta de comunicación dentro de las artes visuales (Tesis de Licenciatura). Recuperado de https://es.scribd.com/doc/29139419/ILUSTRACION-EN-LA-COMUNICACIONGRAFICA-final

Espinoza, Y. (2018). Funcionamiento familiar prevalente en usuarios del centro del adulto mayor EsSalud, Huaraz 2018. Recuperado de: http://repositorio.uladech.edu.pe/bitstream/handle/123456789/5002/FUNCIONAMIE NTO_FAMILIAR_ADULTOS_MAYORES_ESPINOZA_MENA_HELEN_YARIM A.pdf? sequence $=1 \&$ isAllowed $=\mathrm{y}$

Estudio Mike (2019, 31 de agosto). ¿Qué es el diseño editorial?. Recuperado de https://www.mique.es/que-es-el-diseno-editorial/ 
Federación Iberoamericana de Asociaciones de Personas Adultas Mayores (2013). La soledad y el aislamiento social, enemigos de los adultos mayores. Recuperado de https://fiapam.org/la-soledad-y-el-aislamiento-social-enemigos-de-los-adultosmayores/

Fernández, A. (2012). El arte de la ilustración. Del concepto al éxito. Madrid, España: Amaya Multimedia.

Frascara, J. (2000). Diseño gráfico y comunicación (7ª Ed.) Buenos Aires, Argentina: Ediciones Infinito. Recuperado de https://catedragrafica1.files.wordpress.com/2009/09/diseno-y-comunicacion.pdf

Fundación Saldarriaga Concha (2013). Guía para periodistas. Vejez y envejecimiento. Recuperado de http://www.saldarriagaconcha.org/images/fsc/pdf/prensa/kit_medios/guia_periodistas _vejez.pdf

Gálvez, A \& Ponce, L. (2007). Centro de atención integral y aprendizaje intergeneracional para el adulto mayor (Tesis de Título). Recuperado de http://cybertesis.urp.edu.pe/bitstream/urp/1107/1/galvez_na-ponce_cl.pdf

García, M. (2019, 15 de agosto). 15 definiciones: ¿Qué es el diseño gráfico? | Citas de autores. [Paredro.com]. Recuperado de https://www.paredro.com/15-definicionesdiseno-grafico-citas-autores/

Géne, J., Ruiz, M., Obiols, N., Oliveras, L. \& Lagarda, E. (2016). Aislamiento social y soledad: ¿qué podemos hacer los equipos de atención primaria? Atención Primaria, 48, 604-609. Recuperado de https://reader.elsevier.com/reader/sd/pii/S0212656716301809?token=8C07B51B98F DACA2318273FEB0E39ED0DC73E6F2ED876E86D2E22703E7BA65DD3FE29D6 26B71B6184393DFF9893DF808 
Gutiérrez, E. (2013). Vivencias del adulto mayor internado en el asilo el Buen Jesús Arequipa 2013. Recuperado de http://repositorio.unsa.edu.pe/bitstream/handle/UNSA/2302/ENgumeer.pdf?sequence $=1 \&$ isAllowed $=\mathrm{y}$

Hernández, R., Fernández, C. \& Baptista, P. (2010). Metodología de la Investigación. (5. a ed.). México: Mc Graw-Hill.

Instituto Andaluz de la Mujer. (2006). Vivir los cuentos. Campaña del juego y el juguete no sexista, no violento. Recuperado de http://www.juntadeandalucia.es/iam/catalogo/doc/iam/2006/23243_cuaderno.pdf

Instituto de Mayores y Servicios Sociales [IMSERSO]. (2009). Edadismo en Estados Unidos. Recuperado de https://www.imserso.es/InterPresent2/groups/imserso/documents/binario/boletinopm4 $0 . p d f$

Instituto Nacional contra la Discriminación, la Xenofobia y el Racismo. (2017).

Discriminación por edad, vejez, estereotipos y prejuicios. Recuperado de http://www.inadi.gob.ar/contenidos-digitales/wpcontent/uploads/2017/06/Discriminacion-por-Edad-Vejez-Estereotipos-y-PrejuiciosFINAL.pdf

Instituto Nacional de Estadística e Informática. (2017). Perú: Perfil Sociodemográfico 2017. Recuperado de https://www.inei.gob.pe/media/MenuRecursivo/publicaciones_digitales/Est/Lib1539/c ap01.pdf

Instituto Nacional de Estadística e Informática. (2019). Informe Técnico Situación de la Población Adulta Mayor (Informe $N^{\circ}$ 2). Recuperado de https://www.inei.gob.pe/media/MenuRecursivo/boletines/adultomayorjunio.pdf 
Instituto Nacional de Estadística e Informática. (2019). Informe Técnico Situación de la Población Adulta Mayor (Informe $N^{\circ}$ 3). Recuperado de https://www.inei.gob.pe/media/MenuRecursivo/boletines/03-informe-tecnicon03_adulto-abr-may-jun2019.pdf

Lebrusán, I. (2019, 17 de marzo). ¿Por qué tenemos tantos prejuicios sobre la vejez? [cenie.eu]. Recuperado de: https://cenie.eu/es/blogs/envejecer-en-sociedad/por-quetenemos-tantos-prejuicios-sobre-la-vejez

Levy, B. y Banaji, M. (2004). "Viejismo Implícito" en Viejismo, Estereotipos y Prejuicios contra las Personas Mayores. Recuperado de https://envejecimientoysociedad.files.wordpress.com/2010/07/ageism.pdf

Ley No. 30490 sobre la Persona Adulta Mayor (2016). En Diario Oficial El Peruano 2. Perú

López, A. (2014). Curso Diseño Gráfico. Fundamentos y técnicas. Madrid, España: Anaya Multimedia, pp. 288

López, J. (2018). El cuento y su valor. Recuperado de https://books.google.com.pe/books?id=uMFiDwAAQBAJ\&printsec=frontcover\#v=on epage $\& \mathrm{q} \& \mathrm{f}=$ false

Lozada, A. (2004). Edadismo: consecuencias de los estereotipos, del prejuicio y la discriminación en la atención a las personas mayores. Algunas pautas para la intervención. (Informe $\mathrm{N}^{\circ}$ 14). Madrid: IMSERSO. Recuperado de http://www.imsersomayores.csic.es/documentos/documentos/losada-edadismo-01.pdf Martínez, M. (2012). Como trabajar el generador de cuentos (Orientacionandajuar.es). Recuperado de https://orientacionandujar.files.wordpress.com/2012/05/como-trabajarel-generador-de-cuentos.pdf 
Martínez, M., Vivaldo, M. \& Mendoza, V. (s.d.). ¿Qué es el viejismo?. Recuperado de: http://inger.gob.mx/pluginfile.php/1682/mod_resource/content/10/Repositorio_Cursos /Archivos/Promocion/Unidad_I/PSM_Lectura_Que_es_el_viejismo_060118.pdf

Mesa de Concertación para la Lucha contra la Pobreza. (2018). Envejecimiento con Dignidad: Una mirada a los derechos de las personas adultas mayores en el Perú. Recuperado de https://www.mesadeconcertacion.org.pe/sites/default/files/archivos/2018/documentos/ 07/libro_envejecimiento_con_dignidad_baja.pdf

Molina, P y Muñoz, D. (2015). Diagnóstico diferencial: deterioro de la interacción social y aislamiento social. Recuperado de http://www.revistareduca.es/index.php/reducaenfermeria/article/download/1875/1883

Navarro, O. (2017). Aislamiento social del adulto mayor Hospital Nacional Arzobispo Loayza Lima 2016 (Tesis de licenciatura). Recuperado de http://repositorio.ucv.edu.pe/bitstream/handle/UCV/5990/Navarro_SO.pdf?sequence= $1 \&$ isAllowed=y

Neoattack. (2019). Diseño editorial [neoattack.com]. Recuperado de: https://neoattack.com/neowiki/diseno-editorial/

Organización de los Estados Americanos. (n.d.). Convención interamericana sobre la protección de los derechos humanos de las personas mayores (a-70). Recuperado de http://www.oas.org/es/sla/ddi/tratados_multilaterales_interamericanos_a70_derechos_humanos_personas_mayores.asp

Ortega, G. (2007). Mi barrio un mensaje ilustrado: sistema de comunicación visual sobre soportes impresos para adolescentes, basado en la identificación (Tesis de titulación). Recuperado de http://repositorio.uchile.cl/tesis/uchile/2007/ortega_g/sources/ortega_g.pdf 
Puetate, S. (2014). Diseño de un texto didáctico ilustrado sobre mitos y leyendas tradicionales en la ciudad de Otavalo, para estudiantes de nivel escolar (Tesis de titulación). Recuperado de http://repositorio.uisrael.edu.ec/bitstream/47000/1103/1/UISRAEL\%20-\%20ECDIS\%20-\%20378.242\%20-\%2085.pdf

Ramos, J., Meza, A., Maldonado, I. Ortega, M. y Hernández, M. (2009). Aportes para una conceptualización de la vejez. Recuperado de http://www.cucs.udg.mx/revistas/edu_desarrollo/anteriores/11/011_Ramos.pdf

Real Academia Española. (2001). Diccionario de la lengua española (23. ${ }^{\text {a }}$ ed.). Consultado en https://dle.rae.es/?id=bSrxBGn

Real Academia Española. (2001). Diccionario de la lengua española (23. a ed.). Consultado en https://dle.rae.es/?id=DtDzVTs

Rodríguez, S. (1989). La vejez: historia y actualidad. Recuperado de https://books.google.com.pe/books?id=6SWOOwNgdg0C\&pg=PA33\&dq=la+geronto $\log \% \mathrm{C} 3 \% \mathrm{ADa} \& \mathrm{hl}=\mathrm{es}-$

419\&sa=X\&ved=0ahUKEwiAyL6B9JDkAhVEiFkKHZlxBsEQ6AEIMjAC\#v=onepa ge \&q=la $\% 20$ gerontolog $\% \mathrm{C} 3 \% \mathrm{ADa} \& \mathrm{f}=$ false

Saez, N., Meléndez, J. y Aleixandre, M. (1994). Los estereotipos en los ancianos: un estudio empírico y sus resultados. Recuperado de https://www.uv.es/ melendez/envejecimiento/esterotipos\%20ancianos.pdf

Sánchez, J. y López, E. (2012). Pensando en diseño gráfico. Recuperado de https://books.google.com.pe/books?id=McJNAQAAQBAJ\&printsec=frontcover\#v=o nepage $\& q \& \mathrm{f}=$ false 
Sánchez, O. (s.f.). Disección en vida de la ilustración. Cuestionamiento sobre lo visible y lo imaginable. Recuperado de https://es.scribd.com/document/233149150/Diseccion-enVida-de-La-Ilustracion

Sanmiguel, D. y Canal, F. (2013). Todo sobre la técnica de la ilustración (2a ed.). Badalona, España: ParramónPaidotribo

Sanmiguel, D. y Ubach, T. (2014). Técnicas de ilustración (2a ed.). Badalona, España: ParramónPaidotribo

Santa, M. (n.d.). Interdisciplinariedad en el diseño. Metodología para innovar sobre procesos y resultados dentro de la educación formal. Recuperado de http://www.infolio.es/06infolio/metodo/miriamtello.pdf

Setenta y más (2012). Los mitos y estereotipos asociados a la vejez. N 314, pp. 46-51.

Recuperado de http://www.revista60ymas.es/InterPresent2/groups/revistas/documents/binario/s314inf orme.pdf

Tabuenca, E. (2019, 16 de mayo). Características del cuento: popular y literario (Unprofesor.com). Recuperado de https://www.unprofesor.com/lenguaespanola/caracteristicas-del-cuento-popular-y-literario-3356.html

Tückler, G. (1998). Literatura Para Niños Preescolares. Recuperado de h https://books.google.com.pe/books?id=L6kVg1atwmIC\&pg=PA161\&dq=elementos+ del+cuento\&hl=es419\&sa=X\&ved=0ahUKEwjZrZLfz_LmAhWOIbkGHWk1CfEQ6AEIQTAD\#v=one page $\& \mathrm{q}=$ elementos $\% 20 \mathrm{del} \% 20$ cuento $\& \mathrm{f}=$ false

Wong, W. (1991). Fundamentos del diseño bi y tri dimensional ( $7^{\mathrm{a}}$ ed.). Recuperado de https://centroculturalhaedo.edu.ar/cch/actualizacion_permanente/Fundamentos\%20del $\%$ 20Diseno\%20Bidimensional\%20y\%20tridimensional,\%20Wucius\%20Wong.pdf 
Zanón, D. (2007). Introducción al diseño editorial. Recuperado de https://books.google.es/books?hl=es\&lr=\&id=-UKgjnolasC\&oi=fnd\&pg=PA15\&dq=dise $\% \mathrm{C} 3 \% \mathrm{~B} 1 \mathrm{o}+\mathrm{editorial}+$ definici $\% \mathrm{C} 3 \% \mathrm{~B} 3 \mathrm{n} \&$ ots $=\mathrm{r}$ Qd1brH9gf\&sig=FwsOVIw7zrhaMQch4qfb7mebOE\#v=onepage $\& \mathrm{q}=$ dise $\% \mathrm{C} 3 \% \mathrm{~B} 1 \mathrm{o} \% 20$ editorial $\% 20$ definici $\% \mathrm{C} 3 \% \mathrm{~B} 3 \mathrm{n} \& \mathrm{f}=$ false 
Anexos

Anexo 1. Cuestionario realizado a la comunidad

\section{ENCUESTA}

El sipuiente cuestionario pretende conocer la percepción que tiene respecto a la imagen de la vejez y de la persona adula mayor. A continuación marque una sola opción.

*Obligatorid

Edad *

Tu respuesta

Género *

Elige

1. ¿Con qué término se refiere usted a una «persona adulta mayors?*

Elige

2. ¿A qué edad cree usted que alguien puede ser considerado persona adulta mayor? *

Elige

3. Para usted las personas mayores son... *

Elige

4. Considera que las personas mayores son... *

Elige

5. Según su percepción las personas mayores son... *

Elige

6. ¿Qué tan productivos son las personas mayores? *

Elige 
7. ¿Qué tan sabias considera usted a las personas mayores? * Elige

8. ¿Qué tan hábiles son las personas mayores? *

Elige

9. ¿Qué tan capaz son las personas mayores de adaptarse a los cambios? *

Elige

10. Para usted, ¿qué tan activos sexualmente son las personas mayores? *

Elige

11. ¿Qué tan sociables son las personas mayores? * Elige

12. Para usted, ¿la sociedad integra a las personas mayores? * Elige

13. Según su percepción las personas mayores son... *

Elige

14. ¿Cree usted que las personas mayores son valoradas? * Elige

\section{ENMIAR}

Nunca envies contraseriss a traves de Formularios de Google.

Este contenido no ha sido creado ni aprobsdo por Googe Naticar usp inadecuada- Condiciones del servico. olitica de privacidsd

\section{Google Formularios}


Anexo 2. Lista de preguntas de la entrevista realizada a las PAM

\begin{tabular}{|c|c|c|}
\hline UST, & $\begin{array}{c}\text { ENTREVISTA A LA PERSONA MAYOR } \\
\text { RESPECTO A LA IMAGEN DE LA VEJEZ Y DE LA } \\
\text { PERSONA MAYOR } \\
\text { dentoúcio }\end{array}$ & $\begin{array}{c}\text { Maestría en } \\
\text { Diseño Gráfico }\end{array}$ \\
\hline
\end{tabular}

Fecha:

Hora:

Entrevistador:

Datos del entrevistado

Nombre:

Edad:

Género: $\quad \square \mathrm{M} \square \mathrm{F}$

La siguiente entrevista pretende conocer la apreciación del adulto mayor respecto a la experiencia vivida, de tal manera se pueda complementar la información recopilada, en las encuestas realizadas.

\section{Lista de Preguntas}

1. Dime tu nombre, edad, profesión u oficio.

2. ¿Sientes que a veces te tratan como a un niño pequeño?

3. ¿Qué es lo que más echas de menos de tu juventud?

4. ¿Qué es lo mejor que se ha inventado desde que naciste?

5. ¿Tienes familia?

6. ¿Con qué personas vives actualmente?

7. ¿Qué cosas dejan de preocuparte cuando te haces mayor?

8. ¿Ha dejado de hacer algo que antes hacías?

9. ¿Qué haces con tanto tiempo libre?

10. ¿Te sientes útil?

11. ¿Tienes algún sueño por cumplir?

12. ¿Te sientes solo?

13. ¿En algún momento te has sentido discriminado por ser mayor?

14. ¿Pertenece a algún club, grupo o casa para adulto mayor? 
Anexo 3. Lista de preguntas de la entrevista a la comunidad

\begin{tabular}{|c|c|c|}
\hline 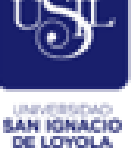 & $\begin{array}{c}\text { ENTREVISTA A LA COMUNIDAD } \\
\text { CON LA FINALIDAD DE CONOCER LA OPINIÓN DE LAS } \\
\text { PERSONAS SOBRE LA VEJEZ }\end{array}$ & $\begin{array}{l}\text { Maestria en } \\
\text { Diseño Gráfico }\end{array}$ \\
\hline
\end{tabular}

Fecha:

Hora:

Edad:

Género:
Entrevistador:

$\square \mathrm{M} \square \mathrm{F}$

La siguiente entrevista pretende conocer la percepción de las personas de la comunidad respecto a la imagen de la vejez, de tal manera se pueda complementar la información recopilada, en las encuestas realizadas.

\section{Lista de Preguntas}

1. Para ti, ¿̇qué es la vejez?

2. ¿Con qué término se refiere a una persona mayor?

3. ¿A qué edad considera usted que empieza la vejez?

4. ¿Cómo se ve usted de mayor? 
Anexo 4. Expresiones que se relaciona con las personas mayores.

\begin{tabular}{|c|c|}
\hline $\begin{array}{c}\text { Expresión correcta y/o } \\
\text { condicionada }\end{array}$ & $\begin{array}{c}\text { Expresión incorrecta o } \\
\text { condicionada }\end{array}$ \\
\hline Mayores, personas mayores: & Vejete, decrépito. Cucho (a) \\
\hline $\begin{array}{l}\text { Son términos objetivos, que no } \\
\text { conllevan carga ni valoraciones de } \\
\text { ningún tipo. }\end{array}$ & $\begin{array}{l}\text { Son términos peyorativos y } \\
\text { cargados de prejuicios, que no } \\
\text { responden a la realidad de la } \\
\text { mayoría de los y las mayores. }\end{array}$ \\
\hline \multirow{3}{*}{$\begin{array}{l}\text { Personas de edad avanzada, } \\
\text { Población mayor: } \\
\text { Es también una expresión adecuada } \\
\text { y neutral. }\end{array}$} & Abuelo (a) \\
\hline & Es un término insuficiente, que no \\
\hline & $\begin{array}{l}\text { representa a todas las personas } \\
\text { mayores, sino sólo a quienes tienen } \\
\text { esta relación de parentesco. Puede } \\
\text { tener además connotaciones } \\
\text { paternalistas. }\end{array}$ \\
\hline Anciano, Viejo (a) & Pensionados/as: \\
\hline $\begin{array}{l}\text { Su uso es relativo y está } \\
\text { condicionado al contexto en el que } \\
\text { se encuentra. }\end{array}$ & $\begin{array}{l}\text { Es un término adecuado pero } \\
\text { insuficiente, pues abarca sólo a } \\
\text { quienes han alcanzado la edad legal } \\
\text { para dejar de trabajar, que no son } \\
\text { necesariamente personas mayores }\end{array}$ \\
\hline Población mayor (subgrupo de & Tercera Edad: \\
\hline edad a partir de los 60 y más & A partir de la segunda asamblea \\
\hline - Adultos (as) mayores jóvenes: 60 & de Madrid en el 2002, esta \\
\hline a 74 años. & expresión se ha ido revaluando y lo \\
\hline - Adultos (as) mayores viejos: 75 a & correcto sería referirse a esta etapa \\
\hline - Adultos (as) mayores longevos: & personas mayores. \\
\hline 85 a 99 años. & \\
\hline - Centenarios (as):100 años y más. & \\
\hline
\end{tabular}

Nota: Adaptado de "Guía para periodistas. Vejez y envejecimiento" por Fundación Saldarriaga Concha, 2013, p.9 


\section{Anexo 5. Situación de la población adulta mayor en el Perú}

\begin{tabular}{|c|c|}
\hline Ítems & Resumen \\
\hline Mortalidad & Dos mujeres por varón a partir de los 85 años. \\
\hline PAM en hogares & $\begin{array}{l}\text { El } 42,7 \% \text { de los hogares peruanos tienen entre sus miembros } \\
\text { al menos una persona mayor. En Lima Metropolitana, el } 44 \% \\
\text { de hogares. }\end{array}$ \\
\hline Jefes de hogar & $\begin{array}{l}\text { El 27,3\% de hogares del país son conducidos por una persona } \\
\text { mayor. Según el sexo, más mujeres son cabeza de hogar. }\end{array}$ \\
\hline Educación & $\begin{array}{l}\text { El 38,2\% cuenta con un nivel educativo de nivel primaria; } \\
24,3 \% \text { secundaria y } 22,4 \% \text {, nivel superior ( } 14,9 \% \text { superior } \\
\text { universitaria y } 7,5 \% \text { superior no universitaria). }\end{array}$ \\
\hline Alfabetización & $\begin{array}{l}\text { El } 17,8 \% \text { de la población mayor no sabe leer ni escribir. Esta } \\
\text { situación es más elevada en las mujeres mayores }(26,7 \%) \\
\text { siendo más de tres veces que en los hombres }(7,8 \%) \text {. }\end{array}$ \\
\hline $\begin{array}{l}\text { Tipo de seguro de } \\
\text { salud }\end{array}$ & $\begin{array}{l}\text { El } 39,5 \% \text { de las personas mayores acceden al Seguro Integral } \\
\text { de Salud (SIS) y el } 36,1 \% \text { solo a EsSalud. }\end{array}$ \\
\hline Pensión & $\begin{array}{l}\text { E } 38,3 \% \text { de la población mayor está afiliado a un sistema de } \\
\text { pensión. El 18,1\% está afiliado a la Oficina de Normalización } \\
\text { Previsional (ONP), seguido por el } 12,0 \% \text { de afiliados a las } \\
\text { Administradoras de Fondos de Pensiones (AFP). }\end{array}$ \\
\hline Salud & $\begin{array}{l}\text { El } 81,3 \% \text { de la población adulta mayor femenina presentó } \\
\text { algún problema de salud crónico. En la población masculina, } \\
\text { este problema de salud afecta al } 71,0 \% \text {. }\end{array}$ \\
\hline Discapacidad & $\begin{array}{l}\text { Del total de la población que padece alguna discapacidad el } \\
46,9 \% \text { son adultos mayores. Según el tipo de discapacidad } \\
\text { que afecta a la población adulta mayor, el } 32,9 \% \text { tiene } \\
\text { dificultad para usar brazos y piernas, el 14,3\% dificultad para } \\
\text { ver, el } 12,0 \% \text { para oír y el 5,8\% para entender o aprender, } \\
\text { entre los principales. En tanto, el 32,9\% de los adultos } \\
\text { mayores discapacitados tienen dos o más discapacidades. }\end{array}$ \\
\hline Internet & $\begin{array}{l}\text { Para el trimestre de análisis, la población adulta mayor que } \\
\text { hace uso de Internet es de } 22,4 \% \text {, en el caso de los hombres } \\
\text { el } 25,7 \% \text { usa Internet, mientras que en el caso de las mujeres } \\
\text { solo el } 19,4 \% \text { usa. }\end{array}$ \\
\hline
\end{tabular}

Nota: Adaptado de "Informe técnico sobre la Situación de la Población Adulta Mayor" por INEI, 2019. 
Anexo 6. Marco Normativo Internacional

\begin{tabular}{|c|c|c|}
\hline Año & Entidad & Documento \\
\hline 1952 & OIT & $\begin{array}{l}\text { Convenio número } 102 \text { - Convenio relativo a la } \\
\text { norma mínima de la seguridad social (Entrada en } \\
\text { vigor: } 27 \text { abril 1955), y Recomendación número } \\
\text { 202, sobre pisos de protección social }\end{array}$ \\
\hline 1982 & ONU & $\begin{array}{l}\text { Primera Asamblea Mundial sobre el } \\
\text { Envejecimiento. Aprueba el "Plan de Acción } \\
\text { Internacional sobre el envejecimiento" }\end{array}$ \\
\hline 1991 & ONU & $\begin{array}{l}\text { Se aprueban los "Principios de las Naciones } \\
\text { Unidas en favor de las personas de edad" }\end{array}$ \\
\hline 1992 & ONU & $\begin{array}{l}\text { Se aprueba la "Proclamación sobre el } \\
\text { envejecimiento" }\end{array}$ \\
\hline 1999 & ONU & $\begin{array}{l}\text { Año internacional de las personas de edad: "Hacia } \\
\text { una sociedad para todas las edades" Se aprueba el } \\
\text { "Marco de políticas para una sociedad para todas } \\
\text { las edades" y el "Programa de Investigación para } \\
\text { el envejecimiento para el siglo XXI". }\end{array}$ \\
\hline 2002 & ONU & $\begin{array}{l}\text { Segunda Asamblea Mundial sobre el } \\
\text { Envejecimiento: "Construir una sociedad para } \\
\text { todas las edades". Aprueba una "Declaración } \\
\text { Política" y el "Plan internacional a largo plazo } \\
\text { sobre el envejecimiento". }\end{array}$ \\
\hline 2003 & $\begin{array}{l}\text { CEPAL y Grupo } \\
\text { Interinstitucional } \\
\text { sobre } \\
\text { Envejecimiento }\end{array}$ & $\begin{array}{l}\text { Primera Conferencia Regional } \\
\text { Intergubernamental sobre Envejecimiento: "Hacia } \\
\text { una estrategia regional de implementación para } \\
\text { América Latina y el Caribe del Plan de Acción } \\
\text { Internacional de Madrid sobre el } \\
\text { Envejecimiento". Aprueba la "Estrategia } \\
\text { Regional de Implementación para América Latina } \\
\text { y el Caribe". }\end{array}$ \\
\hline 2007 & $\begin{array}{l}\text { CEPAL y Grupo } \\
\text { Interinstitucional } \\
\text { sobre } \\
\text { Envejecimiento }\end{array}$ & $\begin{array}{l}\text { Segunda Conferencia: "Hacia una sociedad para } \\
\text { todas las edades y de protección social basada en } \\
\text { derechos". Aprueba "Declaración de Brasilia". }\end{array}$ \\
\hline 2010 & OEA & $\begin{array}{l}\text { Sesión extraordinaria del Consejo Permanente de } \\
\text { la Organización de Estados Americanos sobre } \\
\text { derechos humanos y personas mayores }\end{array}$ \\
\hline 2012 & $\begin{array}{l}\text { CEPAL y Grupo } \\
\text { Interinstitucional } \\
\text { sobre } \\
\text { Envejecimiento }\end{array}$ & $\begin{array}{l}\text { Tercera Conferencia: "Envejecimiento, } \\
\text { solidaridad y protección social: la hora de avanzar } \\
\text { hacia la igualdad". Aprueba la "Carta de San José } \\
\text { sobre los derechos de las personas mayores de } \\
\text { América Latina y el Caribe" }\end{array}$ \\
\hline 2013 & OEA & $\begin{array}{l}\text { Se aprueba la "Convención Interamericana sobre } \\
\text { la Protección de los Derechos Humanos de las } \\
\text { Personas Mayores". Entró en vigor en diciembre } \\
\text { de } 2016 \text { con la ratificación por dos países: } \\
\text { Uruguay y Costa Rica. Luego de esa fecha fue }\end{array}$ \\
\hline
\end{tabular}


2017

CEPAL y Grupo

ratificada también por Bolivia y Chile. En el caso del Perú la ratificación se encuentra en proceso, pero todavía no se concreta.

Interinstitucional Cuarta Conferencia Regional Intergubernamental sobre sobre Envejecimiento y Derechos de las Personas Mayores de América Latina y el Caribe. Aprueba Envejecimiento "Declaración de Asunción: Construyendo sociedades inclusivas: envejecimiento con dignidad y derechos."

Nota. Adaptado de "Envejecimiento con Dignidad: Una mirada a los derechos de las personas adultas mayores en el Perú" por Mesa de Concertación para la Lucha contra la Pobreza, 2018, pp.9-100 
Anexo 7. Marco Normativo Nacional

\begin{tabular}{|c|c|c|}
\hline Año & Entidad & Documento \\
\hline 2000 & PROMUDEH & $\begin{array}{l}\text { Decreto Supremo N }{ }^{\circ} 010-2000- \\
\text { PROMUDEH. Aprueba "Lineamientos de } \\
\text { política para las personas adultas mayores". }\end{array}$ \\
\hline 2006 & $\begin{array}{l}\text { Congreso de la } \\
\text { República }\end{array}$ & $\begin{array}{l}\text { Ley 28803, Ley de las Personas Adultas } \\
\text { Mayores. }\end{array}$ \\
\hline 2006 & MIMDES & $\begin{array}{l}\text { Decreto Supremo N }{ }^{\circ} 006-2006-M I M D E S . \\
\text { Aprueba "Plan Nacional para las Personas } \\
\text { Adultas Mayores 2006-2010". }\end{array}$ \\
\hline 2006 & MIMDES & $\begin{array}{l}\text { Decreto Supremo No } 013-2006-M I M D E S . \\
\text { Aprueba "Reglamento de la Ley No } 28803 \text { - } \\
\text { Ley de las Personas Adultas Mayores". }\end{array}$ \\
\hline 2006 & $\begin{array}{l}\text { Congreso de la } \\
\text { República }\end{array}$ & $\begin{array}{l}\text { LEY 28683. Ley que Modifica la Ley N } \\
\text { 27408, Ley que Establece la Atención } \\
\text { Preferente de las Mujeres Embarazadas Niñas } \\
\text { y Niños, Adultos Mayores de Atención al } \\
\text { Público. }\end{array}$ \\
\hline 2006 & MINSA & $\begin{array}{l}\text { Resolución Ministerial N 529-2006-MINSA. } \\
\text { Aprueba "Norma Técnica de Salud para la } \\
\text { Atención Integral de Salud de las Personas } \\
\text { Adultas Mayores". }\end{array}$ \\
\hline 2007 & MINDES & $\begin{array}{l}\text { Resolución Ministerial No 613-2007- } \\
\text { MIMDESAprueba "Pautas y } \\
\text { Recomendaciones para el Funcionamiento de } \\
\text { los Centros Integrales de Atención al Adulto } \\
\text { Mayor (CIAM)". }\end{array}$ \\
\hline 2010 & MIMDES & $\begin{array}{l}\text { Decreto Supremo N 009-2010-MIMDES. } \\
\text { Aprueba "Requisitos Mínimos para el } \\
\text { Funcionamiento de los Centros de Atención } \\
\text { Residencial para las Personas Adultas } \\
\text { Mayores (CARPAM)". }\end{array}$ \\
\hline 2011 & MIMDES & $\begin{array}{l}\text { Decreto Supremo No 011-2011-MIMDES. } \\
\text { Aprueba "Política Nacional en relación con } \\
\text { las Personas Adultas Mayores". }\end{array}$ \\
\hline 2011 & $\begin{array}{c}\text { Presidencia del Consejo } \\
\text { de Ministros }\end{array}$ & $\begin{array}{l}\text { Decreto Supremo No 081-2011-PCM. Crea el } \\
\text { "Programa Social denominado Programa } \\
\text { Nacional de Asistencia Solidaria- Pensión } \\
65 "\end{array}$ \\
\hline 2012 & MIMP & $\begin{array}{l}\text { Decreto Supremo No 006-2012-MIMP. Crea } \\
\text { el "Programa Vida Digna" }\end{array}$ \\
\hline 2013 & $\begin{array}{l}\text { Congreso de la } \\
\text { República }\end{array}$ & $\begin{array}{l}\text { Ley } N^{\circ} 30088 \text {, Ley que declara el } 26 \text { de } \\
\text { agosto de cada año, como Día Nacional de } \\
\text { las Personas Adultas Mayores. }\end{array}$ \\
\hline 2013 & MIMP & $\begin{array}{l}\text { Decreto Supremo N } \text { N }^{\circ} 02-2013-\text { MIMP. } \\
\text { Aprueba "Plan Nacional Para las Personas } \\
\text { Adultas Mayores 2013-2017" }\end{array}$ \\
\hline 2014 & MINSA & $\begin{array}{l}\text { Resolución Ministerial N }{ }^{\circ} 756-2014-M I N S A . \\
\text { Aprueba el Documento Técnico }\end{array}$ \\
\hline
\end{tabular}




$\begin{array}{cc}2015 & \text { MEF } \\ & \\ 2016 & \begin{array}{c}\text { Congreso de la } \\ \text { República } \\ \end{array} \\ 2017 & \text { MIMP }\end{array}$

"Organización de los Círculos de Adultos Mayores en los Establecimientos de Salud del Primer Nivel de Atención" Directiva N 001-2015-EF/50.01 “Directiva para los Programas Presupuestales en el Marco de la Programación y Formulación del Presupuesto del Sector Público para el Año Fiscal 2016", en la cual se incluye el nuevo Programa Presupuestal No 142: "Acceso de Personas Adultas Mayores a Servicios Especializados" Ley 30490, Ley de la Persona Adulta Mayor (reemplaza la anterior del año 2006) Reglamento de la Ley 30490 en proceso de consulta.

Nota. Adaptado de "Envejecimiento con Dignidad: Una mirada a los derechos de las personas adultas mayores en el Perú" por Mesa de Concertación para la Lucha contra la Pobreza, 2018, pp.100-101 
Anexo 8. Otros Servicios a favor de las PAM

\begin{tabular}{|c|c|c|}
\hline Servicios & Entidad & Propósito \\
\hline $\begin{array}{l}\text { Centros de } \\
\text { Atención } \\
\text { Residencial para } \\
\text { Personas Adultas } \\
\text { Mayores } \\
\text { (CARPAM) }\end{array}$ & MIMP & $\begin{array}{l}\text { Albergues para personas adultas } \\
\text { mayores que brindan apoyo social, } \\
\text { médico y psicológico a sus residentes }\end{array}$ \\
\hline $\begin{array}{l}\text { Clubes del Adulto } \\
\text { Mayor }\end{array}$ & INABIF - MIMP & $\begin{array}{l}\text { Dirigido a las PAM de } 60 \text { años que } \\
\text { se encuentren en situación de } \\
\text { pobreza, pobreza extrema o } \\
\text { abandono familiar. Busca } \\
\text { proporcionar a las personas adultas } \\
\text { mayores un conjunto de actividades } \\
\text { de recreación y esparcimiento para } \\
\text { compartir experiencias, elevar su } \\
\text { autoestima y mejorar su calidad de } \\
\text { vida. }\end{array}$ \\
\hline $\begin{array}{l}\text { Centros } \\
\text { Especializados de } \\
\text { Referencia para } \\
\text { Adultos Mayores } \\
\text { (CERPAM) }\end{array}$ & INABIF & $\begin{array}{l}\text { Promueven la participación de } \\
\text { personas adultas mayores en los } \\
\text { servicios de orientación psicológica, } \\
\text { social, médica, nutricional, terapia } \\
\text { física, consejería para una vida } \\
\text { saludable, odontología y otros } \\
\text { servicios que se brindan en } \\
\text { coordinación con los gobiernos } \\
\text { locales }\end{array}$ \\
\hline $\begin{array}{l}\text { Centros del Adulto } \\
\text { Mayor (CAM) }\end{array}$ & MINSA & $\begin{array}{l}\text { mejorar el proceso del } \\
\text { envejecimiento mediante el } \\
\text { desarrollo de programas gratuitos de } \\
\text { integración familiar, } \\
\text { intergeneracional, socioculturales, } \\
\text { recreativos, productivos y de estilos } \\
\text { de vida para un envejecimiento } \\
\text { activo. }\end{array}$ \\
\hline $\begin{array}{l}\text { Círculos del Adulto } \\
\text { Mayor (CIRAM) }\end{array}$ & Essalud & $\begin{array}{l}\text { Servicio gerontológico social que } \\
\text { brinda a las PAM aseguradas, } \\
\text { organizados en asociaciones en } \\
\text { zonas geográficas donde no existe un } \\
\text { Centro del Adulto Mayor - CAM. }\end{array}$ \\
\hline
\end{tabular}

Nota. Adaptado de "Envejecimiento con Dignidad: Una mirada a los derechos de las personas adultas mayores en el Perú" por Mesa de Concertación para la Lucha contra la Pobreza, 2018, pp.79-82 
Anexo 9. Resultados Cuantitativos - Cuestionario realizado a la comunidad

El instrumento fue aplicado a una muestra de 30 personas que viven en el distrito de Carabayllo de la ciudad de Lima Metropolitana. Con el objetivo de conocer la percepción de la imagen de la vejez en la comunidad.

La encuesta se realizó por medio de un formulario de Google, el cual fue compartido de manera digital. Dicha herramienta consta de 14 preguntas cerradas,

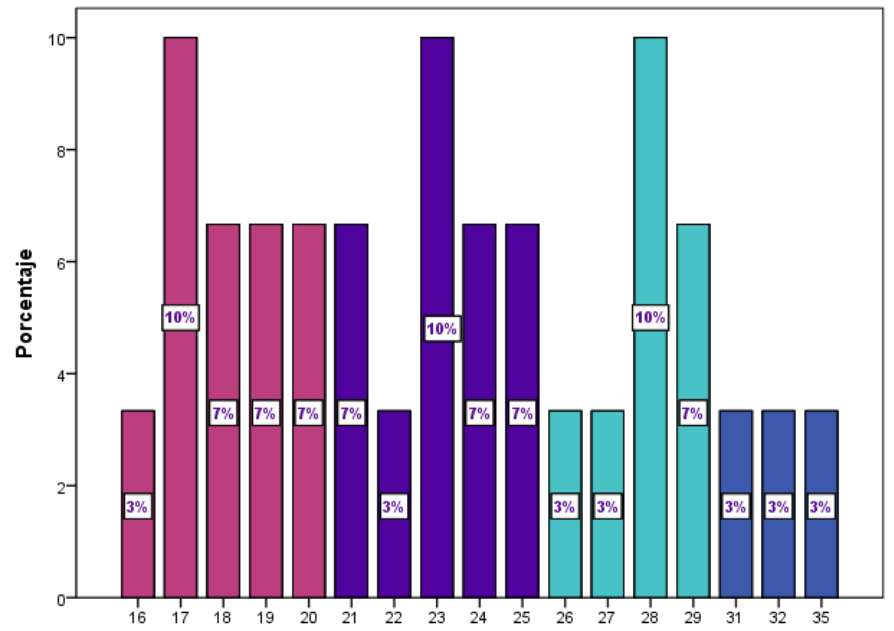

Figura 39. Edad de los encuestados. Encuesta realizada para la presente investigación, 2019.

Según lo observado, el rango de edades de los participantes esta entre los 16 a 35 años.

Siendo el 10\% de los encuestados respectivamente las edades 17, 23 y 28.

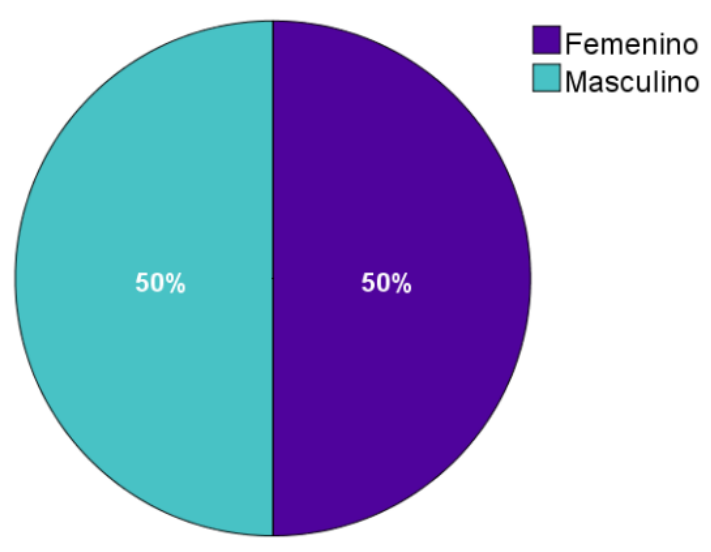

Figura 40. Género de los encuestados. Encuesta realizada para la presente investigación, 2019. 
Como se puede observar en la figura 40, en los resultados obtenidos de la encuesta para conocer la percepción de la imagen de la vejez en la comunidad, del total de los encuestados, el $50 \%$ fueron hombres y el $50 \%$ fueron mujeres.

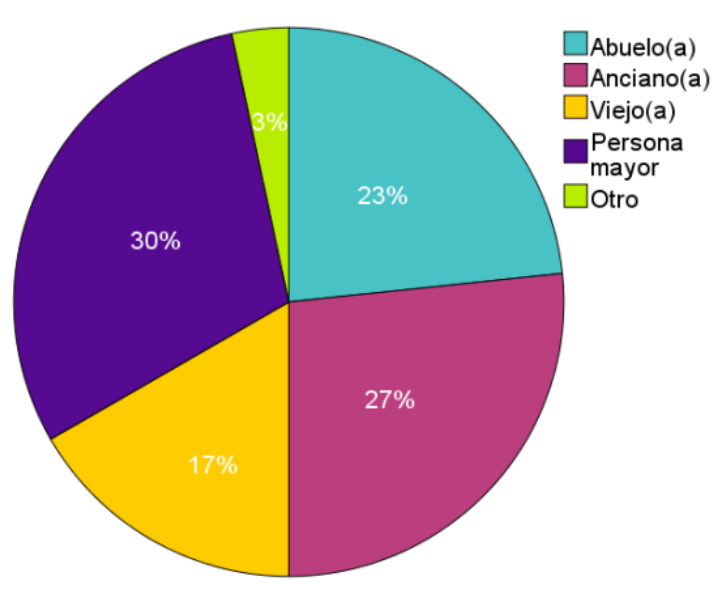

Figura 41. Término con el que se refieren a una «persona adulta mayor». Encuesta realizada para la presente investigación, 2019.

Como se puede observar en la figura 41, en los resultados obtenidos de la encuesta para conocer el término con el que se refieren a una persona adulta mayor, el 30\% de los encuestados indican que se refieren a ellos como "persona mayor", el 26,7\% como “anciano(a)", el 23,3\% como "abuelo(a)", el 16, 7\% como “viejo(a)" y el 3,3\% utiliza otro termino.

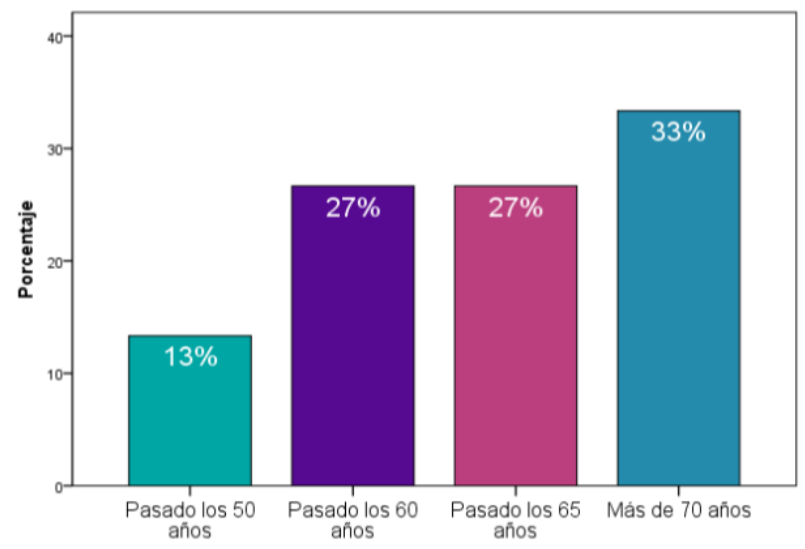

Figura 42. Edad en la que consideran que se es una persona adulta mayor. Encuesta realizada para la presente investigación, 2019. 
Como se puede observar en la figura 42, en los resultados obtenidos de la encuesta para conocer la edad que los encuetados creen que una persona es considerada persona adulta mayor, el 33,3\% considera que se es pasado los 70 años. El 26,7\% consideran que son pasados los 60 años y otro 26,7\% que son pasados los 65 años. Por el contrario, el 13,3\% consideran que son pasados los 50 años.

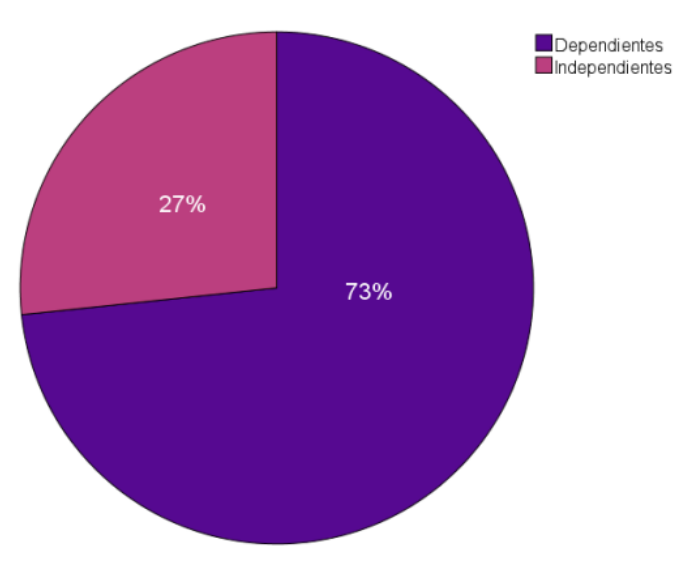

Figura 43. Percepción de las personas mayores: dependiente o independiente. Encuesta realizada para la presente investigación, 2019.

Como se puede observar en la figura 43, en los resultados obtenidos de la encuesta para conocer la percepción de la imagen de la vejez en la comunidad, el 73,3\% de los encuestados consideran a las personas mayores como personas dependientes, mientras que solo el $26,7 \%$ los considera como independientes.

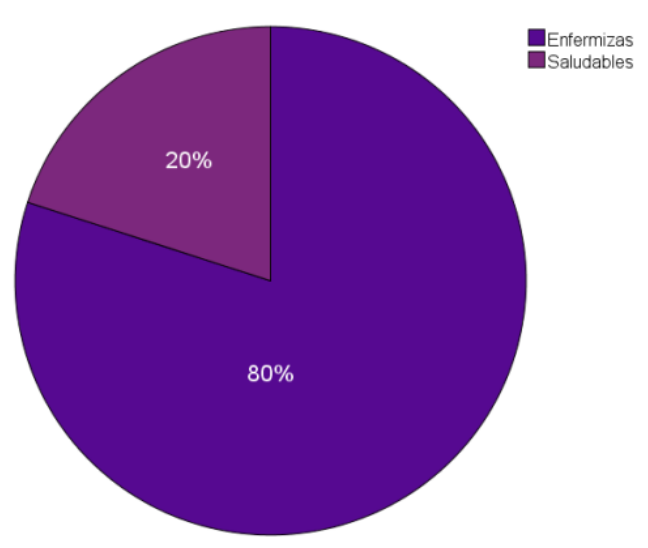

Figura 44. Percepción de las personas mayores: enfermizas o saludables. Encuesta realizada para la presente investigación, 2019. 
Como se puede observar en la figura 44, en los resultados obtenidos de la encuesta para conocer la percepción de la imagen de la vejez en la comunidad, el 80\% de los encuestados consideran a las personas mayores como personas enfermizas, mientras que solo el $20 \%$ los considera como saludables.

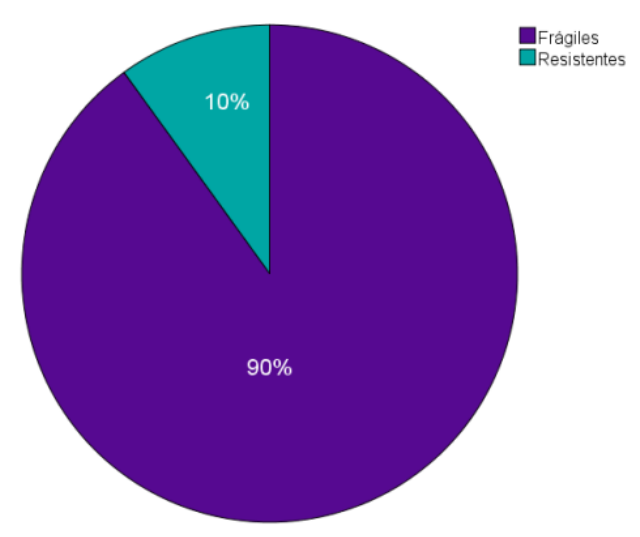

Figura 45. Percepción de las personas mayores: frágiles o resistentes. Encuesta realizada para la presente investigación, 2019.

Como se puede observar en la figura 45, en los resultados obtenidos de la encuesta para conocer la percepción de la imagen de la vejez en la comunidad, el 90\% de los encuestados consideran a las personas mayores como personas frágiles, mientras que solo el $10 \%$ los considera como resistentes.

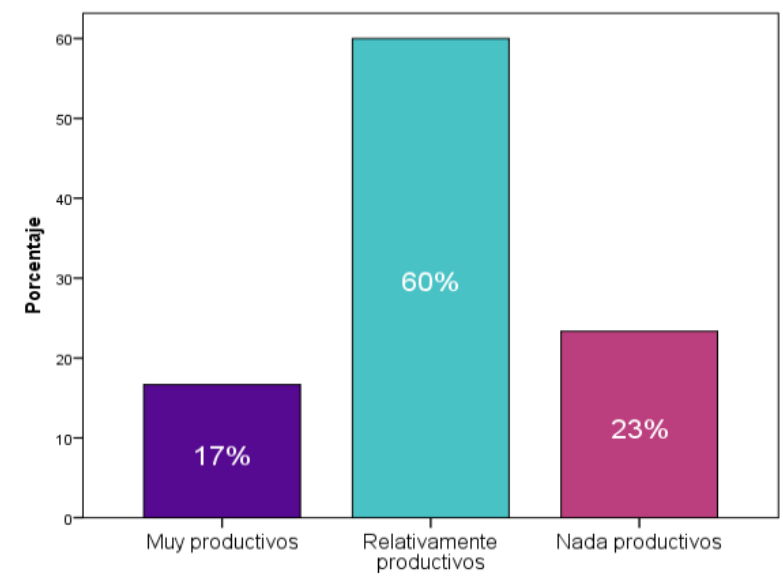

Figura 46. Percepción sobre la productividad de las personas mayores. Encuesta realizada para la presente investigación, 2019. 
Como se puede observar en la figura 46, en los resultados obtenidos de la encuesta para conocer la percepción de productividad de las personas mayores, el 60\% de los encuestados consideran a las personas mayores como relativamente productivos, mientras que el 23,3\% los considera como nada productivos. Y solo el $16,7 \%$ los considera muy productivos.

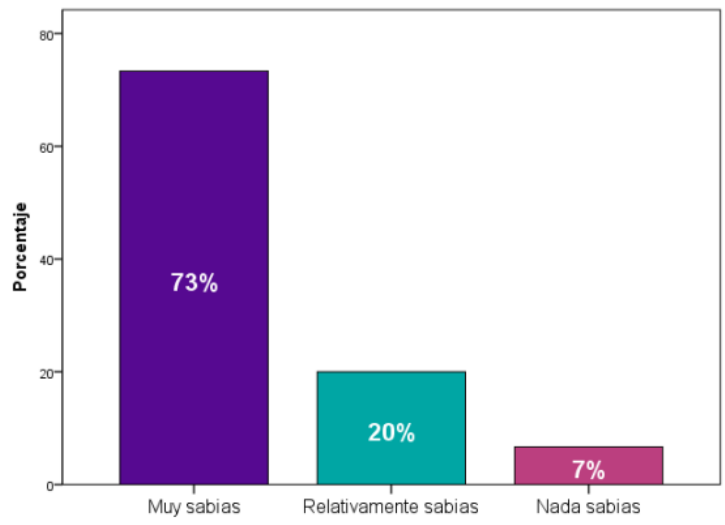

Figura 47. Percepción sobre la sabiduría de las personas mayores. Encuesta realizada para la presente investigación, 2019.

Como se puede observar en la figura 47, en los resultados obtenidos de la encuesta para conocer la percepción sobre la sabiduría de las personas mayores, el 73,3\% de los encuestados consideran a las personas mayores son muy sabias, mientras que el $20 \%$ los considera relativamente sabias. Y solo el 6,7\% los considera nada sabios.

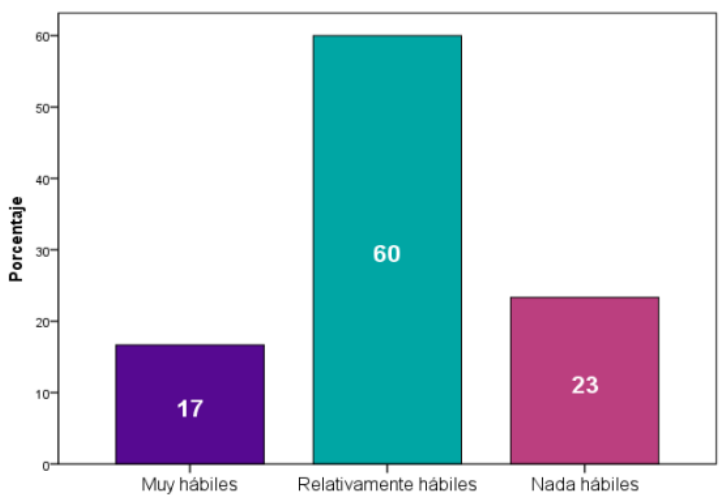

Figura 48. Percepción sobre la habilidad de las personas mayores. Encuesta realizada para la presente investigación, 2019. 
Como se puede observar en la figura 48 , en los resultados obtenidos de la encuesta para conocer la percepción sobre la habilidad de las personas mayores, el $60 \%$ de los encuestados consideran a las personas mayores son relativamente sabias, mientras que el $23 \%$ los considera nada hábiles. Y solo el 17\% los considera muy hábiles.

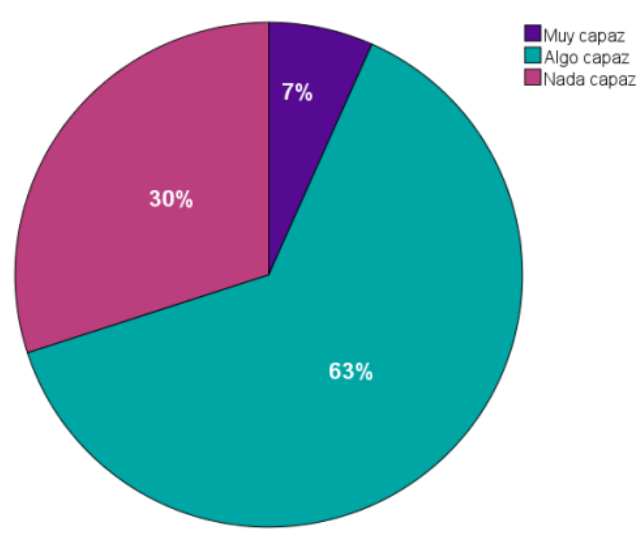

Figura 49. Percepción sobre la capacidad de las personas mayores para adaptarse a los cambios. Encuesta realizada para la presente investigación, 2019.

Como se puede observar en la figura 49, en los resultados obtenidos de la encuesta para conocer la percepción sobre la capacidad de las personas mayores para adaptarse a los cambios, el $63 \%$ de los encuestados consideran a las personas mayores son algo capaz, mientras que el 30\% los considera nada capaz. Y solo el 7\% los considera algo capaz.

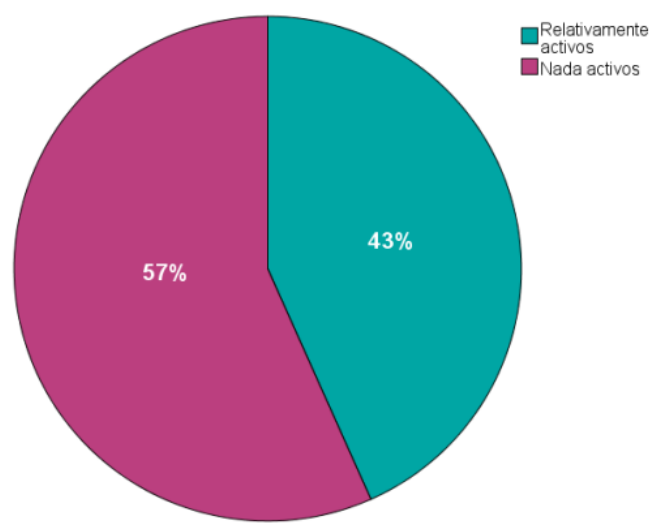

Figura 50. Percepción sobre qué tan activos sexualmente son las personas mayores. Encuesta realizada para la presente investigación, 2019. 
Como se puede observar en la figura 50, en los resultados obtenidos de la encuesta para conocer qué tan activos sexualmente son las personas mayores, el 57\% de los encuestados consideran a las personas mayores como nada activos, mientras que el $43 \%$ los considera nada activos.

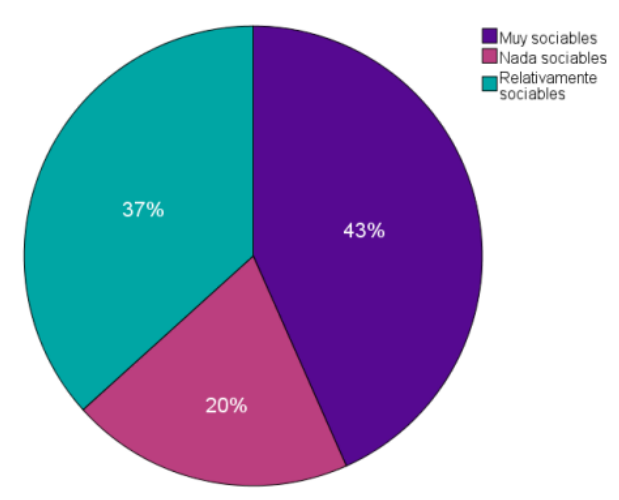

Figura 51. Percepción qué tan sociables son las personas mayores. Encuesta realizada para la presente investigación, 2019.

Como se puede observar en la figura 51, en los resultados obtenidos de la encuesta para conocer qué tan sociables son las personas mayores, el $43 \%$ de los encuestados consideran a las personas mayores son muy sociables, mientras que el $37 \%$ los considera relativamente sociables. Y solo el $20 \%$ los considera nada sociables.

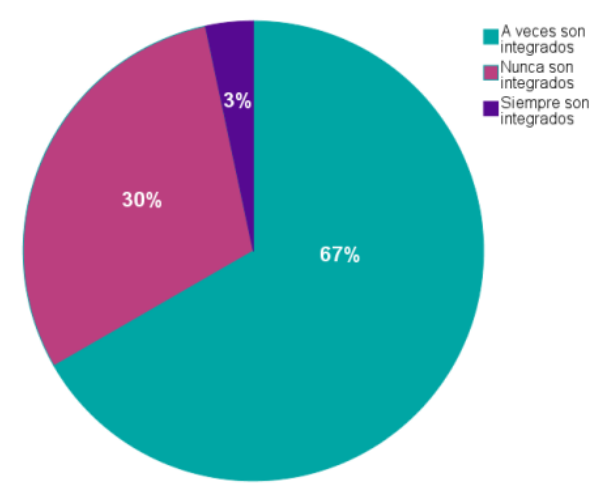

Figura 52. Percepción sobre la integración de las personas mayores en la sociedad. Encuesta realizada para la presente investigación, 2019.

Como se puede observar en la figura 52, en los resultados obtenidos de la encuesta para conocer percepción sobre la integración de las personas mayores en la sociedad, el 67\% de 
los encuestados consideran que a veces son integrados, mientras que el $30 \%$ considera que nunca son integrados. Y solo el 3\% considera que siempre son integrados.

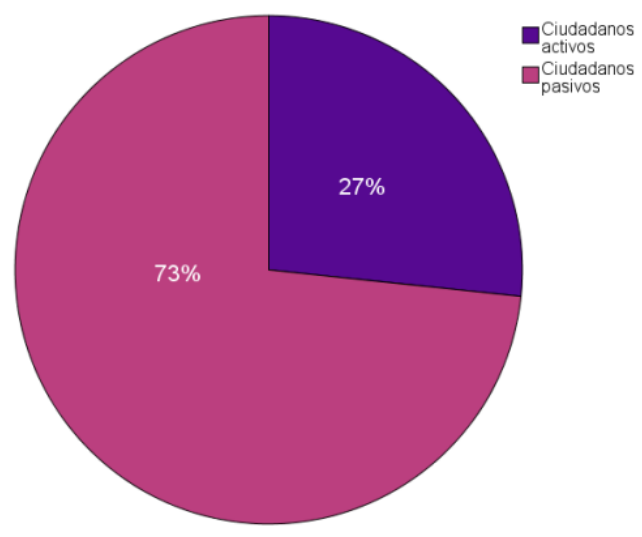

Figura 53. Percepción sobre las personas mayores: pasivos o activos. Encuesta realizada para la presente investigación, 2019.

Como se puede observar en la figura 53, en los resultados obtenidos de la encuesta para conocer la percepción sobre las personas mayores, el 73\% de los encuestados los consideran ciudadanos pasivos, mientras que solo el $27 \%$ los consideran ciudadanos activos.

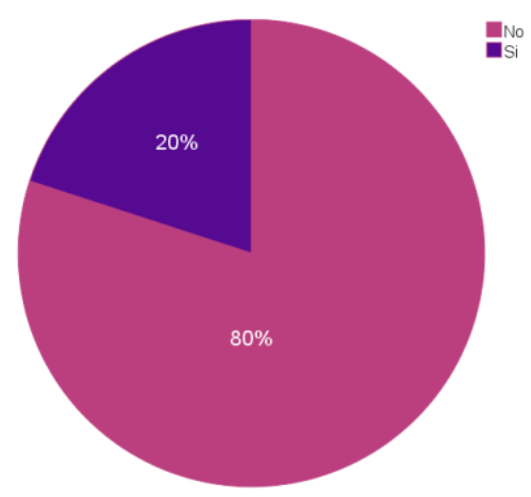

Figura 54. Valoración de las personas mayores. Encuesta realizada para la presente investigación, 2019.

Como se puede observar en la figura 54, en los resultados obtenidos de la encuesta para conocer la percepción de las personas mayores, el $80 \%$ de los encuestados consideran que las personas mayores no son valoradas, mientras que solo el $20 \%$ si las consideran valoradas. 
Anexo 10. Transcripción de las entrevistas a los PAM

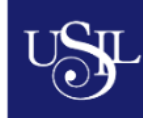

UNIVERSIDAD
SAN IGNACIO SAN IGNACIO
DE LOYOLA
ENTREVISTA A LA PERSONA MAYOR RESPECTO A LA IMAGEN DE LA VEJEZ Y DE LA PERSONA MAYOR
Maestría en

Diseño Gráfico

Fecha: 06/10/2019 Hora: 10:50 am Entrevistador: Dayra Ita Sarrin

Datos del entrevistado

Nombre: Julio Villanueva

Edad: 78 Género: $\quad \mathrm{M}$

$\square \mathrm{F}$

La siguiente entrevista pretende conocer la apreciación del adulto mayor respecto a la experiencia vivida, de tal manera se pueda complementar la información recopilada, en las encuestas realizadas.

\section{Lista de Preguntas}

1. Dime tu nombre, edad, profesión u oficio.

Julio Villanueva, jubilado, 78 años

2. ¿Sientes que a veces te tratan como a un niño pequeño?

No

3. ¿Qué es lo que más echas de menos de tu juventud?

La compañía, ir a reuniones, donde me encontraba con mis amigos. Ahora con los amigos me encuentro después de dos a tres meses, además los amigos que había antes, pues, ya no están, están bajo tierra.

4. ¿Qué es lo mejor que se ha inventado desde que naciste?

La unión, que todos tengan facilidad de tener trabajo.

5. ¿Tienes familia?

Si

6. ¿Con qué personas vives actualmente?

Con mi esposa, mis hijos están afuera. 
7. ¿Qué cosas dejan de preocuparte cuando te haces mayor?

Antes, mi preocupación eran mis hijos, darle una educación. Hoy en día, me preocupa mi salud, que, de un momento a otro, me dé una enfermedad, como una que me bajo la vista.

8. ¿Ha dejado de hacer algo que antes hacías?

Me gustaba estar colaborando en el trabajo, tener algo que hacer.

9. ¿Qué haces con tanto tiempo libre?

$\mathrm{Si}$, salgo un rato, un par de horas, como siempre me quedo solo, me quedo viendo televisión, converso con mi mujer, o a veces mientras ella teje me pongo a ver temas de la política.

10. ¿Te sientes útil?

De acuerdo con como estoy, por ahí como se puede hacer un esfuerzo, según lo que yo pueda.

11. ¿Tienes algún sueño por cumplir?

No, el único sueño es el del cajón.

12. ¿Te sientes solo?

No, solo no, tengo a mi familia, mis hijos, nietos, aunque ahorita no están acá, porque están lejos.

13. ¿En algún momento te has sentido discriminado por ser mayor?

La discriminación no existe. Al contrario, cuando estoy en el bus me seden el asiento.

14. ¿Pertenece a algún club, grupo o casa para adulto mayor?

Si, pero no aquí, muy aparte, en Ica. 


\section{ENTREVISTA A LA PERSONA MAYOR RESPECTO A LA IMAGEN DE LA VEJEZ Y DE LA PERSONA MAYOR}

Maestría en

Diseño Gráfico

Fecha: 06/10/2019 Hora: 11:10 am Entrevistador: Dayra Ita Sarrin

Datos del entrevistado

Nombre: Robinson Dávila

Edad: 60 Género: $\quad \mathrm{M}$ $\mathrm{F}$

La siguiente entrevista pretende conocer la apreciación del adulto mayor respecto a la experiencia vivida, de tal manera se pueda complementar la información recopilada, en las encuestas realizadas.

\section{Lista de Preguntas}

1. Dime tu nombre, edad, profesión u oficio.

Robinson Joaquín Dávila Arancibia, 60, dibujante de arquitectura

2. ¿Sientes que a veces te tratan como a un niño pequeño?

Mayormente mi familia me subestima mucho, no aceptan la edad que tengo, yo les digo que ya tengo 60 años, cuando no vengo a las $11 \mathrm{pm}$ me están llamando al celular. Yo no soy una criatura. Yo ya me siento como una persona adulta. No necesito que me estén chequeando, preocupándose.

3. ¿Qué es lo que más echas de menos de tu juventud?

El trabajo, me gustaba cuando terminaba un trabajo era felicitado por los ingeniero y arquitectos. Cuando me enviaban un trabajo me mandaban al sitio para ver le terreno y hacer el plano. Pero a mí siempre me decían que yo podría tender una profesión o una empresa. No me gustaba que me estén corrigiendo.

4. ¿Qué es lo mejor que se ha inventado desde que naciste?

La cura para el cáncer, en todas sus dimensiones.

5. ¿Tienes familia?

$\mathrm{Si}$, mi esposa y una hija, aunque no vive conmigo.

6. ¿Con qué personas vives actualmente?

Ahorita, yo vivo solo, mi hija vive con su mamá en su casa. 
7. ¿Qué cosas dejan de preocuparte cuando te haces mayor?

(no respondió)

8. ¿Ha dejado de hacer algo que antes hacías?

$\mathrm{Si}$, el trabajo, eso me encantaba, porque en ese tiempo no me gustaba estar ocioso. No me gustaba estar en mi casa. Prefería ir a trabajar los domingos.

9. ¿Qué haces con tanto tiempo libre?

Ya no trabajo, pero sigo por mi cuenta yendo a la oficina, le pido trabajos a los ingenieros, les pido que me den algunos planos modernos peor les pido algo para hacer. Cuando cumplí 60, me dijeron que tu pulso no será igual cuando era joven, y aquí lo que necesitamos es la perfección en el trabajo de la arquitectura. Las manos empiezan a temblar, tu visión empieza a fallar y eso es lo que más se necesitan.

10. ¿Te sientes útil?

En realidad, me deprimo. En el trabajo me dan para hacer correcciones en los planos, pero ya no me dan para hacer como antes. Siento yo que lo hacen de pena, para que yo no me deprima, para no decirme que descanse en mi vejez, que disfrute con mi hija. Por lo que ellos me dan algunas cosas para que no me deprima.

11. ¿Tienes algún sueño por cumplir?

Yo siempre quise tener mi propia empresa de arquitectura. Cuando fui joven me alababan los arquitectos e ingenieros. Me decían que yo era el más detallista, el mejor de los dibujantes. Me dijeron que podría tener mi propia empresa.

12. ¿Te sientes solo?

Si me siento solo.

13. ¿En algún momento te has sentido discriminado por ser mayor?

$\mathrm{Si}$, yo siento que me dan trabajo, para que la vejez no te agarra y te damos trabajo. Si (en la calle) me tuve que acostumbrar a la marginación.

14. ¿Pertenece a algún club, grupo o casa para adulto mayor?

No, pero me gustaría. Me gustaría hacer terapias. 
Fecha: 06/10/2019 Hora: 11:52 am Entrevistador: Dayra Ita Sarrin

Datos del entrevistado

Nombre: Felipe Montes de Oca Edad: 80 Género: $\quad$ M $\quad \square$ F

La siguiente entrevista pretende conocer la apreciación del adulto mayor respecto a la experiencia vivida, de tal manera se pueda complementar la información recopilada, en las encuestas realizadas.

\section{Lista de Preguntas}

1. Dime tu nombre, edad, profesión u oficio.

Felipe Montes de Oca Figueroa, 80, gasfitero

2. ¿Sientes que a veces te tratan como a un niño pequeño?

No, es que uno debe demostrar con su trabajo que no lo traten como niño

3. ¿Qué es lo que más echas de menos de tu juventud?

La energía, habilidad

4. ¿Qué es lo mejor que se ha inventado desde que naciste?

El colegio

5. ¿Tiene familia?

Si, mi esposa, hijos y nietos

6. ¿Con qué personas vives actualmente?

Mi esposa, hijos y nietos

7. ¿Qué cosas dejan de preocuparte cuando te haces mayor?

La economía, lo que concierne a la casa.

8. ¿Ha dejado de hacer algo que antes hacías? 
No, en cualquier momento yo trabajo.

9. ¿Qué haces con tanto tiempo libre?

Mirar tele, descansar un rato o dormir.

10. ¿Te sientes útil?

Por supuesto, ¿para qué me voy a sentir inútil? Siempre hay que estar en actividad

11. ¿Tienes algún sueño por cumplir?

No ya no, hay que descansar, habría que vivir más tiempo

12. ¿Te sientes solo?

No

13. ¿En algún momento te has sentido discriminado por ser mayor?

No, no he sentido

14. ¿Pertenece a algún club, grupo o casa para adulto mayor?

No nada, nada. 
ENTREVISTA A LA PERSONA MAYOR RESPECTO A LA IMAGEN DE LA VEJEZ Y DE LA PERSONA MAYOR

Fecha: 06/10/2019 Hora: 12:05 p.m. Entrevistador: Dayra Ita Sarrin

Datos del entrevistado

Nombre: Alberto Mendiola $\quad$ Edad: $67 \quad$ Género: $\quad$ M $\quad \square \mathrm{F}$

La siguiente entrevista pretende conocer la apreciación del adulto mayor respecto a la experiencia vivida, de tal manera se pueda complementar la información recopilada, en las encuestas realizadas.

\section{Lista de Preguntas}

1. Dime tu nombre, edad, profesión u oficio.

Alberto Mendiola, 67, cajero bancario

2. ¿Sientes que a veces te tratan como a un niño pequeño?

No, más bien doy ordenes, cuando subo al carro, todos se paran para darme el asiento, pero no me gusta.

3. ¿Qué es lo que más echas de menos de tu juventud?

No haber aprovechado para ser deportista, pero la fiesta y el trago no me dejo. Me pedían para jugar $n$ clubs, pero no se pudo, es mi frustración

4. ¿Qué es lo mejor que se ha inventado desde que naciste?

La computadora. Tengo celular, tengo whatsapp. Pero lo uso como teléfono.

5. ¿Tiene familia?

$\mathrm{Si}$, estoy casado y tengo un hijo de 22 años.

6. ¿Con qué personas vives actualmente?

Mi esposa está en Italia hace un año y medio.

7. ¿Qué cosas dejan de preocuparte cuando te haces mayor? 
El sexo, ya no tengo la preocupación que tenía, la obsesión.

8. ¿Ha dejado de hacer algo que antes hacías?

El sexo, no está ella (esposa)

9. ¿Qué haces con tanto tiempo libre?

Bueno, ahora soy comerciante.

10. ¿Te sientes útil?

Claro que sí, tengo un hijo que estoy cuidando, el quiere trabajar, pero yo le digo que aun no.

11. ¿Tienes algún sueño por cumplir?

Quiero viajar a la habana cuba.

12. ¿Te sientes solo?

No, porque sociabilizo, no discrimino a las personas por la piel.

13. ¿En algún momento te has sentido discriminado por ser mayor?

Pues cuando estoy por ahí, que le dan el asiento y los viejos se molestan.

14. ¿Pertenece a algún club, grupo o casa para adulto mayor?

No, me pidieron, pero no. 
Anexo 11. Transcripción de las entrevistas a la comunidad

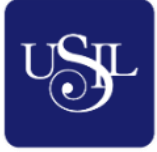
DAN IGNACIO
ENTREVISTA A LA COMUNIDAD CON LA FINALIDAD DE CONOCER LA OPINIÓN DE LAS PERSONAS SOBRE LA VEJEZ
Maestría en Diseño Gráfico
Fecha: 16/09/2019

Edad: 31 años
Entrevistador: Dayra Ita Sarrin

Género:

La siguiente entrevista pretende conocer la percepción de las personas de la comunidad respecto a la imagen de la vejez, de tal manera se pueda complementar la información recopilada, en las encuestas realizadas.

\section{Lista de Preguntas}

1. Para ti, ¿qué es la vejez?

La vejez para mi es la culminación del periodo de la etapa de la persona.

2. ¿Con qué término se refiere a una persona mayor?

Adulto mayor

3. ¿A qué edad considera usted que empieza la vejez?

Pienso que es de los 60 para adelante.

4. ¿Cómo se ve usted de mayor?

Me falta todavía, recién estoy en la base 3. 


\section{ENTREVISTA A LA COMUNIDAD CON LA FINALIDAD DE CONOCER LA OPINIÓN DE LAS PERSONAS SOBRE LA VEJEZ}

Fecha: 16/09/2019

Entrevistador: Dayra Ita Sarrin

Edad: 23 años

Género:

凶M

$\square \mathrm{F}$

La siguiente entrevista pretende conocer la percepción de las personas de la comunidad respecto a la imagen de la vejez, de tal manera se pueda complementar la información recopilada, en las encuestas realizadas.

\section{Lista de Preguntas}

1. Para ti, ¿qué es la vejez?

La vejez viene a ser cuando una persona ya está realizada, puede ser económicamente, profesionalmente y también en el ámbito familiar.

2. ¿Con qué término se refiere a una persona mayor?

Actualmente laboro en un área de atención al público, pero también soy ciudadanos de pie, por lo cual cuando veo a una persona mayor siempre le digo caballero o dama a las personas.

3. ¿A qué edad considera usted que empieza la vejez?

En mi opinión, pienso que es a los 65 años, porque a esa edad se podría decir que una persona ya está realizada.

4. ¿Cómo se ve usted de mayor?

Creo que, como todos con hijos, culminando el tema académico con una maestría o doctorado, y prácticamente realizado. 


\section{ENTREVISTA A LA COMUNIDAD CON LA FINALIDAD DE CONOCER LA OPINIÓN DE LAS PERSONAS SOBRE LA VEJEZ}

La siguiente entrevista pretende conocer la percepción de las personas de la comunidad respecto a la imagen de la vejez, de tal manera se pueda complementar la información recopilada, en las encuestas realizadas.

\section{Lista de Preguntas}

1. Para ti, ¿qué es la vejez?

Es la etapa de la vida, se supone que la persona tiene $\mathbf{4}$ fases, la niñez, la adolescencia, la adultez y la vejez, que es como la última etapa de la vida.

2. ¿Con qué término se refiere a una persona mayor?

Bueno lo típico es decirle abuelo o tío, aunque algunos lo llaman viejito, viejo o personas adultas $o$ adulto mayor, que ya son términos más técnicos.

3. ¿A qué edad considera usted que empieza la vejez?

En mi opinión la vejez comienza después de los 65 a 70 años, porque justamente es la edad en el que la Ley lo cesa del trabajo, porque ya estás en una edad que tienes que estar con mayor tranquilidad, aparecen algunas enfermedades,

4. ¿Cómo se ve usted de mayor?

Espero haber cumplimos con muchos sueños y muchas metas, haber viajo un montón, haber concebido muchas cosas, tener familia, nietos, con una casa propia, es más vivir en la playa. 


\section{ENTREVISTA A LA COMUNIDAD CON LA FINALIDAD DE CONOCER LA OPINIÓN DE LAS PERSONAS SOBRE LA VEJEZ

Fecha: 16/09/2019

Edad: 37 años
Género:

Entrevistador: Dayra Ita Sarrin
凶M

La siguiente entrevista pretende conocer la percepción de las personas de la comunidad respecto a la imagen de la vejez, de tal manera se pueda complementar la información recopilada, en las encuestas realizadas.

\section{Lista de Preguntas}

1. Para ti, ¿qué es la vejez?

La vejez para mí son los años acumulados de una persona durante el tiempo de su vida, que cuando toma mayor conciencia tiene mayores decisiones.

2. ¿Con qué término se refiere a una persona mayor?

Con usted.

3. ¿A qué edad considera usted que empieza la vejez?

A partir de los 60 años, porque antes de esa edad somos personas productivas. Después de los 60 pues ya viene la jubilación.

4. ¿Cómo se ve usted de mayor?

Realizado, con todas mis metas cumplidas. 


\section{ENTREVISTA A LA COMUNIDAD CON LA FINALIDAD DE CONOCER LA OPINIÓN DE LAS PERSONAS SOBRE LA VEJEZ

Fecha: 16/09/2019

Edad: 18 años
Género:

Entrevistador: Dayra Ita Sarrin

凶M

La siguiente entrevista pretende conocer la percepción de las personas de la comunidad respecto a la imagen de la vejez, de tal manera se pueda complementar la información recopilada, en las encuestas realizadas.

\section{Lista de Preguntas}

1. Para ti, ¿qué es la vejez?

Es cuando una persona está en al término de una edad muy avanzada y necesita el cuidado de otra persona.

2. ¿Con qué término se refiere a una persona mayor?

Cuando veo a una persona mayor, normalmente le digo tío, viejo, términos que la juventud utiliza para describir a las personas mayores.

3. ¿A qué edad considera usted que empieza la vejez?

Consideró que empieza a los 40 años

4. ¿Cómo se ve usted de mayor?

Me veo profesional, que no depende de alguien para vivir, como una persona que tiene su profesión con la que voy a sobrevivir. 


\section{ENTREVISTA A LA COMUNIDAD CON LA FINALIDAD DE CONOCER LA OPINIÓN DE LAS PERSONAS SOBRE LA VEJEZ

Fecha: 16/09/2019

Edad: 24 años
凶M
Entrevistador: Dayra Ita Sarrin

\section{Género:}

La siguiente entrevista pretende conocer la percepción de las personas de la comunidad respecto a la imagen de la vejez, de tal manera se pueda complementar la información recopilada, en las encuestas realizadas.

\section{Lista de Preguntas}

1. Para ti, ¿qué es la vejez?

Es el inicio y a su vez es el fin, de pasar de ser adultos a la tercera edad. Por lo cual es el inicio de algo totalmente diferente, en el cual uno descansa después de haber trabajado mucho tiempo.

2. ¿Con qué término se refiere a una persona mayor?

Señor, señora. Don o Doña

3. ¿A qué edad considera usted que empieza la vejez?

Alos 60 años

4. ¿Cómo se ve usted de mayor?

Me veo realizado, terminando mi segunda carrera y formando una empresa. 


\section{ENTREVISTA A LA COMUNIDAD CON LA FINALIDAD DE CONOCER LA OPINIÓN DE LAS PERSONAS SOBRE LA VEJEZ

Fecha: 16/09/2019

Edad: 19 años
Género:

Entrevistador: Dayra Ita Sarrin

凶M

La siguiente entrevista pretende conocer la percepción de las personas de la comunidad respecto a la imagen de la vejez, de tal manera se pueda complementar la información recopilada, en las encuestas realizadas.

\section{Lista de Preguntas}

1. Para ti, ¿qué es la vejez?

La vejez es una etapa donde la persona llega a un tema de madurez, un tema de conocimiento y también por ahí una mezcla de desgaste físico lamentablemente por un tema de la edad.

2. ¿Con qué término se refiere a una persona mayor?

Viejo, anciano también.

3. ¿A qué edad considera usted que empieza la vejez?

A partir de los 65, 70 años.

4. ¿Cómo se ve usted de mayor?

Según lo que voy viendo ahora, voy a llegar a una etapa en la que voy a sentir que eh logrado distintos objetivos, estaré en un lugar descansando, no estaré con una actividad muy activo, voy a estar más en casa, de repente con familiares e incluso con mascotas. 


\section{ENTREVISTA A LA COMUNIDAD CON LA FINALIDAD DE CONOCER LA OPINIÓN DE LAS PERSONAS SOBRE LA VEJEZ

Fecha: 16/09/2019

Edad: 58 años
Entrevistador: Dayra Ita Sarrin

Género: $M$ M

La siguiente entrevista pretende conocer la percepción de las personas de la comunidad respecto a la imagen de la vejez, de tal manera se pueda complementar la información recopilada, en las encuestas realizadas.

Lista de Preguntas

1. Para ti, ¿qué es la vejez?

Es un estado mental de cada persona.

2. ¿Con qué término se refiere a una persona mayor?

Adulto mayor

3. ¿A qué edad considera usted que empieza la vejez?

Eso es difícil de determinar. Yo creo que la vejez debe comenzar biológicamente a partir de los 65 años, pero a pesar de eso, como es un estado mental puedes tener una persona que tenga 40 años, pero que se sienta vieja a una persona de 65 años que se sienta sumamente joven.

4. ¿Cómo se ve usted de mayor?

Definitivamente mi cuerpo lo va a sentir, porque la energía no es la misma, pero mentalmente no creo sentirme muy diferente a como me siento ahora. 


\section{ENTREVISTA A LA COMUNIDAD CON LA FINALIDAD DE CONOCER LA OPINIÓN DE LAS PERSONAS SOBRE LA VEJEZ

Fecha: 16/09/2019

Edad: 38 años
Entrevistador: Dayra Ita Sarrin

Género: $M$ M

La siguiente entrevista pretende conocer la percepción de las personas de la comunidad respecto a la imagen de la vejez, de tal manera se pueda complementar la información recopilada, en las encuestas realizadas.

\section{Lista de Preguntas}

1. Para ti, ¿qué es la vejez?

Es una etapa de cambios, en el que las personas tienen más tiempo para poder hacer cosas que antes quizá no se podía hacer por múltiples actividades que hacemos.

2. ¿Con qué término se refiere a una persona mayor?

Dependiendo, si es alguien cercano, siempre les digo papitos. Y cuando son personas que recién conozco, les digo personas de la tercera edad.

3. ¿A qué edad considera usted que empieza la vejez?

Es a partir de los 60 años.

4. ¿Cómo se ve usted de mayor?

Habiendo realizado mis proyectos y viajando por el mundo, más tranquilla. 


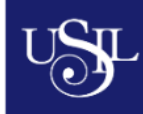
SAN IGNACIO DE LOYOLA

\section{ENTREVISTA A LA COMUNIDAD CON LA FINALIDAD DE CONOCER LA OPINIÓN DE LAS PERSONAS SOBRE LA VEJEZ}

Maestría en

Diseño Gráfico
Fecha: 16/09/2019

Edad: 40 años
Entrevistador: Dayra Ita Sarrin

Género: $\square \mathrm{M} \otimes \mathrm{F}$

La siguiente entrevista pretende conocer la percepción de las personas de la comunidad respecto a la imagen de la vejez, de tal manera se pueda complementar la información recopilada, en las encuestas realizadas.

\section{Lista de Preguntas}

1. Para ti, ¿qué es la vejez?

Todos llegamos a la vejez, para mi empieza en el momento en que sea abuela.

2. ¿Con qué término se refiere a una persona mayor?

Abuelito

3. ¿A qué edad considera usted que empieza la vejez?

A los 70

4. ¿Cómo se ve usted de mayor?

Me veo renegona, pero cariñosa sobre todo con mis nietos. 